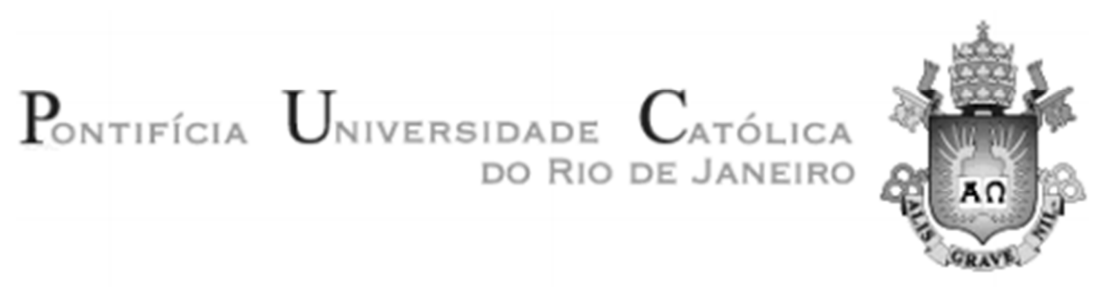

Arthur Figer

\title{
Entre gozo, angústia e desejo: articulações e paradoxos
}

\begin{abstract}
Dissertação de Mestrado
Dissertação apresentada como requisito parcial para obtenção do grau de Mestre pelo Programa de PósGraduação em Psicologia Clínica do Departamento de Psicologia da PUC-Rio.
\end{abstract}

Orientadora: Profa. Ana Maria de Toledo Piza Rudge

Rio de Janeiro

Março de 2013 


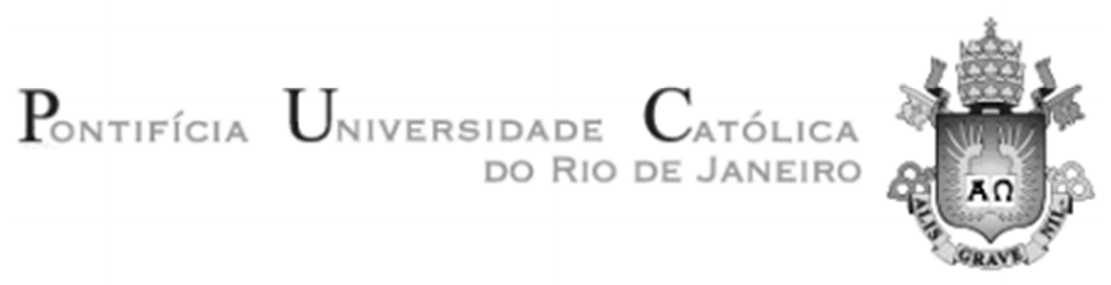

Arthur Figer

\title{
Entre gozo, angústia e desejo: articulações e paradoxos
}

\begin{abstract}
Dissertação apresentada como requisito parcial para obtenção do grau de Mestre pelo Programa de PósGraduação em Psicologia Clínica do Departamento de Psicologia do Centro de Teologia e Ciências Humanas da PUC-Rio. Aprovada pela Comissão Examinadora abaixo assinada.
\end{abstract}

\author{
Profa. Ana Maria de Toledo Piza Rudge \\ Orientadora \\ Departamento de Psicologia - PUC-Rio
}

Prof. Marcus André Vieira

Departamento de Psicologia - PUC-Rio

Prof. Eduardo Rozenthal

Instituto de Psicologia e Psicanálise - USU

Profa. Denise Berruezo Portinari Coordenadora Setorial de Pós-Graduação

e Pesquisa do Centro de Teologia

e Ciências Humanas - PUC-Rio

Rio de Janeiro, 27 de março de 2013 
Todos os direitos reservados. É proibida a reprodução total ou parcial do trabalho sem a autorização da universidade, do autor e da orientadora.

\section{Arthur Figer}

Graduou-se em Psicologia na USU (Universidade Santa Úrsula) em 2007. Cursou Administração de Empresas na UFRJ em 1997 (diploma cum laude) e concluiu pós-graduação em Engenharia Econômica e Administração Industrial, também na UFRJ, em 2000. É psicólogo clínico e psicanalista, membro associado da Sociedade de Psicanálise Iracy Doyle (SPID) e da Comissão Executiva da revista 'Tempo Psicanalítico'. Atua nas seguintes áreas de pesquisa: psicanálise, psicanálise e cultura e metapsicologia; e nos temas do gozo, desejo, pulsão de morte, supereu e angústia. Atende em consultório particular no centro do Rio de Janeiro.

\section{Ficha Catalográfica}

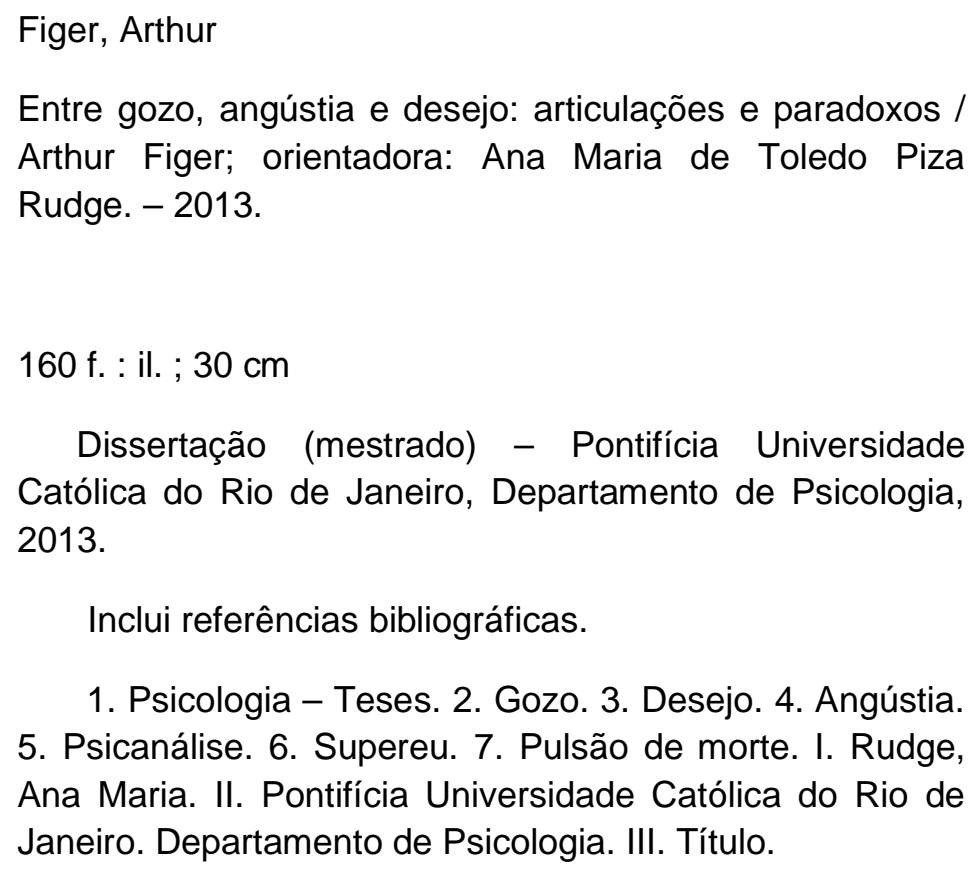


Para Carol, linda mulher, Theo e Guido, queridos filhos. Fontes inesgotáveis de inspiração. 


\section{Agradecimentos}

À CAPES e à PUC-Rio, pelos auxílios concedidos, sem os quais este trabalho não poderia ter sido realizado.

À Carolina linda, amada esposa, amiga e companheira, por todo o amor e carinho, por seus sorrisos e beijos, pela compreensão, apoio e paciência, e também pelas fundamentais cobranças e 'puxões de orelha'. Obrigado por tudo.

Aos meus queridos, amados e desejados filhos, Theo e Guido, imprescindíveis fontes de ânimo e inspiração nesta caminhada.

À minha mãe, Áurea, e meu pai, Silvio, por terem me proporcionado a base, os alicerces necessários para mais esta conquista.

Ao meu irmão Alex, grande amigo e companheiro de reflexões, estudos, lutas, alegrias, batucadas, vitórias e realizações.

Meu especial agradecimento à Professora Ana Maria Rudge, pela aposta no projeto que deu origem a este trabalho e pela orientação tranquila, acolhedora e, ao mesmo tempo, rigorosa. Minha gratidão por todas as oportunidades de aprendizado e crescimento que me foram proporcionadas.

Ao Professor Marcus André Vieira, por suas aulas, palestras e livros, sempre instigantes e inspiradores, terem despertado em mim o interesse pela obra de quem hoje considero um verdadeiro mestre, o psicanalista francês Jacques Lacan.

De maneira não menos entusiasmada, registro meu agradecimento ao Professor Eduardo Rozenthal, pela orientação e supervisão nos primeiros e fundamentais passos deste percurso.

Obrigado a todos vocês. 


\section{Resumo}

Figer, Arthur; Rudge, Ana Maria. Entre gozo, angústia e desejo: articulações e paradoxos. Rio de Janeiro, 2013. 160p. Dissertação de Mestrado - Departamento de Psicologia, Pontifícia Universidade Católica do Rio de Janeiro.

A presente dissertação busca esclarecer, principalmente a partir das teorias de Sigmund Freud e Jacques Lacan, a articulação de dois conceitos centrais da teoria psicanalítica, a saber: gozo e desejo. A partir desta investigação, serão propostos possíveis entrelaçamentos, convergências e correlações entre estes dois termos-chave da psicanálise, frequentemente tratados como opostos, divergentes e antagônicos, tanto na teoria como na clínica psicanalítica. $\mathrm{O}$ conceito de angústia também será abordado, uma vez que é situado por Jacques Lacan como 'termo intermediário entre o gozo e o desejo' (1962-63/2005, p. 193). As noções de um 'gozo a serviço do desejo' ou 'gozo produtivo' e de um 'gozo que estabiliza' serão algumas das articulações possíveis que serão propostas ao longo do trabalho. Considerando que o sujeito da psicanálise existe inserido na cultura, alguns fenômenos culturais serão observados e discutidos enquanto expressões tanto de gozo como de desejo e, por que não, de angústia. Pretende-se discutir também a importância do manejo, do acolhimento e da singularidade do gozo na clínica - 'diga-me como gozas e eu te direi quem és' - ou seja, de que maneira a forma única de cada um gozar, e a relação singular de cada sujeito com o gozo, pode contribuir para a direção do tratamento. Nossa bússola neste nebuloso e paradoxal percurso do desejo ao gozo serão as palavras de Miller: 'o gozo não mente' (2011, p. 195).

\section{Palavras-chave}

Gozo; desejo; angústia; psicanálise; supereu; pulsão de morte. 


\section{Abstract}

Figer, Arthur; Rudge, Ana Maria (Advisor). Between jouissance, anxiety and wish: connections and paradoxes. Rio de Janeiro, 2013. 160p. MSc. Dissertation - Departamento de Psicologia, Pontifícia Universidade Católica do Rio de Janeiro.

This dissertation seeks to clarify, mainly in the theories of Sigmund Freud and Jacques Lacan, the articulation of two central concepts of psychoanalytic theory, namely jouissance and desire. From this research, possible interlacements, convergences and correlations will be proposed between these two key terms of psychoanalysis, often treated as opposites, divergent and antagonistic, both in theory and in clinical psychoanalysis. The concept of anxiety will also be addressed, since it is located by Jacques Lacan as a 'middle term between jouissance and desire' (1962-63/2005, p. 193). The notions of a 'jouissance in the service of desire' or 'productive jouissance' and a 'jouissance that stabilizes' are some of the proposals that will be presented along the text. Once the subject of psychoanalysis is inserted into the culture, some cultural phenomena are observed and discussed throughout the work as expressions of both jouissance and desire and, why not, of anxiety. We also intend to discuss handling, care and the importance of the singularity of jouissance in the psychoanalytic clinic - 'tell me how you enjoy (jouis) and I'll tell you who you are' - in other words, how the unique mode of jouissance and the unique relationship established by each subject with jouissance, can contribute to the direction of the treatment. Our compass in this paradoxical and nebulous course from desire to jouissance will be Miller's words: 'the jouissance doesn't lie' (2011, p. 195).

\section{Keywords}

Jouissance; wish; anxiety; psychoanalysis; superego; death drive. 


\section{Sumário}

1. Introdução

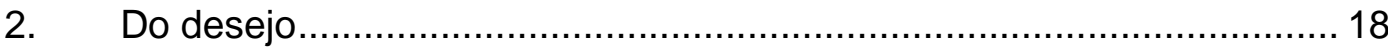

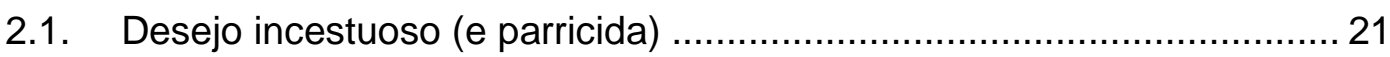

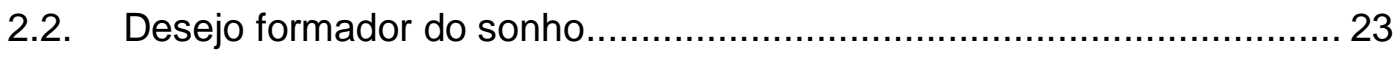

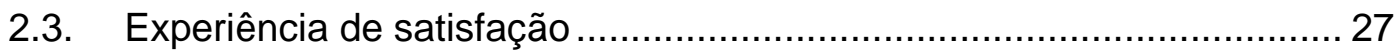

2.4. A concepção lacaniana do desejo .................................................. 29

2.5. Desejo, necessidade e demanda................................................. 30

2.6. Desejo como desejo do Outro ........................................................ 33

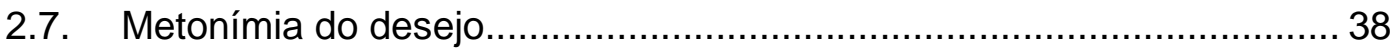

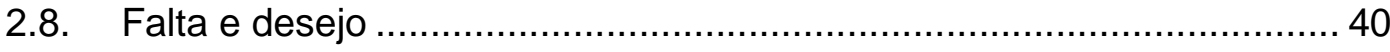

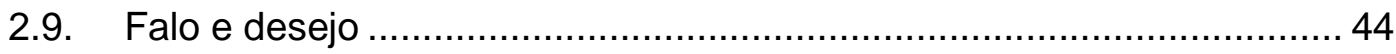

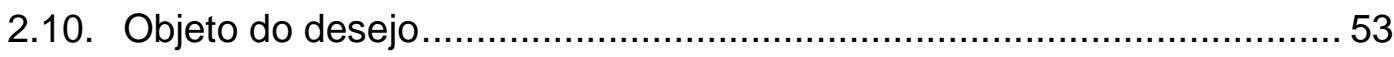

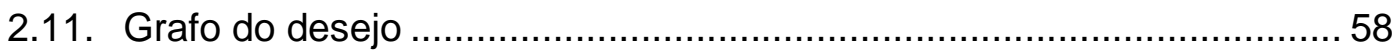

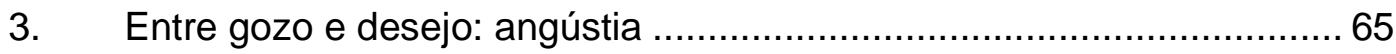

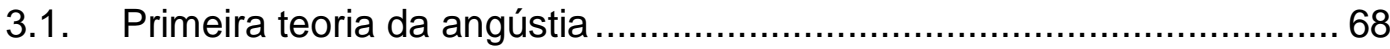

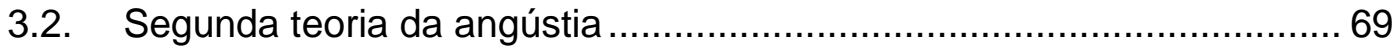

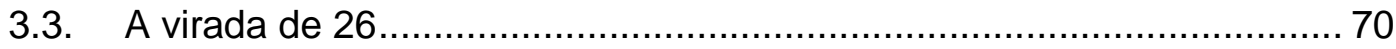

3.4. Meio-termo entre gozo e desejo …........................................... 73

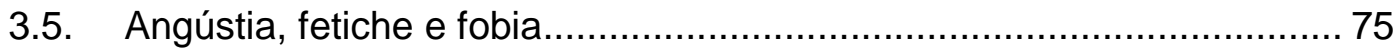

3.6. Além da angústia de castração ............................................... 78

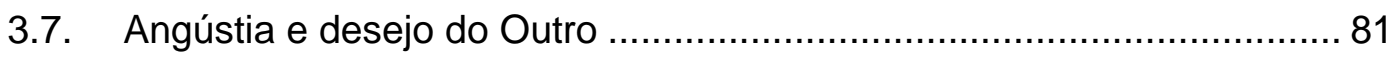

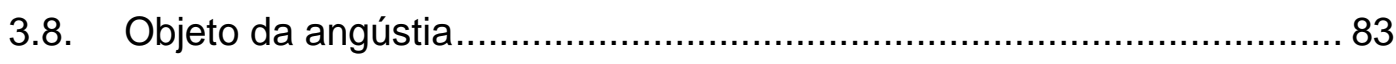




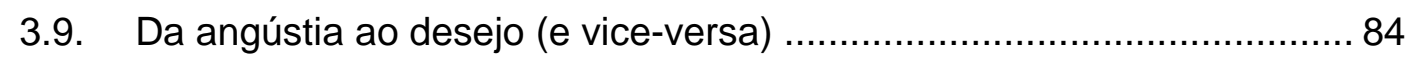

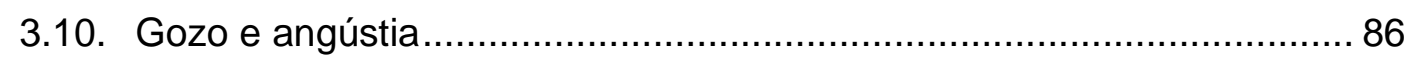

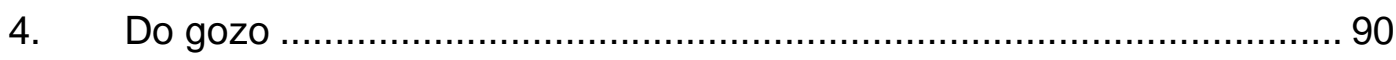

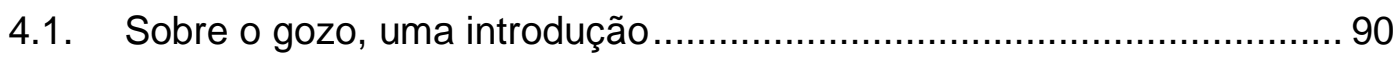

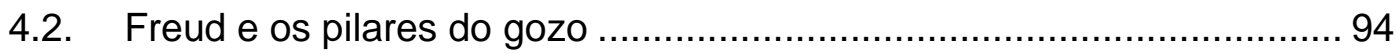

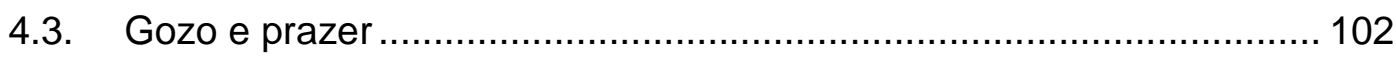

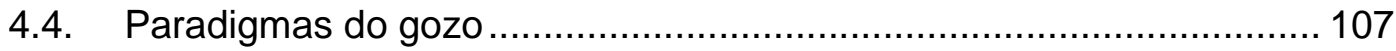

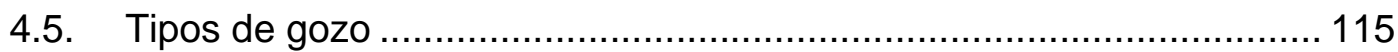

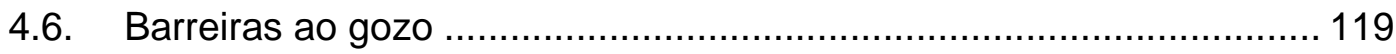

5. Gozo, angústia e desejo na cultura ....................................... 124

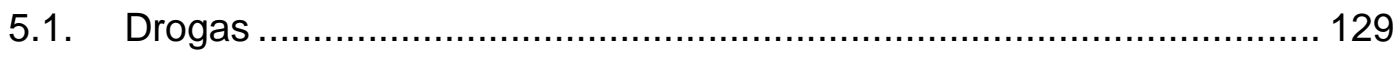

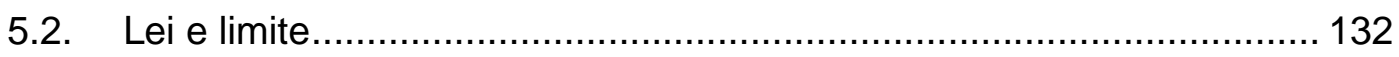

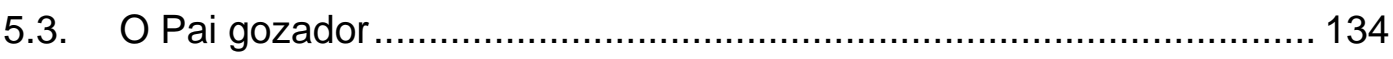

6. Gozo, angústia e desejo na clínica ........................................ 136

6.1. Desejo na clínica ................................................................... 136

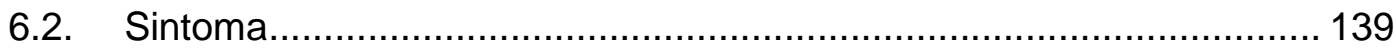

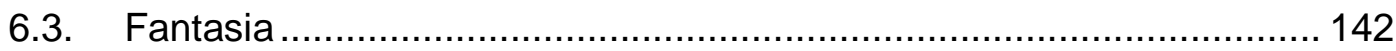

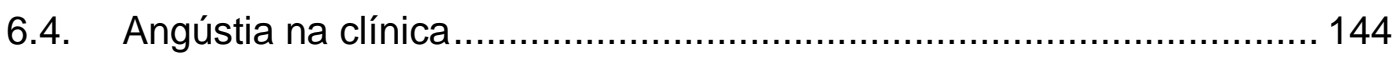

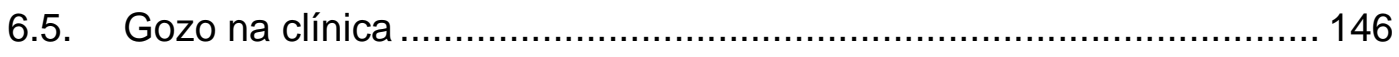

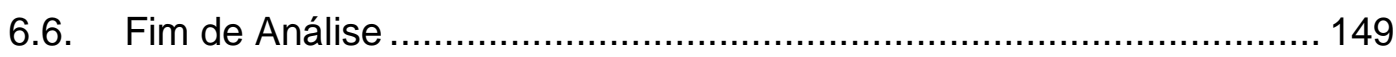

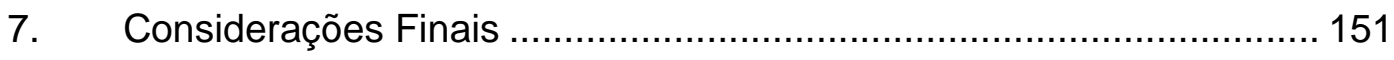

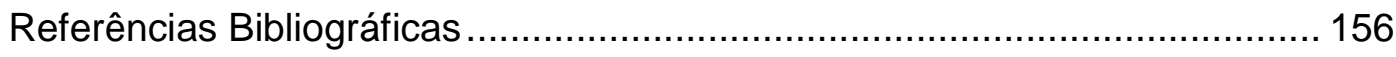


'Aqui, trata-se de atacar, evidentemente, algo que é da ordem da relação do desejo com o gozo'.

J. Lacan, a angústia 


\section{Introdução}

Os conceitos de gozo e desejo vêm ocupando lugar de relevância, tanto na teoria como na clínica psicanalíticas. Há importantes autores contemporâneos que têm dedicado tempo e atenção a estes dois conceitos. "Entre Desejo e Gozo" (2011), por exemplo, foi o subtítulo escolhido pelo psicanalista francês JacquesAlain Miller, herdeiro intelectual de Lacan, para seu livro recentemente publicado no Brasil, no qual faz uma análise de textos contidos na obra do mestre francês, tendo como fio condutor estes dois conceitos fundamentais da psicanálise. $\mathrm{O}$ importante conceito psicanalítico de angústia - 'único afeto que não engana', segundo Lacan - também será investigado, enquanto termo intermediário entre gozo e desejo.

Os objetivos principais do presente trabalho podem ser enunciados conforme segue:

a) Pesquisar os estatutos dos conceitos de gozo, desejo e angústia, principalmente nas obras de Sigmund Freud e Jacques Lacan, visando rastrear as origens, caminhos de construção, revisão e desenvolvimento destes três conceitos fundamentais da psicanálise;

b) Construir possíveis articulações, correlações e entrelaçamentos entre os conceitos psicanalíticos de gozo, desejo e angústia, e destes com outros conceitos também relevantes dentro da teoria psicanalítica;

c) Discutir alguns fenômenos culturais sob a ótica da psicanálise, principalmente a partir dos três conceitos-chave desta investigação: gozo, angústia e desejo.

d) Propor formas de (re)pensar a clínica psicanalítica, a partir das articulações e proposições teóricas construídas ao longo do trabalho.

Uma vez que se trata de pesquisa primordialmente teórica, a revisão bibliográfica foi o principal instrumento de investigação utilizado nesta produção. Não obstante, minha experiência clínica, certamente, teve forte repercussão na 
escolha tanto do tema como das questões levantadas e discutidas ao longo do trabalho. As obras de autores mais atuais da psicanálise, que vêm contribuindo e enriquecendo as teorias freudiana e lacaniana de gozo e desejo, também foram utilizadas na pesquisa. Dentre estes autores, podemos destacar Ana Maria Rudge, Jacques-Alain Miller, Marcus André Vieira, Néstor Braunstein e Patrick Valas, como referências utilizadas para o aprofundamento dos assuntos estudados. Desta forma, almejamos estabelecer conexões e articulações inovadoras entre os autores e teorias pesquisadas, possibilitando, assim, a proposição de novas e produtivas questões.

Gozo e desejo são termos frequentemente empregados na literatura psicanalítica, seja em textos que abordam aspectos mais relativos à teoria, seja em narrativas de casos clínicos. Com quase a mesma frequência, porém, tais conceitos são tratados como divergentes, opostos e antagônicos. Para além desta visão maniqueísta que predomina, nossa proposta é a de investigar, a partir, principalmente, das teorias de Sigmund Freud e Jacques Lacan, as possibilidades de convergência, articulação e entrelaçamento destes dois conceitos-chave da psicanálise, buscando novas propostas e contribuições para o avanço da construção do conhecimento psicanalítico.

No decorrer do trabalho, buscamos construir e propor questões paradoxais, como por exemplo: pode-se falar em gozo produtivo? O gozo pode estar a serviço do desejo? A pulsão de morte poderia estar relacionada à criação? Há um limite para o gozo? Adiantando, uma das teses a serem propostas é a ideia do gozo como impulsionador (facilitador) da produção, da criação, e, porque não, do desejo aquilo que propomos chamar de face produtiva do gozo, ou simplesmente, gozo produtivo. Será levantada também a questão da importância do manejo e da singularidade do gozo na clínica, que pode ser traduzida a partir da seguinte proposição - 'diga-me como gozas e eu te direi quem és'. Com efeito, nossa proposta é a de que o gozo não deveria ser simplesmente escutado na clínica, ele deve ser acolhido. Conforme Miller (2011) nos ensina: 'o gozo não mente' (2011, p. 195).

A questão dos paradoxos é tão presente na teoria lacaniana do gozo que mereceu pelo menos duas 'menções honrosas': ao dar nome a um conjunto de 
capítulos do seminário 7 de Jacques Lacan ('La Etica del Psicoanálisis') e ao ser escolhido por Serge Cottet como tema de seus seminários no Brasil, nos anos de 1988 e 1989, que, posteriormente, viraram um livro de mesmo título (" $O$ paradoxo do gozo"). Lacan, mostrando-se intrigado com tais fenômenos contraditórios quando se trata de gozo e supereu, levanta a seguinte questão:

Vamos perguntar-nos o que pode significar, nessa perspectiva, o fato de o sujeito humano ser capaz de se apropriar das condições que lhe são impostas em seu mundo, como se essas condições fossem feitas para ele, e de se satisfazer com elas. (Lacan, 1957-58/1999, p. 262)

Situado por Jacques Lacan como 'termo intermediário entre o gozo e o desejo' (1962-63/2005, p. 193), o conceito de angústia também será abordado como este meio-termo, fazendo exatamente esta 'ponte-de-ligação', esta 'sutura' entre os capítulos do desejo e do gozo. Elevada por Lacan à categoria de 'único afeto que não engana' (1962-63/2005, p. 88), a angústia apresenta-se como uma espécie de 'estranheza' experimentada pelo sujeito diante do desejo do Outro. Que objeto (a) eu sou para este desejo (do Outro)? Este é o enigma angustiante proposto por Lacan com seus 'Che vuoi?' e 'Que me veut-il?' - 'Que queres?' 'Que quer ele de mim?'

Os capítulos estão organizados de forma a possibilitar o cumprimento do percurso teórico traçado, ou seja, uma ampla investigação dos conceitos de gozo, angústia e desejo, tanto na teoria e na clínica psicanalíticas quanto na cultura, e o cotejamento destes com outros conceitos também de reconhecida importância. Os três primeiros capítulos são dedicados à investigação dos estatutos dos conceitos de gozo, angústia e desejo nas obras de Freud e Lacan. A proposta é realizar uma apresentação didática inicial destes três conceitos dentro da teoria psicanalítica, rastreando suas origens, desde as primeiras definições e tentativas de teorização, passando pelas transformações sofridas ao longo do tempo, até chegarmos às contribuições e ( $r e$ )formulações propostas por autores mais atuais.

No primeiro capítulo, sobre o desejo, empreendemos um percurso de Freud a Lacan no qual buscamos marcar as principais etapas e reviravoltas da construção deste importante conceito psicanalítico, que seria, segundo Lacan, "função central 
em toda experiência humana" (1954-55/2010, p. 302). Iniciamos com a proposição freudiana de que o sonho é a realização de um desejo, passamos pelos desejos incestuosos e parricidas, pela experiência de satisfação e, finalmente avançamos em direção às importantes contribuições de Lacan para a teoria psicanalítica do desejo.

Ao postular que o campo psicanalítico é fundado na fala e na linguagem, e que o inconsciente se constitui na e pela linguagem, o psicanalista francês Jacques Lacan sublinha a importância do registro simbólico como aquele fundante do sujeito do desejo. Destacando a importância do desejo tanto para a teoria quanto para a clínica, Garcia-Roza (2000) vai dizer o seguinte:

\begin{abstract}
Afirmar que no centro da teoria e da prática psicanalíticas está situado o desejo não constitui, hoje em dia, uma afirmação original. J. Lacan vem dizendo isso há longo tempo e, no final das contas, não está fazendo mais do que reler para ouvidos impregnados de reducionismos a palavra do mestre. (Garcia-Roza, 2000, p. 139)
\end{abstract}

Posicionado, não por acaso, entre os capítulos do gozo e do desejo, o segundo capítulo é dedicado ao conceito de angústia, 'único afeto que não engana', localizado por Lacan justamente aí, no meio-termo entre gozo e desejo. Neste capítulo discutiremos as duas teorias freudianas da angústia, começando pela ideia de que a angústia seria simplesmente resultado da transformação de certa 'energia sexual somática' que não teria sido devidamente escoada. Tal fenômeno resultaria naqueles quadros que Freud denominou 'neuroses atuais', ou seja, 'neurastenia' e 'neurose de angústia'. A segunda teoria freudiana da angústia abarca a concepção de que a angústia adviria a partir do recalque, uma vez que desta operação psíquica decorreria um acúmulo de libido 'solta', ou seja, energia psíquica desligada de suas representações. Em seguida, apresentamos o movimento teórico conhecido como "virada de 1926" no qual a angústia passa a ser pensada como forma de reação a uma situação traumática.

Faremos também uma articulação entre os conceitos de angústia, fetiche e fobia, assinalando a ideia lacaniana de que tanto o fetiche, quanto a fobia podem ser encarados como "proteções" contra a angústia. Na letra de Lacan, temos o seguinte: "o fetiche desempenha, na teoria analítica, uma função de proteção 
contra a angústia e, coisa curiosa, a mesma angústia, isto é, a angústia de castração" (Lacan, 1956-57/1995, p. 22). Iremos ainda, com Lacan, para "Além da angústia de castração", momento em que a angústia é concebida pelo mestre francês não como falta, mas como falta de falta ('le manque vient à manquer' ${ }^{1}$ ). Em linha com nossa intenção de apresentar os conceitos, sempre que possível, de forma contígua, nos propomos a articular ainda neste capítulo o conceito de angústia com os conceitos de gozo e desejo, a partir de diversas perspectivas teóricas.

No terceiro capítulo trataremos do gozo. Aquele, "cuja falta tornaria vão o universo", segundo Lacan (1966/1998, p. 834). Começaremos por uma introdução ao conceito de gozo, articulando-o aos conceitos de usufruto e prazer. Em seguida, buscaremos na fonte freudiana os principais conceitos utilizados por Lacan para a construção do seu conceito de gozo. Encontramos na 'pulsão de morte', na 'compulsão à repetição' e no 'masoquismo' freudianos as principais bases teóricas para a concepção do conceito de gozo por Lacan. A ideia de parcialidade do gozo, parcialidade advinda da perda de um gozo absoluto, será abordada a partir de suas possíveis articulações com o fenômeno da compulsão à repetição, que remete a uma busca incessante pela totalidade.

Discutiremos também, ao longo deste capítulo, o importante texto de Miller intitulado "Os seis paradigmas do gozo" (2012), no qual o autor realiza uma sistematização didática dos movimentos teóricos que marcaram o desenvolvimento do conceito de gozo por Lacan. Conceito permeado por paradoxos, abordaremos neste capítulo os principais deles relacionados ao gozo, avançando, ao invés de recuar, diante das aparentes contradições teóricas encontradas. Como exemplo, podemos citar a ideia de que a renúncia ao gozo alimenta o gozo da renúncia (Vieira, 2008) e a proposição lacaniana que sustenta que o gozo precisa da lei para transgredi-la. Sem lei, ao contrário do que se tende a pensar, há outra coisa, não gozo. Serão abordadas ainda as chamadas "modalidades de gozo" e as características de cada uma. Gozo do ser, gozo fálico e gozo do Outro são as três modalidades consideradas por Braunstein (2007) e que serão discutidas nesta parte da pesquisa. A questão da relação do gozo com a

\footnotetext{
${ }^{1}$ A falta vem a faltar.
} 
sexualidade - em suas diferentes nuances para o homem e para a mulher - também será considerada no decorrer desta parte do trabalho. Outro assunto importante quando se trata de gozo, que também fará parte das discussões deste capítulo, é o que diz respeito às "barreiras ao gozo". Como refrear algo tão poderoso cuja natureza é fundamentalmente transgressiva? Isso é o que nos propomos a refletir.

O quarto capítulo é dedicado à investigação de alguns fenômenos culturais em suas possíveis articulações com os conceitos psicanalíticos tema deste trabalho. O que chamamos de 'sociedade do excesso' ou 'sociedade do gozo' ilustra o fenômeno atual de um não querer saber da falta e, por consequência, certa dificuldade em se estabelecer limites, em lidar com a lei. Este mesmo excesso é também uma das características mais marcantes do conceito psicanalítico de gozo - pura expressão de um excedente com o qual o sujeito é impelido a lidar. Trabalhar o conceito de limite torna-se fundamental quando abordamos o tema do gozo e os mecanismos utilizados pelo homem para evitar o sofrimento e o mal-estar. Na sociedade atual marcada pela ausência de referências e, consequentemente, pela dificuldade em se estabelecer limites, torna-se urgente discutir questões como: Quando basta? Há um limite consensual ou ele é absolutamente singular? É possível impor restrições ao gozo? A morte é o limite? O ilimitado é sempre angustiante. Articulando morte e limite, Garcia-Roza diz o seguinte: "a morte como limite é o muro de Sartre, o que não pode ser experimentado porque assinala o fim da própria experiência - pelo menos da experiência humana" (1986, p. 72).

Uma vez que teoria e prática clínica não podem andar separadas, no quinto capítulo pretende-se pensar a clínica psicanalítica a partir das questões teóricas e articulações construídas ao longo do trabalho. O percurso de uma análise - do gozo ao desejo, e vice-versa - implica em propiciar ao analisando o reconhecimento da verdade sobre seu desejo, o que só é possível no domínio simbólico da linguagem, quando este é articulado na fala. Enquanto formação de compromisso entre forças recalcadoras e forças recalcadas, o sintoma traz em si uma mensagem cifrada que pede decifração, leitura e interpretação - disfarce de um desejo inconsciente que por ter sido rejeitado e excluído só pode se apresentar através de uma máscara. Neste capítulo, buscaremos esclarecer também a relação 
existente entre as formações sintomáticas e o conceito psicanalítico de fantasia. Veremos também a importância da angústia para o processo de análise, funcionando como uma espécie de 'bússola', marcando assim os movimentos de passagem do sujeito do gozo ao desejo, e vice-versa. A tarefa de modulação da angústia é, segundo Lacan, um dos principais desafios dos analistas - aquilo que os poria à prova a todo instante. O gozo, por sua vez, será tratado na clínica como potência criativa que, ao invés de ser combatida, deveria ser acolhida, de forma a propiciar a criação/gestação conjunta analista-analisando de novos modos de gozo, de forma que este possa estar em contiguidade e não em oposição ao desejo. Aumentar a repressão a este gozo que é da ordem do ilimitado tem-se demonstrado ineficaz, pois como bem observa Vieira (2008, p. 90) "sempre se pode fechar a boate, mas a festa se prolonga em bares, calçadas, na casa de alguém, e assim por diante". De que recursos o analista disporia, enfim, para lidar com isso que é da ordem do ilimitado e do indizível? É o que buscaremos discutir ao longo deste capítulo. 


\section{Do desejo}

Sendo o mundo freudiano um universo de desejo e de gozo, devemos precisar, antes de tudo, como a psicanálise define o desejo. (Valas, 2001, p. 11)

$\mathrm{Na}$ teoria freudiana, a ideia de desejo é, antes de mais nada, a de um desejo ao mesmo tempo inconsciente e sexual. Para Freud, o desejo (inconsciente) teria como força propulsora a sexualidade, que por sua vez seria alimentada pelo desejo incestuoso. Sobre estas duas características marcantes do conceito psicanalítico de desejo - inconsciente e sexual -, Lacan diz o seguinte: "os motivos do inconsciente se limitam - ponto sobre o qual Freud se pronunciou desde o começo e que nunca alterou - ao desejo sexual" (Lacan, 1966/1998, p. 433).

Se levarmos em consideração as raízes inconscientes e sexuais do desejo, tanto o termo 'Wunsch', em alemão, como 'Wish', em inglês, carecem justamente do aspecto sexual, tão marcante na concepção psicanalítica do desejo. A palavra 'Désir' é o termo utilizado nas edições francesas da obra de Freud para traduzir o vocábulo alemão 'Wunsch', que, por sua vez, é traduzido como 'Wish' por James Strachey na Standard Edition inglesa. Desta forma, os tradutores da obra de Lacan para o idioma inglês são confrontados com a questão de traduzir 'Désir' como 'Wish', que seria mais próximo do termo alemão 'Wunsch' de Freud, ou optar pelo termo inglês 'Desire', com significado mais parecido com a palavra francesa 'Désir', porém, perdendo-se assim a alusão ao termo original utilizado por Freud. É interessante observar que todos os tradutores de Lacan para a língua inglesa optaram pelo termo 'Desire', uma vez que este vocábulo inglês transmite, assim como o original francês, a ideia de uma força contínua vinculada ao aspecto sexual, atributos estes essenciais para o conceito lacaniano (e freudiano) de desejo. Repetimos: não é a qualquer tipo de desejo que Freud e Lacan se referem quando falam de desejo, mas sempre ao desejo inconsciente, de raízes sexuais. 
Acompanhemos Lacan (1954-55/2010) na seguinte passagem esclarecedora sobre o tema:

Está bem, na criança não há elaboração de desejo, durante o dia ela tem vontade de ter cerejas e, de noite, sonha com cerejas. Só que, nem por isto Freud deixa de salientar que, até mesmo nesta etapa infantil, o desejo do sonho, como o do sintoma, é um desejo sexual. Disto ele nunca vai abrir mão. (Lacan, 1954-55/2010, p. 305)

Apesar desta base em comum, a concepção lacaniana do desejo ('Désir') é muito diferente do conceito freudiano ('Wunsch'). Para Freud, um desejo inconsciente busca realização, por exemplo, em sonhos, evocando sinais ou traços de memória amarrados às experiências de satisfação constitutivas do sujeito. É o sonho visto por Freud como realização de um desejo recalcado. O conceito de fantasia, para a psicanálise, envolve uma cena imaginária na qual o sujeito que está fantasiando é frequentemente o protagonista e que representa a realização de um desejo inconsciente de maneira distorcida, assim como no sonho. Na teoria freudiana, o desejo é sempre organizado em torno de uma fantasia, e para qualquer sujeito particular, o desejo é sempre marcado por características irremediavelmente singulares. Articulando sonho, desejo e fantasia, Rudge (1999) escreve o seguinte:

A fórmula freudiana é que o sonho é realização de desejo (Wunscherfüllung), representação do desejo como realizado e, portanto, fantasia. Sabemos que, para Freud, toda a fantasia é realização de desejo. Seja a fantasia diurna (os devaneios), a fantasia inconsciente ou a fantasia onírica, é lá, numa cena fantasmática, onde se realiza o desejo. (Rudge, 1999, p. 66)

A concepção freudiana do desejo refere-se, sobretudo, a desejos inconscientes, ligados a símbolos infantis indestrutíveis, organizados como fantasia. A análise da histeria por Freud demonstrou como as histéricas tomam sua imaginação pela realidade, e, mais importante, como elas traduzem - de acordo com leis específicas de transposição - o seu desejo em realidade. Seu próprio desejo de seduzir o pai é traduzido, de forma inversa, em uma cena real de sedução pelo pai. 
Lacan segue Freud ao distinguir o desejo da mera necessidade ou da demanda, que podem ser satisfeitas, mesmo que temporariamente, pela aquisição ou consumo de determinado objeto. Porém, enquanto Freud busca estabelecer a relação entre desejo e satisfação, propondo que a satisfação deve submeter-se às distorções da censura, a releitura lacaniana corta em definitivo qualquer relação direta entre desejo e satisfação. Esta impossibilidade de satisfação está presente, inclusive, na origem etimológica da palavra "desejo", formada a partir dos vocábulos latinos 'de' (privação) + 'sidus' (estrela), que nos remete à ideia de uma impossibilidade; "imposibilidade de alcançar e possuir uma estrela do firmamento", diz Zimerman (2001, p. 102).

Segundo Roudinesco (1998, p. 146), enquanto nos idiomas francês e espanhol existe apenas uma palavra para designar a ideia de desejo ('Désir'/'Deseo'), na língua alemã há três: 'Begierde', 'Lust' e 'Wunsch'. Ao optar pelo termo 'Wunsch', Freud despreza a tradição filosófica de consciência e de sujeito de Hegel ('Begierde') e opta por uma significação mais voltada para as ideias de 'voto' ou 'anseio'. Nesse sentido, desejo para Freud seria a realização de um anseio ou voto inconsciente, carecendo, portanto das ideias de concupiscência/cobiça ou de reconhecimento de si através do outro e do outro através de si mesmo, presentes na concepção filosófica. Dentre os sucessores de Freud, Jacques Lacan foi o único a conceituar o desejo a partir da tradição filosófica, fazendo dele a expressão de uma cobiça ou apetite fora de qualquer possibilidade de realização. De acordo com Roudinesco (1998), dentro desta concepção lacaniana de desejo ('Désir'), utiliza-se, em alemão, a palavra 'Begierde' e em inglês a palavra 'Desire'. Garcia-Roza (2002) diz que o significante alemão utilizado por Freud ('Wunsch') está mais próximo do significado 'aspiração', enquanto o termo 'desejo' (assim como désir em francês) remeteria ao movimento de concupiscência ou cobiça, aproximando-o do alemão 'Begierde' ou ainda 'Lust' (Garcia-Roza, 2002, p. 181).

O terceiro termo em alemão que, segundo Roudinesco (1998), também abarcaria a noção de desejo - 'Lust' - era empregado por Freud no sentido de 'paixão' ou 'pendor', sendo utilizado também para nomear seu "princípio de prazer" ('lustprinzip'). Acompanhemos Rudge (1998) em uma interessante 
definição que articula prazer, desejo e fantasia em Freud: "A corrente que se inicia no desprazer e tem o prazer como finalidade é o que Freud chamará desejo. O primeiro desejo foi a alucinação da satisfação." (Rudge, 1998, p. 21).

É importante fazermos aqui, desde já, uma distinção entre desejo e pulsão. Embora ambos pertençam ao campo do Outro e sejam representados por forças constantes que pressionam - para se satisfazerem, no caso da pulsão, e para se tornar consciente, no caso do desejo - o desejo é um enquanto as pulsões são muitas. Em outras palavras, as pulsões seriam manifestações parciais de uma única força chamada desejo.

\subsection{Desejo incestuoso (e parricida)}

Um dia, na nossa mais remota infância, tramamos cometer os dois maiores crimes de que alguém pode ser acusado: o parricídio e o incesto. (Garcia-Roza, 2002, p. 9)

Com esta afirmação sucinta e esclarecedora, Garcia-Roza (2002) nos apresenta os dois desejos primordiais e intimamente relacionados, que nos acompanham desde a mais tenra infância e pelo resto de nossas vidas: os desejos de cometer tanto o incesto como o parricídio. Em relação a desejos tão repugnantes e condenáveis como estes, não resta outra alternativa ao eu senão proteger-se, afastando tais ideias perturbadoras da consciência, através do mecanismo do recalque. Eis o que permeia a busca do neurótico, cifrada em seus sintomas: proteger-se de seu próprio desejo. O 'desejo de não desejar', segundo Lacan (1964), representa precisamente esta proteção contra o próprio desejo, uma fase defensiva, na qual o desejo se torna idêntico a não querer desejar.

Ocorre que tais desejos permanecem, beneficiando-se da atemporalidade característica do inconsciente, ativos e afetando nossa vida consciente indiretamente e de forma distorcida, seja através de sonhos, atos falhos, chistes ou sintomas. Daí o forte apego aos sintomas que, por um lado, servem para proteger 
o sujeito de seu desejo, e, por outro lado, permitem certa satisfação do mesmo. Entretanto, eles atrapalham, quando não paralisam, a vida do sujeito. Para libertarse desta "prisão" e entrar na dialética do desejo é preciso que haja uma espécie de revolta, uma insubordinação do sujeito na sua relação com a autoridade, as instituições, as leis e os princípios estabelecidos. A esse respeito, Valas (2001) diz o seguinte:

Em sua imensa maioria, os seres humanos preferem submeter-se aos imperativos obscenos e ferozes do Supereu a correr o risco de entrar na dialética do desejo, que supõe uma subversão do sujeito na sua relação com a Lei. (Valas, 2001, p. 43)

Para começar, o infante deseja o 'objeto primordial' ou 'Mãe'. Ocorre que para entrar em uma relação de desejo com o 'objeto primordial', o sujeito precisa identificar-se com a imagem que este Outro primordial espera dele. Para Lacan, o campo inicial da experiência da criança é, portanto, intrinsecamente instável, oscilando em uma dialética que inevitavelmente confunde objetos de desejo com objetos de identificação.

O desejo incestuoso, chamado por Lacan de "desejo essencial", carrega consigo a marca de uma falta, de uma impossibilidade - a impossibilidade do incesto. Diz Lacan (1959-60/2009):

Es importante que haya habido un hombre que, en un momento determinado de la historia, se haya levantado para decir: Este (el deseo del incesto) es el deseo essencial.2 (Lacan, 1959-60/2009, p. 84)

A realização desse desejo essencial é gozo, ou seja, uma das abordagens possíveis do gozo seria exatamente pelo viés da realização do desejo. O desejo incestuoso não pode se concretizar nunca, sob pena do sujeito entrar na psicose e dela nunca mais sair. O pai precisa intervir para que este desejo nunca se realize; para que permaneça insatisfeito, para que o sujeito possa constituir-se como tal, ganhando acesso ao campo do desejo e da linguagem. É justamente esta intervenção paterna que suscita os sentimentos ambivalentes da criança em

\footnotetext{
${ }^{2}$ É importante que tenha havido um homem que, em um determinado momento da história, se tenha levantado para dizer: Este (o desejo incestuoso) é o desejo essencial.
} 
relação ao pai. Amor e ódio são as marcas desta relação. A agressividade da criança é dirigida à figura paterna justamente por esta atuar de forma a impedir a realização do desejo essencial do incesto. Surge assim o desejo parricida.

Tanto o pai morto (parricídio) quanto a consumação da relação sexual com a mãe (incesto) estariam inscritos, portanto, no campo do gozo. Está aí delineada a ideia do gozo enquanto realização do desejo.

\subsection{Desejo formador do sonho}

A elucidação mais clara do conceito de desejo em Freud está em sua teoria dos sonhos. O desejo, segundo Freud, seria aquilo que se realiza no modo alucinatório, primordialmente nos sonhos. "Nossa teoria dos sonhos encara os desejos originários do infantil como a força propulsora indispensável para a formação dos sonhos." (Freud, 1900/1996, p. 616). Sobre o emblemático sonho de Irma, Freud (1900/1996) argumenta que seu conteúdo foi a realização de um desejo, e seu motivo foi um desejo. Em outra passagem esclarecedora da relação dos sonhos com o desejo, o inventor da psicanálise diz o seguinte:

Não se devem assemelhar os sonhos aos sons desregulados que saem de um instrumento musical atingido pelo golpe de alguma força externa, e não tocado pela mão de um instrumentista; eles não são destituídos de sentido, não são absurdos; não implicam que uma parcela de nossa reserva de representações esteja adormecida enquanto outra começa a despertar. Pelo contrário, são fenômenos psíquicos de inteira validade - realizações de desejos; podem ser inseridos na cadeia dos atos mentais inteligíveis de vigília; são produzidos por uma atividade mental altamente complexa. (Freud, 1900/1996, p. 157).

Garcia-Roza (2002) destaca, na obra de Freud, três possíveis origens para os desejos que se realizam nos sonhos. São elas:

1) Desejos despertados durante o dia que, por motivos puramente exteriores, não foram satisfeitos. Trata-se aqui de desejos provenientes do sistema Pré-consciente/Consciente (Pcs/Cs); 
2) Desejos despertados durante o dia que, por provocarem certo repúdio, por qualquer razão, foram então suprimidos (não recalcados) através de uma operação do sistema Pcs/Cs que exclui determinado conteúdo da consciência, sem que este passe a pertencer ao Inconsciente (Ics) recalcado; e

3) Pode ser ainda um desejo que não guarde nenhuma relação com a vida diurna atual, tornando-se ativo somente durante o sono. Sua origem, neste caso, é o inconsciente, mais especificamente, o inconsciente recalcado.

A estas três fontes, segundo o autor, Freud ainda vai acrescentar uma quarta, que seriam as moções de desejo que surgem durante a noite, a partir de estímulos físicos como sede ou necessidades sexuais. Entretanto, não é qualquer desejo que teria o poder de produzir um sonho. Um desejo diurno insatisfeito, por exemplo, precisaria de um reforço proveniente do inconsciente para produzir um sonho. $\mathrm{Ou}$ seja, o desejo Pcs/Cs só se tornaria excitador de um sonho na medida em que consiga despertar outro desejo paralelo, advindo do inconsciente.

De acordo com Rudge (1999) o processo de formação do sonho tem como 'força responsável por sua produção' um desejo inconsciente que se articula aos pensamentos oníricos. Segundo a autora, esta seria a ideia por trás da conhecida metáfora freudiana que apresenta o desejo inconsciente como "capitalista do sonho", uma vez que este seria responsável por prover os recursos, ou seja, a energia psíquica indispensável à formação do sonho. Na pena de Freud (1900) temos o que segue:

Ele (pensamento diurno) precisa de um capitalista que possa arcar com o gasto, e o capitalista que fornece o desembolso psíquico para o sonho é, invarável e indiscutivelmente, sejam quais forem os pensamentos do dia anterior, um desejo oriundo do inconsciente. (Freud, 1900, p. 590)

Sonhos, que realizam desejos da forma mais direta, como o das crianças (Freud, 1900/1996), servem como exemplo do modo principal de funcionamento do nosso psiquismo, neles a censura é quase inteiramente inexistente. 
A censura psíquica, guardiã da nossa saúde mental, impede que os impulsos do (desejo) inconsciente se manifestem durante o dia. Como efeito deste impedimento, surgem os sintomas, que devem ser considerados como a realização distorcida de desejos inconscientes. À noite, os sonhos também expressam a realização destes desejos recalcados, porém, com a autorização e controle de uma censura psíquica menos rigorosa, que durante o sono se torna mais flexível.

Ao mesmo tempo em que descobre sua fórmula de que o sonho representa a realização disfarçada de um desejo ('Wunscherfüllung'), Freud se vê confrontado com algo que merece sua atenção para defendê-la: os sonhos de angústia. Diz o inventor da psicanálise (1900/1996):

Sem dúvida nos terá surpreendido a todos saber que os sonhos não passam de realizações de desejos, e não apenas em virtude da contradição trazida pelos sonhos de angústia. (Freud, 1900/1996, p. 580)

Em sua virada teórica de 1920, quando postula um "além do princípio do prazer", Freud apresenta o problema dos 'sonhos traumáticos' como um dos principais motivos que o levaram a tal empreendimento. Segundo Rudge (1999), o fato destes sonhos reconduzirem repetidamente o sonhador à situação traumática, constitui o obstáculo mais embaraçoso à proposta inicial de considerar o psiquismo como inteiramente submetido ao princípio do prazer e os sonhos como realização de um desejo. Sem abrir mão da sua ideia original de que o sonho é a realização de um desejo, Freud passa a considerar os sonhos traumáticos, primeiramente, como falhas no processo de elaboração onírica, cuja missão primordial seria a de permitir o sono e satisfazer o desejo de dormir. Os sonhos de angústia seriam, portanto, consequência da realização indisfarçada de um desejo recalcado. Quinze anos após a publicação de sua "Interpretação dos Sonhos" (1900), sem se esquivar da polêmica, mas ainda agarrado ao seu "princípio de prazer", Freud (1915-16/1996) enfrenta a questão da seguinte maneira:

O leigo pergunta: 'Onde está a realização de desejo?' Instantaneamente, tendo ouvido falar que se supõe serem os sonhos realizações de desejos, no próprio ato de emitir a pergunta, ele a responde com uma rejeição. Imediatamente pensa em inumeráveis experiências suas com sonhos, nas quais o sonho foi acompanhado por sentimentos que vão desde o desagradável até uma acentuada ansiedade, de modo que a afirmação feita pela teoria psicanalítica dos sonhos parece-lhe muitíssimo 
improvável. (...) os desejos, nesses sonhos deformados, são desejos proibidos rejeitados pela censura - e a existência desses desejos justamente foi a causa da deformação onírica. (Freud, 1915-16/1996, p. 216)

Logo em seguida, no mesmo texto, Freud apresenta outro importante argumento em sua defesa da teoria dos sonhos enquanto realização de desejos, ainda em consonância com o seu princípio de prazer. Acompanhemos Freud (1915-16/1996):

Não há dúvida de que uma realização de desejo deve proporcionar prazer; mas então surge a pergunta: 'A quem?' Â pessoa que tem o desejo, naturalmente. Mas, como sabemos, a relação do sonhador para com seus desejos é uma relação muito especial. Ele os repudia e os censura - não tem nenhuma simpatia por eles, em suma. De modo que sua realização não lhe dará prazer, e sim o oposto. (Freud, 1915-16/1996, p. 217)

Vale destacar aqui a importante ideia freudiana expressa na passagem acima - de um desejo cuja realização não traria prazer ao sujeito, e sim o oposto -, a qual nos remete ao conceito lacaniano de gozo, enquanto realização de um desejo. Conforme veremos mais detalhadamente no decorrer do trabalho, uma das principais definições lacanianas de gozo é aquela que o descreve como um prazer dolorido. "O gozo, segundo Lacan, não é exatamente prazer, mas sim feito de prazer e dor." (Vieira, 2002, p. 119). Desta forma, a concepção de um para além do princípio de prazer começa a se delinear na teoria freudiana.

Para chegar às reformulações propostas em seu "Além do princípio de prazer" (1920), Freud contou com casos de repetição observados em sua clínica, que ele não poderia incluir sob seu guarda-chuva teórico do "princípio de prazer". Dentre tais fenômenos repetitivos, um dos mais gritantes e intrigantes para Freud foi, como vimos, o dos sonhos traumáticos. Assim, nesta transição teórica, a compulsão à repetição passa a ser encarada como "independente do princípio do prazer e podendo sobrepujá-lo" (Rudge, 1999, p. 66). Freud, ao observar que os sonhos traumáticos tendem a levar o sujeito de volta para a situação que gerou a neurose traumática, passa a reconhecer que esses casos seriam conflitantes com a teoria do sonho como realização (mesmo que deformada) de desejo. A teoria psicanalítica passa a considerar esses sonhos como exceção, uma vez que "no caso 
da neurose traumática, a função do sonho fora perturbada e desviada em relação a seu objetivo habitual" (Rudge, 1999, p. 66). Freud chega à conclusão de que a função dos sonhos traumáticos seria, portanto, a de buscar obter, através da repetição, uma ligação psíquica da impressão traumática, ou seja, uma elaboração da experiência traumática de forma que o princípio do prazer possa ser restabelecido.

Assim, a proposta do sonho como realização de desejo não é descartada por Freud, mas passa a dividir espaço com a tentativa de obtenção de controle e a ligação do processo primário, colocado fora de ação pelo trauma. Sobre a importância desta nova concepção teórica para a clínica psicanalítica, Rudge (1999) vai dizer o seguinte:

O alcance desta reformulação no manejo dos sonhos na clínica é grande. A própria fonte ou causa do sonho, passa a estar, em muitos casos, referida a um acontecimento traumático. (Rudge, 1999, p. 67)

\subsection{Experiência de satisfação}

Quando a pessoa que ajuda executa o trabalho (...) para o (bebê) desamparado, este último fica em posição (...) de remover o estímulo endógeno. A totalidade do evento constitui então a experiência de satisfação, que tem as consequências mais radicais no desenvolvimento das funções do indivíduo. (Freud, 1950[1895]/1996, p. 370)

Conforme podemos apreender desta didática passagem de Freud, o desejo estaria ligado, portanto, às primeiras percepções, às representações e aos significantes que compõem as imagens dessas percepções, e cujo reencontro é indispensável para sua realização. A análise dos sonhos, dentre outras coisas, também serviu para Freud construir um modelo do aparelho psíquico que definia o desejo como investimento de uma imagem mnêmica ligada à experiência de satisfação de uma necessidade. Nessa linha de pensamento, o desejo se define como sendo a reprodução alucinatória da primeira experiência de satisfação, ou seja, a reprodução de um registro de satisfação, o qual, por referir-se a um tempo passado, já se encontra ausente. Com efeito, esta 'satisfação perdida' ou que 
cessou de se realizar, passa a constituir o 'não-realizado' da estrutura do desejo. Com a reprodução alucinatória, algo disso torna-se presentificado, porém sempre 'parcialmente', sempre marcado por uma 'falta' que, para Lacan, seria estrutural.

A ideia de uma vivência de satisfação aparece logo no início da obra de Freud, em seu 'Projeto para uma psicologia científica' (1950[1895]), sendo apresentada como a eliminação da $Q$ resultante dos estímulos internos. Tal conceito está intimamente relacionado ao estado de desamparo original do ser humano. Senão vejamos: no início era um bebê faminto gritando ou dando pontapés, como reflexo de um desconforto causado por uma excitação interna, contínua e sem trégua. Ocorre que esses espasmos motores por si só são inúteis para a eliminação do desconforto na fonte corporal. Com o auxílio externo, o bebê obtém o que Freud chamou de uma "vivência de satisfação" através do apaziguamento dos estímulos internos, ficando assim associada ao traço mnêmico da excitação produzida pela necessidade. Estabelece-se assim o que Freud chamou de uma facilitação ('Bahnung'), de forma que ao se repetir o estado de necessidade, surge um impulso psíquico visando reinvestir a imagem mnêmica do objeto, "com a finalidade de reproduzir a satisfação original" (Garcia-Roza, 2002, p. 183). Este conjunto de neurônios interligados, que representam os elementos de uma vivência de satisfação, torna-se um caminho preferencial de eliminação e é definido por Freud como desejo. Vejamos o que diz Freud (1900):

Em decorrência do vínculo assim estabelecido, na próxima vez em que essa necessidade for despertada, surgirá de imediato uma moção psíquica que procurará recatexizar a imagem mnênica da percepção e reevocar a própria percepção, isto é, restabelecer a situação da satisfação original. Uma moção dessa espécie é o que chamamos de desejo. (Freud, 1900, p. 594)

Assim, para Freud o desejo é satisfeito apenas uma vez, e qualquer manifestação posterior do desejo é apenas um impulso ('Drang') que visa restabelecer, às vezes ao ponto de uma alucinação, a imagem de um objeto irremediavelmente perdido. A pressão do estímulo interno somada à prematuridade do bebê humano, que o torna extremamente dependente dos cuidados do adulto, o conduz não a pensar ou desejar a coisa que restabeleceria seu repouso, mas sim a aluciná-la. Estamos diante, portanto, não apenas de um ser prematuro, pouco preparado para a vida, mas, sobretudo, lidamos com um 
psiquismo dotado de um princípio que podemos dizer contrário às exigências da vida como tal. Um psiquismo capaz de alucinar uma satisfação terá de se defrontar com o consequente desapontamento, uma vez que "na ausência do objeto real não pode haver satisfação" (Garcia-Roza, 2002, p. 183).

Freud não identifica, em nenhum momento, necessidade (biológica) com desejo. A necessidade pode ser satisfeita através de determinados objetos adequados, como, por exemplo, comida. Já o desejo é regido por traços de memória referentes a uma "excitação" anterior, e à eterna busca por voltar a investir tais imagens. Ou seja, podemos dizer que o objeto do desejo nunca mais será aquele original, mas sempre um substituto daquele. A psicanálise nos mostrou que a partir do momento em que o objeto original do desejo inconsciente, sexual e incestuoso - foi perdido, como efeito do recalque, este passa a ser frequentemente representado por uma série interminável de objetos substitutos, nenhum dos quais, no entanto, capaz de trazer satisfação plena.

\subsection{A concepção lacaniana do desejo}

O mundo freudiano não é um mundo das coisas, não é um mundo do ser, é um mundo do desejo como tal.

(Lacan, 1954-55/2010, p. 301)

Se há um conceito que pode reivindicar o posto central de relevância no pensamento de Lacan, este é o conceito de desejo. Em seu Seminário 2 - O eu na teoria de Freud e na técnica da psicanálise - Lacan chega a afirmar que "O desejo, função central em toda experiência humana, é desejo de nada que possa

ser nomeado. É, ao mesmo tempo, este desejo que se acha na origem de qualquer espécie de animação" (1954-55/2010, p. 302). Quando Lacan fala de desejo, não é de qualquer desejo a que ele se refere, mas trata-se sempre de desejo inconsciente; e o desejo inconsciente é sempre sexual. Sobre a natureza inconsciente do desejo, Miller (1997, p. 204) deixa claro que "o desejo é a vontade mais além do que podemos conhecer conscientemente". Pode-se dizer, resumidamente, que o objetivo do tratamento psicanalítico seria, portanto, o de (re)conduzir o analisando 
a reconhecer a verdade sobre seu desejo. Desta maneira, para a psicanálise, o que é importante é "ensinar o sujeito a nomear, a articular, a fazer passar para a existência, este desejo que está, literalmente, para aquém da existência, e por isto insiste." (Lacan, 1954-55/2010, p. 309).

Para Lacan, assim como para Freud, o desejo é desejo do sujeito por um objeto fundamentalmente perdido. Os dois mestres da psicanálise propõem que o desejo nasce, portanto, de uma experiência de perda - perda de gozo e de amor, para sermos mais específicos. Ou seja, falta de amor e falta de gozo. Assim, para Freud, qualquer busca por um objeto é, na verdade, uma tentativa de reencontrá-lo e consiste em um esforço para se reviver a satisfação que já foi vivida. Lacan, por sua vez, vai defender a ideia de que o objeto do desejo está localizado antes do desejo, funcionando exatamente como sua causa. Em qualquer caso, o desejo permanece marcado - servindo como um lembrete - de um gozo e um amor perdidos.

\subsection{Desejo, necessidade e demanda}

$O$ desejo se esboça na margem em que a demanda se rasga da necessidade. (J. Lacan, Escritos, p. 828)

Uma das principais críticas de Lacan às teorias psicanalíticas de sua época, diz respeito à tendência destas em confundir o conceito de desejo com os conceitos de demanda e necessidade. Com o objetivo de corrigir esta distorção, por volta de 1958, Lacan insistiu na importante distinção entre estes três conceitos.

Necessidade foi definida, tanto por Lacan quanto por Freud, como sendo de ordem fisiológica, um estímulo que surge de acordo com as carências do organismo, e que é passível de ser completamente satisfeita, mesmo que temporariamente. A necessidade se opõe à ideia de pulsão ('Trieb'), visto que esta é ligada ao erotismo e não se satisfaz como aquela, ou seja, é uma força constante. O sujeito humano, tendo nascido em estado de total desamparo, é incapaz de satisfazer suas próprias necessidades nos primeiros anos de vida, dependendo 
exclusivamente do Outro para ajudá-lo a satisfazê-las. De forma a obter a ajuda desse Outro, o infante expressa suas necessidades vocalmente, ou seja, a necessidade é articulada na linguagem em forma de demanda. Uma vez que o desejo só se veicula a partir de uma demanda, ele é, portanto, submetido à lei da linguagem, que pode também ser caracterizada pelo nome-do-pai, ou simplesmente, falo. Depreende-se daí a seguinte fórmula lacaniana: demanda + lei = desejo, a qual nos permite vislumbrar o que Lacan indicou como "el estrecho nudo del deseo y de la Ley" 3 (1959-60/2009, p. 215).

Os primeiros apelos do bebê (choros, espasmos e gritos), apesar de primitivos, servem de maneira eficaz para fazer com que o Outro (mãe) venha a seu auxílio, ajudando-o a satisfazer suas necessidades. Um exemplo clássico de necessidade biológica é a fome, a qual o infante articula em seus gritos (demanda), de forma a fazer com que a mãe venha alimentá-lo. É a natureza simbólica dos gritos infantis que constitui o centro do conceito lacaniano de demanda. Respondendo à própria pergunta sobre o que é a demanda, Lacan é claro e conciso ao afirmar que "é aquilo que, a partir de uma necessidade, passa por meio do significante dirigido ao Outro" (1957-58/1999, p. 91).

Tendo em vista que o objeto que satisfaz a necessidade da criança é fornecido pelo Outro, o ato de amamentar, por exemplo, passa a ser percebido pela criança como algo além da alimentação pura e simples, adquirindo o status de 'prova do amor do Outro'. O objeto (leite) torna-se 'inessencial', diz Roudinesco (1998, p. 147), uma vez que 'a demanda é demanda de amor'. Introduz-se assim algo que vem causar uma divisão para o sujeito entre necessidade e demanda; a presença do Outro logo adquire uma importância em si mesma; uma importância que vai além da satisfação da necessidade, passando a simbolizar exatamente o 'amor do Outro'; e quando esse Outro de alguma maneira falta - e invariavelmente falta - então há desamparo. Acompanhemos Miller:

El Otro de la demanda detenta los objetos de satisfacción, el objeto adquiere valor de don simbólico, de testimonio de amor; y si el Otro no da, entonces hay desamparo. $^{4}$ (Miller, 2007, p. 94)

\footnotetext{
${ }^{3} \mathrm{O}$ forte vínculo entre o desejo e a lei.

${ }^{4}$ O Outro da demanda detém os objetos de satisfação, o objeto adquire valor de presente simbólico, de testemunho do amor; e se o Outro não dá, então há desamparo.
} 
A demanda começa a ter então uma dupla função, servindo ao mesmo tempo para articular a necessidade e também como demanda de amor; é exatamente esta dupla função da demanda que será responsável pelo nascimento do desejo. A partir de então, a satisfação da necessidade passa a ser completamente eclipsada pela função simbólica da demanda, qual seja, funçãosímbolo do amor materno. O objeto sobre o qual a demanda incide passa a ser valorizado mais pelo seu valor simbólico do que pela sua capacidade de satisfazer a necessidade. Servindo-se de um exemplo aparentemente banal, porém preciso, Lacan toca no cerne da questão da demanda, ao demonstrar que, ao entrar na dimensão da linguagem, o sistema de necessidades é remodelado e alçado ao infinito:

Não é à toa que as crianças pedem a lua. Elas pedem a lua porque é da natureza de uma necessidade que se exprime por intermédio do sistema significante pedir a lua. Por isso, aliás, não hesitamos em prometê-la. (Lacan, 1957-58/1999, p. 92)

Apesar do Outro ser capaz de prover os objetos que o sujeito requisita para satisfazer suas necessidades, este mesmo Outro é incapaz de prover o amor incondicional pelo qual o sujeito anseia. Como consequência disto, mesmo após as necessidades articuladas na demanda terem sido satisfeitas, este outro aspecto da demanda, a saber, o anseio por amor - insaciável e incondicional - resta insatisfeito; e este resto é, precisamente, desejo. É como se o Outro da demanda, usando uma expressão popular, "deixasse sempre a desejar"; ou seja, não extinguisse nunca o desejo. Do encontro do sujeito com o Outro, sempre há um resto; um excesso ou uma falta, representados ao mesmo tempo em um único objeto - o objeto $a$ - objeto especial construído por Lacan, capaz de causar, de pôr em movimento o desejo do sujeito.

Articulando desejo, necessidade e demanda, Lacan (1966/2008, p. 268) vai propor que "o desejo não é nem o apetite da satisfação, nem a demanda de amor, mas a diferença que resulta da subtração do primeiro à segunda". O desejo seria, portanto, o excedente produzido pela veiculação da necessidade na demanda. Ao contrário da necessidade, que pode ser satisfeita, e que cessa temporariamente, o desejo não cessa nunca, sendo impossível sua satisfação. É exatamente esta 
impossibilidade de satisfação, característica do desejo, que nos poria em movimento.

A distinção feita por Lacan entre desejo e necessidade retira completamente o desejo do campo da biologia. O desejo é exclusivamente humano na medida em que é dirigido a outro desejo ('desejo do Outro) ou mesmo a um objeto que é totalmente inútil do ponto de vista biológico; e sobre este segundo aspecto, a experiência analítica certamente demonstra as características paradoxais, desviantes, erráticas e excêntricas que distanciam o desejo de qualquer coisa que poderia ser classificada como 'necessária'. Garcia-Roza (2000) nos ensina:

O Desejo somente será humano quando se dirigir para um objeto não-natural (...). Dois desejos animais tornam-se desejos humanos quando abandonam os objetos naturais para os quais estavam voltados e se dirigem um para o outro. Desejar o Desejo do outro, eis o que caracteriza o Eu como Eu humano. (Garcia-Roza, 2000, p. 142)

\subsection{Desejo como desejo do Outro}

Human history is the history of desired Desires. ${ }^{5}$

(Kojève, 1947/1980, p. 6)

Seu desejo é uma ordem. (Gênio da lâmpada)

Uma das fórmulas lacanianas mais repetidas sobre o desejo é: “o desejo, em sua raiz e sua essência, é o desejo do Outro” (1961/1992, p. 180). Este mesmo aforismo, repetido por Lacan três anos depois, nos seguintes termos: “O desejo do homem é o desejo do Outro" (1964/2008, p. 229), pode ser compreendido a partir de diversas leituras complementares, sobre algumas das quais discorreremos a seguir. Comecemos pela ideia de que o desejo é essencialmente 'desejo do desejo do Outro'; o que poderia significar tanto 'desejo de ser o objeto do desejo do Outro' quanto 'desejo de ser reconhecido pelo Outro'. Segundo Kojève (1947/1980, p. 6), o desejo é essencialmente humano quando o que se deseja não é o corpo, mas sim o desejo do Outro; quando o que se deseja é ser desejado,

\footnotetext{
${ }^{5}$ A história humana é a história de Desejos desejados.
} 
amado e reconhecido pelo Outro. Ocorre que a criança só vem a reconhecer-se como sujeito nos olhos do Outro, como um reflexo no olhar do Outro. Assim, um desejo nunca é autenticamente um desejo próprio: o desejo (de reconhecimento) passa necessariamente pelo Outro. E na medida em que o Outro continua 'outro', a natureza do desejo permanece fundamentalmente enigmática. O sujeito deseja o desejo do Outro, sem nunca saber muito bem o que isso envolve. Esse desejo de ser o objeto do desejo do Outro é claramente representado no primeiro tempo do complexo de Édipo, quando o sujeito deseja ser o falo da mãe, ou seja, ser aquilo que lhe falta, e que, portanto, ela deseja.

Esta mesma vicissitude do desejo pode também ser observada nas instituições e grupos, nas quais os sujeitos sucumbem ao discurso do líder, não de forma passiva, muito menos voluntária, mas porque, de acordo com Baremblitt (1996, p. 51), este discurso institucional seduz e satisfaz certos desejos inconscientes. Como se a frase que emana a partir do inconsciente, de generais a soldados, fosse a seguinte: "Meu desejo é ser desejado, amado e reconhecido pelo Outro (instituição)". Freud faz uma extensa exposição a respeito deste fenômeno em sua "Psicologia das Massas" (1921/1996), no qual o líder é colocado como ideal do eu e obedecer a ele basta para o sujeito se sentir bom e amável; isso ainda vai lhe economizar conflitos com o ideal do eu, agora externalizado. Nos termos de Freud (1921/1996) encontramos o seguinte:

Um grupo é um rebanho obediente, que nunca poderia viver sem um senhor. Possui tal anseio de obediência, que se submete instintivamente a qualquer um que se indique a si próprio como chefe. (Freud, 1921/1996, p. 91)

Trata-se, com efeito, de uma espécie de proteção inconsciente contra a realização do próprio desejo. Nesta solução de compromisso, o Outro deseja por mim, assim é mais seguro; desta forma, o sujeito protege-se de seus ameaçadores desejos inconscientes, de raízes incestuosas e parricidas. "Ante o desejo é mais seguro recuar", conclui Braunstein (2007, p. 323).

Outra possível leitura desta fórmula lacaniana é que o objeto do desejo é essencialmente um objeto desejado por alguém mais. Esta seria a primeira proposição lacaniana, aquela da rivalidade especular, e que Lacan ilustra com o 
capitalismo e o desejo de ter o que o outro tem, mesmo que não sirva para nada. É o desejo da criança pelo objeto que está na mão da outra criança. O que tornaria um objeto desejável não seria, portanto, nenhuma qualidade intrínseca ao objeto, mas simplesmente o fato deste objeto ser desejado por mais alguém. Como efeito desta leitura, temos a diminuição de qualquer significação especial que possa ser atribuída a qualquer objeto, ao mesmo tempo em que nos permite vislumbrar a existência de um sem-número de objetos. Ao desejar aquilo que um outro deseja, posso fazer com que este mesmo outro reconheça meu direito de possuir tal e qual objeto; ou simplesmente que este outro me reconheça. Percebe-se então que o desejo é um produto social, uma vez que é constituído sempre a partir de uma relação dialética com os 'desejos de outros sujeitos'. A respeito desta relação dialética, Roudinesco (1998, p. 147) vai dizer que o sujeito busca ser reconhecido de forma absoluta pelo Outro, mesmo que seja ao preço de uma luta de morte. A autora aborda o desejo de reconhecimento fazendo alusão ao combate mortífero (imaginário) no qual o sujeito se engaja, por puro prestígio, até que seu desejo prevaleça e seja reconhecido pelo Outro. Um dos dois desejos terá de ser destruído, nesta luta onde cada um dos envolvidos arrisca a própria vida pelo reconhecimento. O desejo é, portanto, essencialmente, um desejo de ser... reconhecido. Sobre isso, Miller (2012, p. 4) diz o seguinte: "Lacan se ligou assim ao tema do reconhecimento, a ponto de fazer do desejo de reconhecimento o desejo mais profundo do sujeito". Reconhecimento este que, segundo o autor, seria da ordem da comunicação. Da mesma forma, Garcia-Roza (2002) entende a questão do reconhecimento através da linguagem: "Esse reconhecimento só pode ser feito pela palavra.” (2002, p. 190).

Porém, apesar de se tratar de uma 'luta de morte' pelo reconhecimento, é preciso que os dois adversários permaneçam vivos, pois, caso um deles morra, o reconhecimento se torna impossível (Garcia-Roza, 2000, p. 143). Assim sendo, a condição de possibilidade para o reconhecimento é que o perdedor, não querendo morrer, submeta-se e reconheça o vencedor como seu 'senhor' e a si mesmo como 'escravo'. Está aí esboçada a chamada 'dialética do senhor e do escravo', parábola hegeliana que faz uso da dinâmica dominação-servidão para ilustrar o que seria o processo de surgimento do homem a partir da animalidade. 
A propósito, nesta dialética do senhor e do escravo, de que lado estaria o gozo? Do lado do escravo é claro! Entretanto, o escravo precisa do senhor (da lei) para gozar (transgredir), não podemos nos esquecer disso. Certa vez, em um seminário de psicanálise, ouvi um bom exemplo do que seria esse "gozo do lado do escravo". Trata-se do testemunho de alguém que trabalhou no mesmo hospital onde o fato se dava. Vamos à história:

Um jovem paciente interno de um hospital psiquiátrico fugia a cada 2-3 meses da instituição, somente para andar alguns quilômetros de trem. Ia para o norte, depois para o sul e, poucos dias após a fuga, procurava a delegacia de polícia mais próxima para se apresentar e ser reconduzido ao hospital de onde fugira.

De que lado, portanto, está o gozo nesse exemplo? Dos médicos-psiquiatras que cuidavam do jovem? Dos vigias que não conseguiam impedir suas 'escapadas'? Dos policiais que frequentemente o reconduziam ao hospital? O gozo está sempre do lado do escravo! Neste caso, do jovem paciente gozador.

Voltando ao desejo, Garcia-Roza vai citar Hegel para esclarecer a aparente contradição entre a proposição de que o desejo humano é sempre desejo de outro desejo e o fato de que, enquanto humanos, também desejamos objetos:

Hegel responde que o desejo humano volta-se para objetos na medida em que estes se constituem como objetos do desejo de outros homens. Nesta medida, ao nos apossarmos desses objetos, estamos afirmando nosso domínio sobre o desejo do outro. O que o desejo humano deseja é possuir o desejo do outro, é ser desejado ou amado pelo outro, é ser reconhecido em seu valor humano (Garcia-Roza, 2002, p. 190)

Esta característica do desejo, de desejar aquilo que o Outro deseja, torna-se especialmente evidente na histeria. A histérica é aquela que sustenta o desejo de um outro, e que converte este desejo alheio em seu próprio. Diz Lacan, em seu Seminário 5 (1957-58/1999, p. 407), que "a histérica (...) situa esse para-além sob a forma de um desejo como desejo do Outro". Temos um bom exemplo disso no caso Dora, famosa analisanda de Freud, que deseja outra mulher, Frau K, porque ela, Dora, se identifica com Herr K (esposo de Frau K), apropriando-se então do seu desejo. Assim, o que é importante na análise de um sujeito histérico não é 
ajudá-lo a encontrar o objeto do seu desejo, mas sim descobrir o lugar a partir do qual ele deseja, ou seja, o sujeito com quem se identifica.

Tirando proveito da ambiguidade da preposição francesa de, pode-se também ler a frase de Lacan como 'o desejo é desejo pelo Outro'. Esta leitura também se autoriza na medida em que Lacan (1959-60/2009, p. 84) reconhece a importância de ter havido um homem (Freud) que, em um determinado momento da história, se levantou para dizer que o desejo pela mãe - o desejo incestuoso - é o desejo essencial. O desejo enquanto 'desejo de outra coisa' (Lacan, 195657/1995, p. 309) é outro sentido que pode ser atribuído ao aforismo lacaniano, uma vez que é impossível desejar o que já se tem. O objeto do desejo é continuamente deslocado, daí porque o desejo é caracterizado por Lacan como uma metonímia, sendo diferente daquilo que pode ser veiculado pela demanda. "O paradoxo do desejo reside nisto" (Dor, 1989, p. 148). Outra possível abordagem evoca o desejo como sendo originário do campo do Outro (inconsciente). Não custa lembrar que o desejo de que nos fala Freud é sempre desejo inconsciente.

A primeira pessoa a ocupar o lugar do Outro é a mãe, e, num primeiro momento, o infante encontra-se à mercê de seus caprichos e desejos. É somente quando o pai articula o desejo com a lei, ao castrar a mãe, que o sujeito vê-se livre de submeter-se aos caprichos do desejo materno. Lacan faz uso do adjetivo 'complicada', ao qualificar a relação da criança com a mãe, uma vez que a mãe "impõe, mais do que sua lei, aquilo a que chamei sua onipotência ou seu capricho" (1957-58/1999, p. 473). Em decorrência disso, o que o sujeito experimenta, quando confrontado com o desejo do Outro, é angústia, pois não tem a mínima ideia de que objeto ele representa para esse desejo. Che vuoi? Que queres de mim? 


\subsection{Metonímia do desejo}

Will remain in but a fleeting illusion to be pursued, but never attained $^{6}$

(B. Marley; "War")

A metonímia costuma ser definida como uma figura de linguagem na qual um termo é utilizado no lugar de outro, devido à possibilidade de relação entre eles. A palavra metonímia tem origem grega, sendo formada pelo prefixo "meta" (= mudança) + "onímia" (= nome). Vejamos a definição que o Dicionário Aulete nos fornece: sf. 1. Ling. Figura de linguagem baseada no uso de um nome no lugar de outro, pelo emprego da parte pelo todo, do efeito pela causa, do autor pela obra, do continente pelo conteúdo etc. (p.ex.: beber um copo no lugar de beber a cerveja do copo). [F.: Do gr. metonimía,as.]. Na metonímia, uma palavra é utilizada para denotar um objeto ao qual ela não se refere literalmente, mas com o qual está estreitamente relacionada. Pode-se dizer, portanto, que na metonímia trata-se de uma relação entre objetos, tendo como base a proximidade entre os elementos combinados, por efeito de contiguidade.

Seguindo Jakobson em sua análise estrutural da linguagem, Lacan associa a metonímia ao eixo combinatório da linguagem, em oposição ao eixo de seleção (metafórico). A metonímia, portanto, diz respeito às possibilidades de combinação dos significantes em uma mesma cadeia significante (relações 'horizontais'), enquanto que na metáfora trata-se das substituições possíveis de um significante em uma cadeia, por outro significante de uma outra cadeia significante (relações 'verticais'). Lacan vai estabelecer, assim, um entrelaçamento inovador entre metáfora/substituição e metonímia/deslocamento, associando as duas figuras de linguagem com os dois mecanismos principais do trabalho do sonho para driblar a censura. Não é a toa que uma das ideias lacanianas mais conhecidas é de que o inconsciente seria estruturado como uma linguagem. Sobre este 'drible na censura' Lacan vai dizer o seguinte:

\footnotetext{
${ }^{6}$ Permanecerá em apenas uma ilusão passageira a ser perseguida, mas nunca alcançada.
} 
A Verschiebung ou deslocamento, é (...) essa virada da significação que a metonímia demonstra e que, desde seu aparecimento em Freud, é apresentada como o meio mais eficaz de que dispõe o inconsciente a fim de burlar a censura. (Lacan, 1966/2008, p. 242)

Lacan aborda a metonímia a partir do movimento diacrônico de um significante a outro ao longo da cadeia significante, na medida em que um significante constantemente se refere a outro, em um deslizamento contínuo do significado. Como observa Valas (2001, p. 16), “o desejo se aloja na metonímia da cadeia significante, de modo que ele é impossível de dizer". No intervalo entre S1 e S2, nesse lugar de hiância, vazio de significado, encontram-se tanto sujeito quanto desejo. $\mathrm{O}$ desejo, visto como aquilo que põe o sujeito em movimento, causando-o, nos remete ao movimento diacrônico que caracteriza a metonímia - a metonímia também é movimento, é deslocamento. Em uma de suas inúmeras tentativas de definir o desejo, Lacan diz o seguinte: "El deseo lo hemos definido en otro lado como la metonimia de nuestro ser". 7 (Lacan, 1959-60/2009, p. 382)

O conceito de desejo também pode ser relacionado a este mesmo processo de deslizamento sem-fim, uma vez que desejo para a psicanálise é sempre desejo de algo mais (Lacan, 1956-57/1995, p. 309). Para Lacan, é na medida em que a libido cria os diferentes estádios do objeto, que os objetos nunca são bem isso. (1954-55/2010, p. 302). No instante em que o objeto de desejo é alcançado, neste instante exato, o desejo do sujeito inclina-se imediatamente em direção a outro objeto. Ensina Lacan (1966/2008):

E os enigmas que propõe o desejo (...), não são devidos a nenhum outro desregramento do instinto senão a terem sido encarrilhados, nos trilhoseternamente tendidos para o desejo de outra coisa -, na metonímia. (Lacan, $1966 / 2008$, p. 249)

Chegamos ao ponto de poder inferir que os objetos metonímicos do desejo, portanto, sempre podem ser trocados e, ainda, que todo objeto amoroso é sempre uma substituição. Enquanto desejamos, nada sabemos sobre aquilo que desejamos, pois, na letra de Freud, o desejo é fundamentalmente inconsciente; no

\footnotetext{
${ }^{7} \mathrm{O}$ desejo, definimo-lo em outra parte como a metonímia do nosso ser.
} 
meio deste deslizamento metonímico de objetos, de vez em quando, um ou outro salta aos olhos, sem termos a mínima ideia do por quê (Lacan, 1962-63/2005).

É como se, de objeto em objeto, o desejo deslizasse numa série interminável, numa satisfação sempre adiada e nunca atingida. Trata-se da formulação deste que talvez seja o mais profundo de todos os desejos humanos, pelo menos o mais constante, qual seja, nos termos de Lacan (1956-57/1995, p. 309), o 'desejo de outra coisa'.

Condenado à insatisfação perpétua por definição, estamos diante de um importante paradoxo do conceito psicanalítico de desejo: a satisfação do desejo consiste essencialmente na preservação da sua insatisfação própria, uma vez que um sujeito continua a ser sujeito apenas na medida em que - para usar o pleno significado da denominação 'manque-à-être' (falta-de-ser) - ele é uma falta-de-ser que deseja ser (reconhecido).

\subsection{Falta e desejo}

Enquanto na perspectiva filosófica clássica a relação do homem com o mundo é uma relação de ser a ser, na perspectiva freudiana essa relação é de ser a falta. Este é o caminho indicado por Lacan para abordarmos a questão do desejo em Freud. (Garcia-Roza, 2002, p. 186)

O desejo tratado, com Lacan, na sua versão de falta, introduz um sujeito que, para constituir-se como tal, deverá confrontar-se com o seu desejo, ou seja, com a falta de satisfação absoluta. "Essa falta é constitutiva do sujeito, uma falta de estrutura" (Rudge, 2005, p. 86). O conceito de falta ('manque') aparece sempre intimamente relacionado ao conceito de desejo na teoria lacaniana. Em seu seminário 8 - A transferência (1960-61) - Lacan afirma que a falta é aquilo que faz o desejo surgir. O desejo está longe de ser prometido à completude, pela simples e precípua razão dele ser sempre decorrente de uma perda (castração), responsável pela causação do sujeito. Segundo Garcia-Roza (2008, p. 142) o desejo só pode ser pensado na sua relação com o "desejo do Outro" e aquilo para 
o qual ele aponta não é algo empírico, mas sim uma falta, a falta constituinte do sujeito. Lacan concebe a falta como estruturante, como aquilo que permite a constituição do sujeito enquanto ser desejante, o que permite o movimento, o deslizamento metonímico dos significantes e dos objetos. Sobre esse "vazio estruturante", Vieira (2008) diz o seguinte:

A falta é o que permite que haja pacto e limites, razão pela qual Lacan a define como um "vazio estruturante". O apagamento da função-falta está longe de ser uma pacificação. Estar fora da falta é estar no angustiante regime do tudo ou nada, da equivalência entre todas as demandas. (Vieira, 2008, p. 32)

Quando o termo aparece no ensino de Lacan, em 1955, começa por designar o que Lacan chamou de falta de ser. Não se trata, portanto, da falta deste ou daquele objeto, mas falta de ser... reconhecido enquanto sujeito. Mais adiante, Lacan virá a estabelecer ainda uma distinção entre 'falta-de-ser' (manque à être), relacionada com o desejo, e 'falta-de-ter' (manque à avoir), que ele relacionou com a demanda. Acompanhemos Lacan:

O desejo é uma relação de ser com falta. Esta falta é falta de ser, propriamente falando. (...) Se o ser fosse apenas o que é, não haveria nem sequer lugar para se falar dele. O ser se põe a existir em função mesmo desta falta. É em função desta falta, na experiência de desejo, que o ser chega a um sentimento de si em relação ao ser. (Lacan, 1954-55/2010, p. 302)

Percebemos assim, o alto valor atribuído a este conceito pelo mestre francês. Freud, com o papel crucial conferido ao 'complexo de castração', e na elaboração teórica sobre o jogo do Fort-da, já ressaltava a importância simbólica da percepção pelas crianças da presença e, principalmente, da ausência tanto do pênis (castração) como da mãe-carretel (Fort-da). Algo sempre falta. Para ilustrar a importância da falta e da incompletude, como pré-condição do desejo, recordemos do antigo jogo de tabuleiro de nome 'Resta 1'. A pré-condição para que este jogo se inicie é que falte uma peça. É exatamente porque falta uma peça que é possível jogar. Se não faltasse tal peça, seria impossível movimentar as demais peças no tabuleiro. Resultado: estagnação.

A falta seria, portanto, pré-condição para o início do jogo, aquilo que abre espaço para o movimento das peças (no jogo em questão) e do sujeito (na vida). 
Voltando para a psicanálise, pode-se dizer que é preciso que a mãe falte, em algum momento, para que a criança possa desejar - possa respirar. A falta, representada nesse caso pelo ar, pelo espaço vazio, tem a função de proteger, de amortecer o impacto. Pensemos, por exemplo, no plástico bolha, ou então, na espuma, no isopor. Como ensina Lacan, aquilo que causa angústia não é a falta, mas sim a falta de falta (1962-63/2005).

Uma vez que não posso tudo, que algo falta, então posso diversas outras coisas; como se múltiplas possibilidades se abrissem a partir daí; enquanto nada falta, tenho medo de perder; não me arrisco, não me movimento - estagnação. No entanto, aquilo que está faltando, e como isso está faltando, é sempre singular para cada sujeito que se esforça para falar a verdade sobre a sua falta particular. O advento do desejo e a realização pelo sujeito da sua história envolve a aceitação da falta (castração), em toda sua irremediável radicalidade e particularidade.

Aliás, o desejo é sempre regulado exatamente porque trabalha com base numa falta, ou em outras palavras, porque é submetido à lei. Pode-se dizer que $o$ desejo está para a 'falta', assim como a angústia está para a 'falta de falta'. Para começar, isso significa dizer que o desejo da criança é mediado pelo Outro (mãe) que, mais ou menos, satisfaz suas demandas, fornecendo aquilo que lhe falta. $\mathrm{O}$ desejo, portanto, é uma relação do ser com a falta, na medida em que algo também falta à própria mãe - e aquilo que ela deseja é simbolizado pelo falo; assim, o desejo primordial da criança é tornar-se exatamente esse objeto perdido e imaginário desejado pela mãe, podendo assim satisfazê-la e, principalmente, garantir seu amor.

Em seu seminário 7 - a ética da psicanálise (1959-1960), Lacan vai aprofundar a elaboração sobre a falta, utilizando como fio condutor o conceito de das Ding (A Coisa). Tal conceito nos remete ao que podemos inferir sobre a falta em sua origem. Desta forma, Lacan esclarece que não se trata de um objeto primordial que foi perdido, mas que a falta encontra-se na origem do campo do desejo, funcionando como sua causa. A falta como mola do desejo. A falta lança o sujeito na dimensão desejante, característica do ser falante. A partir daí, o sujeito parte numa busca frenética e incessante pelo objeto perdido ou nunca antes encontrado (metonímia do desejo), visando a tão sonhada completude que 
tamponaria a falta angustiante, o buraco assustador, proporcionando ao sujeito paz, sossego e tranquilidade. Porém, nenhum objeto serve ou serve por muito tempo para tamponar a falta de que se trata. Esta busca pela completude (imaginária e ilusória) nunca alcançada funcionaria como motor para a maneira única e singular de cada um desejar e gozar. Ainda durante esta busca ocorrem, invariavelmente, encontros com objetos parciais que, exatamente por terem tal característica de parcialidade, produzem restos ou excessos com os quais o sujeito é impelido a lidar.

Uma vez que a falta é vivenciada como devastadora e, por isso mesmo, difícil de ser admitida pelo sujeito, este é impelido a buscar refúgio na fantasia. Fantasia que tem como função primordial aliviar a angústia, suturando a fenda ameaçadora e permitindo ao sujeito considerar-se mais inteiro e completo do que ele realmente é. O famoso objeto a - objeto causa do desejo - é o que, segundo Lacan, moveria o sujeito na busca pela completude. Propor-se como desejante é propor-se como falta de $a$ (Lacan, 1962-63/2005, p. 198). Quando a falta sai de cena; quando temos a sensação de que estamos plenos, completos, em outras palavras, quando achamos que nosso desejo foi finalmente realizado, então aí gozamos.

Na medida em que algo falta ao sujeito é que este se põe em movimento, se põe a criar. Porém, toda empreitada no sentido de apagar a falta, faz apenas surgir novas facetas da mesma. Nesta visada, a falta serve ao sujeito como um vazio fértil, responsável por mantê-lo em movimento. 


\subsection{Falo e desejo}

$O$ encontro entre o homem e a mulher é um encontro sempre faltoso e desvela o falo na posição de $-\varphi$. Ao se deparar com a negativização do falo, o homem se precipita na angústia e se dirige à mulher como objeto do desejo, acreditando que é do lado dela que ofalo se encontra.

(Coelho dos Santos \& Zeitoune, 2011, p. 99)

No título escolhido para esta parte do trabalho há um trocadilho: 'falo' pode ser lido tanto como um substantivo, representando o conceito psicanalítico que designa o órgão sexual masculino no sentido simbólico, como também um verbo, conjugado na primeira pessoa do presente do indicativo, representando uma das principais expressões da linguagem. Será exatamente este trocadilho que nos servirá de fio condutor para a construção de algumas articulações entre estes dois significados do mesmo termo (falo) e suas implicações em relação ao conceito de desejo que, na concepção psicanalítica, estão intimamente relacionados.

Começando pela primeira possibilidade de leitura - falo enquanto conceito psicanalítico - Freud argumenta em sua obra que as crianças de ambos os sexos conferem grande importância ao pênis, e que a descoberta de que alguns seres humanos não possuem tal órgão leva a importantes consequências psíquicas. Entretanto, o termo falo raramente aparece nos escritos freudianos, e quando surge, é utilizado como sinônimo de pênis. Lacan, por sua vez, vai preferir fazer uso do termo falo, ao invés de pênis, de forma a destacar o fato de que aquilo que se trata na teoria psicanalítica não é do órgão sexual masculino em sua realidade biológica, mas sim do papel que esse órgão ocupa na fantasia de cada sujeito. Assim, Lacan restringe o uso do termo 'pênis' para falar do órgão biológico, e utiliza o termo ‘falo’ para as funções imaginárias e simbólicas deste órgão.

Apesar desta distinção terminológica não estar presente na obra freudiana, reflexos dela aparecem, por exemplo, quando Freud estabelece uma equação simbólica entre o pênis e o bebê, como sendo aquilo que permite à menina abrandar sua inveja do pênis ('penisneid') a partir da possibilidade de dar à luz um filho. Fica claro, portanto, que Freud não está falando do órgão real biológico, 
mas de sua função simbólica. Pode-se argumentar que Lacan, neste caso, simplesmente formaliza e clarifica certas distinções que já estavam presentes na obra de Freud.

O falo, conceito que ocupa papel de destaque na teoria lacaniana do desejo, mais precisamente do nascimento do desejo, é definido, primeiramente, através de uma série de negações. Senão vejamos:

O falo é aqui esclarecido em sua função. O falo na doutrina freudiana não é uma fantasia, se cumpre entender por isto um efeito imaginário. Tampouco é, como tal, um objeto (parcial, interno, bom, mau, etc...) no que esse termo tende a apreciar a realidade interessada numa relação. Ele é menos ainda o órgão, pênis ou clitóris, que ele simboliza. (Lacan, 1966/2008, p. 267)

Ou seja, o falo, na leitura que Lacan faz de Freud, não é uma fantasia; não é um objeto; e, finalmente, não é um órgão anatômico, nem masculino, nem feminino. Lacan nos ensina, ao contrário, que o falo é um significante e o que ele significa é exatamente o desejo, mais precisamente, o desejo do Outro. O falo é um dos três elementos do triângulo imaginário que constitui a fase pré-edípica; um objeto imaginário especial que circula entre os outros dois elementos, a saber, a mãe e a criança. A mãe deseja o falo e a criança busca satisfazer esse desejo materno identificando-se com o falo. Já no complexo de Édipo, o pai intervém neste triângulo imaginário como um quarto elemento a favor da castração; ou seja, pela intervenção paterna, que torna impossível à criança se identificar com o falo imaginário que falta à mãe, o infante é salvo de um "labirinto onde o sujeito habitualmente se perde, e pode mesmo vir a ser devorado" (Lacan, 1956-57/1995, p. 194). A criança fica assim diante da castração. A renúncia por parte da criança de se identificar com o falo imaginário é o que vai pavimentar o caminho para seu relacionamento com o falo simbólico, ou seja, com o falo enquanto significante. A ideia lacaniana de que o falo é um significante tornou-se um dos elementos principais da sua teoria. Diz Lacan:

O fato de que o papel do falo como significante seja subjacente não deixa dúvida, já que foi necessária a análise para descobri-lo, mas nem por isso ele é menos essencial. (Lacan, 1956-57/1995, p. 194) 
Há ainda, na teoria lacaniana, uma distinção entre o Falo $(\Phi)$ - Phi maiúsculo - significante do gozo, da completude mítica, impossível de negativizar e o falo $(-\varphi)$, com phi minúsculo, representado negativado, significante do desejo, da falta e da castração. A falta, efeito da castração, é assumida pelo sujeito como tal no imaginário, sendo representada algebricamente como $-\varphi$, menos phi. (Braunstein, 2007, p. 94)

Em relação à segunda leitura possível - falo, do verbo falar - realmente só é possível ao sujeito desejar a partir de sua entrada na linguagem. Lacan sublinha o registro simbólico como aquele fundante do sujeito do desejo. O que interessa à Lacan é a fala enquanto linguagem, remetida a um Outro e situada na relação íntima que guarda com o falante. Sobre esta revalorização da linguagem, promovida por Lacan, Rudge (1998) faz a seguinte análise:

O trabalho de Jacques Lacan toma um lugar de destaque não só pela importância de sua contribuição na interpretação dos conceitos freudianos mas, principalmente, pela revalorização que promoveu do lugar da linguagem no âmbito da psicanálise que, em nosso entender, significou a retomada de uma posição que já estava implicada no empreendimento teórico freudiano (Rudge, 1998, p. 9)

Tomando este ponto de partida, Lacan vai mostrar que a linguagem manifesta uma demanda, para além do objeto intencionado e significado. A partir do advento da linguagem, ao mesmo tempo em que o corpo se desnaturaliza, perde-se a relação direta entre necessidade-objeto natural, o que impede qualquer possibilidade de satisfação (Rudge, 1998, p. 15). O desejo se articula na linguagem e se revela, por exemplo, nos lapsos e em todos os tropeços da fala. $\mathrm{O}$ campo de ação da psicanálise situa-se na fala, onde o inconsciente se manifesta, através de atos falhos, esquecimentos, chistes e de relatos de sonhos, enfim, naqueles fenômenos que Lacan nomeia como 'formações do inconsciente'. A isto se refere o famoso aforismo lacaniano de que o inconsciente é estruturado como uma linguagem.

$\mathrm{O}$ inconsciente estruturado como uma linguagem apresenta a linguagem tomada pelo sujeito como coisa já pronta e outorgada pelo Outro, para que, com este, o sujeito possa entrar em relação e suprir suas necessidades. A linguagem seria o que permite o surgimento do inconsciente, suas operações e 
transformações. Fora da linguagem, o inconsciente não existiria ou, pelo menos, seria impensável, irreconhecível e inapreensível. Daí a ideia de linguagem anterior ao sujeito e de sujeito como efeito de linguagem. Separada daquilo que representa, a linguagem aparece como uma organização autônoma em sua legalidade própria (Rudge, 1998, p. 80).

Para a psicanálise, somente há desejo, e consequentemente sujeito, a partir da linguagem. O desejo aparece como um elemento essencial da experiência humana, que emerge na linguagem e só por ela, revelando-se inconsciente, e só podendo ser contornado num processo interminável. A língua, não por acaso dita 'materna', é veiculada ao infante especialmente pela mãe no exato momento em que esta lhe presta os cuidados, de alimentação, higiene, etc., percebidos pela criança, simbolicamente, como gestos de amor. Realçando a importância de a mãe ser um ser falante, fato este que considera 'absolutamente essencial', Lacan (1957-58/1999) vai dizer o seguinte:

Não é apenas o pequeno roça-roça, os cuidados com água-de-colônia, que constituem uma relação com a mãe; é preciso que a mãe fale com a criança, todo o mundo sabe disso. (Lacan, 1957-58/1999, p. 406)

Esta passagem de infante a ser falante implica sempre em uma perda, que é própria da aquisição da linguagem. Ao mesmo tempo em que se ganha algo (linguagem) perde-se também algo. E de quê ordem é essa perda? Da ordem do gozo, é a resposta. $O$ gozo é a perda que se inscreve na medida em que houve a entrada no mundo simbólico. Como sujeito falante, ele não tem mais acesso a esse gozo. Este está perdido. “A aspiração do desejo se paga com uma cota de gozo", diz Braunstein (2007, p. 322).

Quando gozo eu não falo ('não há falo'), no máximo escuto (J'ouis), afirma Lacan. Não há falo na medida em que, quando gozo, o falo já não está mais ali, ereto, pois como se sabe, após o orgasmo há a chamada detumescência do órgão. Fazendo uso da homofonia existente entre as expressões francesas Jouis (goza) e J'ouis (eu ouço), Lacan (1966/1998, p. 836) diz que "viesse a Lei a ordenar 'Goza', o sujeito só poderia responder a isso com um 'Ouço', onde o gozo não 
seria mais do que subentendido". Podemos dizer, portanto, servindo-nos de outro trocadilho, que onde a fala (o falo) fracassa, aparece o gozo.

O estágio essencial da dialética do desejo (e do desenvolvimento humano em geral) tem lugar quando, pela entrada na ordem simbólica da linguagem e das convenções sociais, diga-se castração, a criança se submete àquilo que Lacan chamou de 'lei paterna' - o pai simbólico que diz 'não!' ('non du père') à união dela (criança) com a mãe (Outro) - (m)other. A lei simbólica comanda a renúncia de qualquer tentativa imaginária da criança de ser aquilo que falta à mãe, de ser o falo da mãe, separando, portanto, mãe e criança, gozo e desejo (Braunstein, 2007, p. 87) de uma vez por todas. $\mathrm{O}$ acesso do infante ao domínio da subjetividade, do discurso e, por que não, do desejo, se dá sempre à custa de uma perda, representada por uma renúncia de gozo - diga-se, castração. O medo da castração e da consequente submissão à lei paterna - lei simbólica - proporciona a possibilidade de expressão (fala) do sujeito, ao mesmo tempo em que divide o sujeito de si mesmo, instituindo e, simultaneamente, proibindo o inconsciente. $\mathrm{O}$ desejo inconsciente é, assim, fundamentalmente associado ao que é proibido - o incesto. Lacan articula lei, incesto e desejo da seguinte forma:

Esto es lo que hay que tener firmemente en mano - Freud designa en la interdicción del incesto el principio de la ley primordial, todos los demás desarrollos culturales sólo son sus consecuencias y sus ramales - y al mismo tiempo identifica el incesto con el deseo más fundamental ${ }^{9}$ (Lacan, 1959-60/2009, p. 84)

Na medida em que um sujeito é sujeito apenas por ter sido assegurada sua entrada no universo da linguagem, para ser, então, esse sujeito da linguagem, deve estar submetido ao significante. A respeito desta submissão ao significante, Lacan (1956/1992, p. 276) propõe que a psicanálise deveria ser a "ciência da linguagem habitada pelo sujeito", uma vez que, na perspectiva freudiana, o homem é o sujeito preso e torturado pela linguagem. Depreende-se daí que o sujeito não seria apenas um simples usuário de um código (lingüístico), mas, antes de mais nada,

\footnotetext{
${ }^{8}$ Não do pai.

${ }^{9}$ Isto é o que temos que ter firmemente em mãos - Freud designa na proibição do incesto o princípio da lei primordial, todos os demais desenvolvimentos culturais são apenas suas consequências e ramificações - e ao mesmo tempo identifica o incesto com o desejo mais fundamental.
} 
efeito de um discurso. $\mathrm{O}$ sujeito é falado antes de falar. O campo da linguagem, situado no campo do Outro, do grande Outro do simbólico, seria, portanto, anterior ao sujeito. Ou seja, o sujeito só pode se constituir a partir da linguagem, da ordem simbólica, sendo diretamente afetado e constituído por ela.

É somente a partir da entrada na linguagem, com a consequente submissão às regras ortográficas e gramaticais, ou, num sentido mais amplo, submissão à lei, que o sujeito ganha acesso ao campo do desejo e, ao mesmo tempo, do gozo. $\mathrm{O}$ processo de simbolização, responsável pela "intrusão da linguagem na carne", é o que vai conferir ao sujeito sua característica de falta a ser (manque à être), lançando-o nas veredas do desejo (Braunstein, 2007, p. 78). Na verdade, o gozo vem antes da lei, antes do desejo, porém não é possível chamar algo de gozo naqueles primeiros momentos de um ser mítico pré-linguístico. Somente a partir da instauração da lei (linguagem) é que podemos nos referir a alguma coisa anterior como gozo, sempre retroativamente. Só depois ('nachträglich') é possível afirmar que houve algo como uma 'perda de gozo', a partir, justamente, da entrada na linguagem. Tanto o gozo quanto o desejo dependem da lei (da linguagem) para existir; ou melhor, podemos inferir que os três surgem ao mesmo tempo no psiquismo: lei, gozo e desejo. Braunstein (2007, p. 77) esclarece que a linguagem é aquilo que funciona, ao mesmo tempo, como barreira e pré-condição ao gozo. A partir daí, podemos dizer que o gozo precisa da lei para transgredir, ao mesmo tempo em que e o sujeito precisa da lei (nome-do-pai) para desejar, ou seja, para desvincular-se do desejo e dos caprichos maternos. Sobre a importância da lei, Ambertín (2011, p. 61) nos lembra que "sin ley no hay qué burlar, sin ley... qué gracia tienen las cosas, tanto las establecidas como las interdictas?"10. Lacan (2009, p. 215) faz uso de uma passagem bíblica para expressar a mesmíssima ideia: "Era necesario que el pecado tuviese la Ley, dice san Pablo, para que pudiese devenir" 11 .

O pai simbólico não é um ser real, mas uma posição, ou melhor, uma função, que dá origem à expressão lacaniana função paterna. O pai, para a psicanálise, é aquele(a) (ou aquilo) que a mãe reconhece como importante para

\footnotetext{
${ }^{10}$ Sem lei não há o que se burlar, sem lei... que graça têm as coisas, tanto as estabelecidas como as proibidas?

${ }^{11}$ Era necessário que o pecado tivesse a Lei, disse São Paulo, para que pudesse advir.
} 
ela, quem ela nomeia de seu objeto de desejo, num reconhecimento que apenas pode ser conferido pela palavra, pelo discurso. Esta função não é outra senão a de impor a lei e regular o desejo no complexo de Édipo; a lei do princípio de prazer, que ordena ao sujeito 'gozar o mínimo possível', mantendo-o assim a uma distância segura da Coisa (Das Ding). Ao intervir na relação imaginária dual mãefilho(a), o Nome-do-Pai introduz uma distância simbólica necessária entre eles (Lacan, 1956-57), proibindo tanto o gozo da mãe quanto o da criança. Sobre esta operação simbólica, fundamental na constituição do sujeito, Valas (2001) diz o seguinte:

A interdição do incesto se dirige tanto à criança que não deve gozar da mãe, quanto à mãe que não deve tomar o seu filho como objeto de gozo. Paradoxalmente, é o amor do filho pelo pai que permite efetuar o ato na renúncia ao desejo pela mãe. (Valas, 2001, p. 42)

A função verdadeira do pai é, portanto, unir, e não colocar em oposição, o desejo e a lei. Nas palavras de Cottet (1989, p. 10), isso é o que "leva Lacan a considerar a lei não como uma coerção externa, mas como interna ao desejo, como limite interno do gozo. (...) É o amor pelo pai que serve, de alguma forma, de regulação, ao desejo". Aí está, de forma resumida, aquilo que Lacan chamou de “metáfora paterna”, ou seja, a substituição, no código do Outro, do desejo da mãe (DM) pelo Nome-do-Pai (NP), produzindo uma significação fálica para o sujeito. Como resultado desta substituição, o falo passa a assumir a função de significante da falta para o sujeito, tendo a impossibilidade do gozo da Coisa ou gozo do ser como significado. A castração significa que todo ser falante está sujeito à lei da proibição do incesto, devendo, portanto, renunciar ao primeiro e absoluto objeto de desejo, qual seja, a Mãe (Braunstein, 2007, p. 87).

Na metáfora do crocodilo com sua bocarra aberta, utilizada por Lacan para ilustrar o desejo da mãe (DM), este mesmo crocodilo é representado necessariamente regulado, de saída, por um pedaço de madeira - falo - dentro de sua imensa boca que impede, justamente, que esta se feche sobre o infante, devorando-o. Isso é o que nos possibilita falar da articulação existente entre os significantes ‘Desejo da Mãe' (DM) e 'Nome-do-Pai' (NP) na chamada 'metáfora paterna', que nada mais é do que a substituição do 'DM' pelo 'NP', operação 
psíquica importantíssima que tem como efeito salvar o sujeito da psicose. É somente a partir da intervenção do pai, intervenção esta que tem a função de articulação do desejo com a lei, que a criança pode ver-se livre dos desejos e caprichos maternos e, finalmente, constituir-se como sujeito desejante. Acompanhemos Lacan no momento em que destaca a importância do Nome-doPai para a estruturação do sujeito:

O pai simbólico é o nome do pai. Este é o elemento mediador essencial do mundo simbólico e de sua estruturação. Ele é necessário a este desmame (...). O nome do pai é essencial a toda articulação de linguagem humana. (Lacan, 1956-57/1995, p. 374)

Sabe-se que a perda da mãe freudiana é o caos para a criança, porém é dessa mãe que a criança precisa se separar. A falta desta separação, ou seja, sem castração, "somos mergulhados no excesso do real; (...) ficar apenas com ela (a mãe) é garantia da perda de si mesmo em uma alienação absoluta" (Vieira, 2012, p. 55). Do gozo impossível (do incesto) ao desejo submetido à lei, este é o árduo caminho a ser percorrido pelo sujeito. O incesto é lugar do vazio; lugar onde há gozo, porém não há sujeito. O incesto real não existe; no lugar do gozo, um vazio.

Ao barrar o acesso à mãe, o Nome-do-Pai representa exatamente esta impossibilidade, que pode ser chamada de lei do desejo. Neste mito familiar, no qual um pai-ladrão subtrai o gozo do menino, perde-se algo do gozo, mas ganhase um desejo (Vieira, 2011). Desta operação, algo resta. Nem todo gozo será trazido para o campo da lei - algo do gozo original restará, não sendo coberto pelo desejo. Portanto, isso resta; isso se mantém como um resíduo; a isso Lacan chamou de objeto $a$.

Quando o paciente de Freud diz: "Não é minha mãe”, entendemos que esta frase conjuga a lei e o desejo. Enquanto o desejo incestuoso afirma "é minha mãe", a lei que interdita insere um "não" radical que instaura a ordem da linguagem. A descoberta lacaniana implica, portanto, na produção de um novo estatuto de caracterização e uma nova compreensão da condição humana, na medida em que não é somente o homem que fala, mas, no homem e através do homem, isso fala ('ça parle’). $\mathrm{O}$ isso, devendo ser aqui compreendido como a estrutura da linguagem. A hipótese lacaniana, da anterioridade e autonomia do 
simbólico em relação à fala individual do sujeito, pode ser pensada a partir da linguagem e do simbólico como momentos necessários à produção e à constituição do humano, no sentido de que o simbólico funcionaria como o $a$ priori do homem. A partir da compreensão de que o ser humano situa-se para além do que lhe é biologicamente natural, no sentido de que, para constituir-se como sujeito, deve ocupar um lugar para além do ancoradouro biológico e passar a habitar o mundo da linguagem, percebemos que esta metamorfose, esta transmutação do natural ao cultural, do biológico ao simbólico, é o que nos possibilita afirmar que a psicanálise é a teoria do desejo na sua relação ao Outro.

A lei e o desejo recalcado são uma só e mesma coisa, ou seja, se por um lado, a lei impõe limites ao desejo, por outro, ela é também responsável, através da própria interdição, por causar o desejo (de outra coisa). A relação dialética entre desejo e lei é o que, precisamente, causaria o desejo; o que o desejo almeja é, essencialmente, transgredir (gozar), e para que haja transgressão, é necessário primeiro que haja proibição (lei). É como se a proibição induzisse ao pecado: $o$ fato do fruto ser proibido induziu Eva a cometer o pecado original de comê-lo. Vejamos como Lacan entende a questão da transgressão, articulando lei e gozo:

Llegamos en este punto a la fórmula según la cual una transgresión es necesaria para acceder a ese goce y que (...) para esto muy precisamente sirve la Ley. La transgresión en el sentido del goce sólo se logra apoyándose sobre el principio contrario, sobre las formas de la Ley. ${ }^{12}$ (Lacan, 1959-60/2009, p. 214)

Uma vez que o desejo em questão continua a ser tanto inconsciente como desejo de algo que está essencialmente perdido, há um limite para o que pode ser dito, conhecido e alcançado em relação ao mesmo. Segundo Lacan (1966) há uma incompatibilidade essencial entre desejo e fala, e a verdade só pode ser dita pela metade. Mais precisamente, tudo o que pode ser propriamente dito ou apresentado do objeto ausente do desejo é simplesmente que o mesmo está faltando: a fala perde-o. No domínio do discurso, o falo não é um objeto perdido que poderia ser recuperado ou reconquistado, mas simplesmente um significante para o que está faltando, como tal. O falo simbólico não significa nada em especial, somente que

\footnotetext{
${ }^{12}$ Chegamos, neste ponto, à fórmula segundo a qual uma transgressão é necessária para alcançar esse gozo e que (...) para isso muito precisamente serve a Lei. A transgressão, no sentido do gozo, só pode ser alcançada apoiando-se sobre o princípio oposto, sobre as formas da Lei.
} 
o objeto do desejo figura apenas como uma falta. A partir desta perspectiva, o objeto do desejo (que é sempre singular para o sujeito) pode aparecer como um paradoxal e evasivo não-objeto, como algo que 'objetiviza' a ausência ou impossibilidade de um objeto. Um objeto especial, que não pode ser apreendido nem representado, chamado por Lacan de "objet petit $a^{13}$.

Importante marcar que esta função do falo apenas se faz possível graças ao que podemos chamar de submissão; uma submissão 'apaixonada' à ordem simbólica ou, em outras palavras, às leis da linguagem. O falo ocupa, portanto, sua posição privilegiada em função de uma perda, e esta perda é representada por Freud como castração. A linguagem em si, sempre responde a uma falta; nós aprendemos a simbolizar de maneira a expressar nossa sensação de que algo está faltando - seja comida, aconchego ou segurança. Nós começamos a utilizar a linguagem para dizer aos nossos pais que nós não estamos mais 'completos'. É através desta submissão à ordem simbólica, e por estar separado do organismo, que o falo passa a poder significar também este objeto especial da teoria lacaniana: o objeto $a$ - objeto irremediavelmente perdido, que tem a função especial de causa de desejo. Lacan (1957-58/1999, p. 405) vai qualificar o falo ainda como 'significante do desejo' e 'significante particular', o qual, a partir de um lugar privilegiado, designará o conjunto dos efeitos do significante.

\subsection{Objeto do desejo}

If I say that an a is what causes desire, this means that it is not its object. It is not its complement, direct or indirect, but only this cause that. ${ }^{14}$ (Lacan, 1974-75, p. xxvi)

Para Lacan, assim como para Freud, o desejo é desejo do sujeito por um objeto fundamentalmente perdido. A leitura freudiana indica que qualquer busca por um objeto é, na verdade, uma tentativa de reencontrá-lo. Na visão lacaniana,

\footnotetext{
${ }^{13}$ Objeto pequeno $a$.

${ }^{14} \mathrm{Se}$ eu digo que um $a$ é aquilo que causa desejo, isto significa que este não é seu objeto. Este não é seu complemento, direto ou indireto, mas apenas isto causa aquilo.
} 
no entanto, o objeto do desejo está localizado antes do desejo, funcionando exatamente como sua causa. Partindo deste princípio - do objeto como anterior ao desejo - sempre que desejamos algo, esse algo nos remete a este objeto especial, chamado por Lacan de 'objeto pequeno a' - ou simplesmente 'objeto a'. Em uma definição sucinta e esclarecedora deste importante conceito psicanalítico, Vieira (2008, p. 55) diz que "o objeto $a$ é o que, no objeto, nos dá vida". Ou seja, aquele "algo mais" do qual não conseguimos falar.

Lacan pontua que o objeto $a$ tem a ver com a relação entre o sujeito e o Outro. "É a partir do Outro que o $a$ assume seu isolamento, e é na relação do sujeito com o Outro que ele se constitui como resto" (Lacan, 1962-63/2005, p. 128). Deste encontro do sujeito com o Outro haveria uma divisão do sujeito e clivagem do Outro, mais a produção de um resto que é, precisamente, o objeto $a$ resto da operação de enlace da lei com o desejo (castração simbólica), ou seja, gozo perdido. Sobre este "algo" inefável que se perdeu, representado pelo $a$, Vieira (2008, p. 53) vai dizer que "se situa no objeto de nossa afeição como marca de um indizível e assegura que é impossível esgotar pela nomeação o que se perdeu".

Este resto instituinte do sujeito seria, portanto, a causa do seu desejo, aquilo que o poria em movimento. A proposição lacaniana do objeto $a$ envolve a concepção de um "objeto especial", indizível, que coloque em movimento o desejo do sujeito. Vem daí a famosa recomendação lacaniana de que o analista deve situar-se como semblante de objeto a, causando o desejo do analisando. Este objeto bastante perseguido - mas que nunca pode ser alcançado - é um nada, impossível de ser nomeado. Diz Lacan (1954-55/2010):

O desejo, função central em toda experiência humana, é desejo de nada que possa ser nomeado. É, ao mesmo tempo, este desejo que se acha na origem de qualquer espécie de animação. (Lacan, 1954-55/2010, p. 302)

Há, portanto, somente um único objeto do desejo - objeto $a$ - que é representado por uma variedade de objetos parciais, em diferentes pulsões também parciais. Objeto metonímico por excelência, o objeto $a$, é, na verdade, um 'lugar', ocupado transitoriamente por diversos outros objetos. O objeto $a$ não 
é o objeto na direção do qual o desejo se inclina, mas sim o objeto causa de desejo. Garcia-Roza (2002, p. 192) nos lembra que o desejo humano é desejo de desejo, e não desejo por um objeto qualquer - o objeto do desejo humano é outro desejo.

O objeto em questão não se reduz a um objeto qualquer do mundo sensível, mas é um objeto inapreensível, não representável, do registro do real. Os objetos parciais, que são os cinco que veremos a seguir, não são o objeto $a$, eles apenas o representam na qualidade de algo que cai do corpo, instituindo zonas erógenas. $\mathrm{O}$ objeto $a$, esse "algo" que cai, que se desprende da ordem simbólica como resto.

Ele pode ser representado sob a forma de fragmentos parciais do corpo, redutíveis a quatro: o cíbalo, o mamilo, a voz e o olhar; e Lacan ainda inclui o falo, o quinto elemento, destacando-o como o mais ilustre dos objetos a (Lacan, 1962-63/2005, p. 103). São objetos anteriores à constituição do status do objeto comum, comunicável e socializado. O objeto $a$ nos remete exatamente a esta impossibilidade de representação, algo da ordem do inominável, fora do significante, lugar de ausência - "cinco formas de perda", segundo Lacan (1962$63 / 2005$, p. 104), que representam os principais momentos de aparecimento do sinal de angústia.

Fazendo um paralelo com a linguagem, esta também compreende essencialmente um buraco, um vazio, uma falta que a fala contorna, faz borda e tenta recobrir, porém sem jamais conseguir obturá-la. Assim, podemos perceber algumas características semelhantes entre a linguagem e o objeto $a$.

Miller (2011, p. 195), situa o objeto $a$, como um 'amboceptor entre desejo e gozo', e embasa sua afirmação em duas proposições trazidas por Lacan ao longo de sua obra, que o definem tanto como 'mais-gozar' como 'causa do desejo'. Enquanto 'causa do desejo', o objeto $a$ é vazio em si; um espaço vazio, circundado por uma borda $(a)$; um "nada" que, por ser nada, pode abrigar muitos objetos; não infinitos, mas certamente muitos; é justamente da relação com este objeto, que simboliza a falta, o vazio, que se trata no campo do desejo. Pode-se dizer que no campo do desejo não é da relação com um objeto que se trata, mas sim da relação com uma falta - objeto $a$ enquanto símbolo da falta. É o objeto $a$, 
que, de alguma forma, se articula ao vazio do desejo, como uma espécie de compensação pelo sofrimento da castração. Assim, uma das funções do $a$ seria exatamente esta de suturar a fenda aberta pela entrada do sujeito na ordem simbólica. Em sua outra vertente, - 'mais-gozar', - o objeto $a$ pode ser tomado como um excedente de gozo advindo da introdução do simbólico no real (entrada na linguagem). Nas palavras de Miller (2011, p. 195), um mediador entre gozo e desejo.

Com o propósito de materializar um pouco deste conceito tão etéreo como o $a$, tomamos aqui a liberdade de propor uma possível correlação entre este objeto especial da psicanálise e o órgão genital feminino. Partamos da seguinte passagem de Lacan, da qual esta ideia pode ser depreendida:

E por que nos espantarmos com isso? Nosso esquema do lugar vazio na função do desejo permite-lhes ao menos situar o paradoxo de que se trata, e que se define assim: o lugar, a morada do gozo, encontra-se normalmente - posto que naturalmente - situado num órgão que tanto a experiência quanto a investigação anatomofisiológica ensinam, da maneira mais segura, ser insensível, no sentido de que sequer poderia ser despertado para a sensibilidade, em razão de sua inervação. O lugar supremo do gozo genital é um local - o que não é mistério - em que se podem derramar dilúvios de água fervente, levada a uma temperatura insuportável para qualquer outra mucosa, sem provocar reações sensoriais imediatas (Lacan, 1962-63/2005, p. 83).

Ambos - objeto $a$ e vagina - são 'furo'; são, ao mesmo tempo, causa de desejo e gozo. Na passagem acima, Lacan chama a vagina, com muita propriedade, de 'morada do gozo', lugar supremo do gozo genital, lugar onde os dois 'gozos' - secreção vaginal e sêmen - se encontram. Miller (2011, p. 196) vai dizer que o objeto $a$ é um "artifício teórico" que funciona também como uma unidade de gozo. Conforme veremos, gozo e angústia estão intimamente relacionados (Lacan, 1962-63/2005, p. 91) e o que 'preenche', tanto o a quanto a vagina, é gozo.

Avancemos. Tanto o objeto $a$ como a vagina têm íntima relação com o vazio, com a falta, e estão relacionados ao inapreensível registro do real. O próprio desenho da letra $a$ lembra a vagina, na medida em que se assemelha a um buraco, um espaço vazio circunscrito. Sabe-se que Lacan considera o objeto $a$ como uma de suas principais contribuições à psicanálise, nada mais justo, 
portanto, do que prestar uma homenagem velada a este objeto teórico da sua criação. O quadro 'A Origem do Mundo' ('L'Origine du Monde') do artista francês Gustave Courbert (1866), após passar pelas mãos de diversos proprietários ilustres, em diferentes países, foi parar na parede da sala da casa de campo de Jacques Lacan, escondido sob outro quadro de madeira, recurso também utilizado por outros proprietários e que nos remete novamente ao objeto $a$, que se apresenta sempre escondido, camuflado, nunca aparente. Vejamos o quadro:

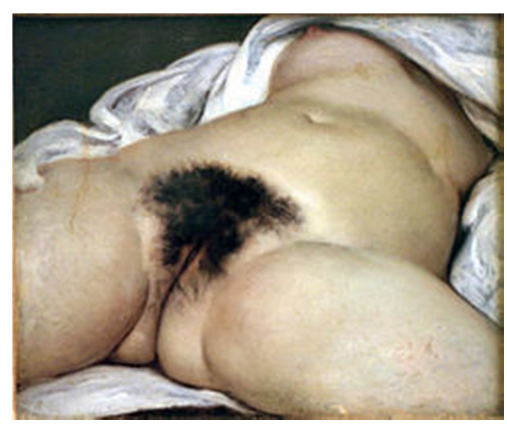

Figura 1 - Quadro "A Origem do Mundo" (Courbert, 1866)

Em relação ao "mais ilustre dos objetos $a$ " - o falo (Lacan, 1962-63/2005, p. 103) - podemos inferir ainda que o falo real (pênis) seria, de fato, o mais ilustre dos objetos convidados a preencher, mesmo que momentaneamente, o espaço vazio da vagina. Em seu seminário de 1960-61 - 'a transferência' - Lacan articula o objeto a com o termo grego agalma ${ }^{15}$, que ele retira do Banquete de Platão. Assim como o agalma é um objeto precioso escondido dentro de uma caixa relativamente sem valor, também a vagina possui uma estreita ligação com o significante "caixa", sendo que uma de suas principais designações na língua portuguesa - boceta - consta definida no Dicionário Aulete, além de 'a vulva', como 'caixa pequena, geralmente cilíndrica ou oval'.

15 s. m. || na antiga Grécia, objeto artisticamente ornamentado. || Ornato, enfeite. || Oferendas colocadas nos templos dos deuses. $\|$ F. gr. Agalma, pelo lat. agalma. $\underline{\text { http://aulete.uol.com.br/agalma\#ixzz2B4fcZfaB }}$ 


\subsection{Grafo do desejo}

Ele (grafo do desejo) nos servirá aqui para apresentar onde se situa o desejo em relação a um sujeito definido por sua articulação pelo significante. (Lacan, 1966[1960]/1998, p. 819)

O grafo do desejo ('graphe du désir') é uma representação topográfica, inventada por Lacan, para demonstrar graficamente o que seria a estrutura do desejo em sua relação com o significante, situando, para tal finalidade, os

principais elementos constituintes do psiquismo, dentre eles: o desejo, a linguagem e o inconsciente. Faremos uma breve apresentação introdutória das principais etapas de construção do grafo de Lacan, buscando através delas construir algumas articulações relacionadas aos conceitos de desejo, gozo e angústia, tema deste trabalho.

Lacan desenvolve primeiramente seu grafo do desejo no Seminário 5 (195758/1999) e vai fundamentá-lo na oposição entre necessidade-demanda-desejo, tratando das relações do sujeito mítico da necessidade, do atravessamento da demanda e de seu mais além, o desejo. Com sua invenção, o mestre francês buscava dar conta da experiência analítica, dando mais ênfase à lógica do que à intuição.

O grafo é apresentado de diversas formas na obra de Lacan, embora o formato mais conhecido apareça no texto 'Subversão do sujeito e dialética do desejo no inconsciente freudiano' (Lacan, 1966[1960]/1998). Nesta comunicação, Lacan constrói seu grafo do desejo em quatro etapas, o que não significa dizer que haja qualquer sucessão que pudesse remeter à ideia de um desenvolvimento genético. Considerando que o gráfico sempre existe como um todo, os estágios intermediários não têm como pretensão mostrar nenhuma evolução ou desenvolvimento temporal, ao invés disso, trata-se de recurso pedagógico utilizado por Lacan para ilustrar a estrutura do grafo completo.

A primeira destas etapas, chamada de 'célula elementar' (Figura 2), é constituída pelo 'traçado do ponto de estofo', configurando a relação do sujeito 
com o significante. A linha horizontal (SS') representa o movimento diacrônico da cadeia significante, enquanto que a seta em forma de ferradura - vetor dos significados - diz respeito à intencionalidade do sujeito. Os dois pontos de interseção destas duas linhas indicam a característica retroativa da mensagem.

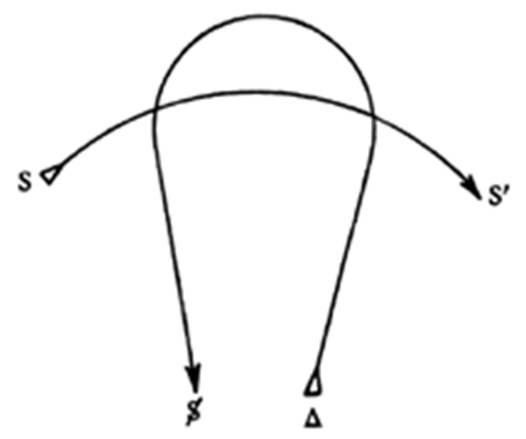

Figura 2 - Grafo do desejo (célula elementar)

Na segunda etapa de construção do gráfico (Figura 3), estas interseções estão identificadas por A e $\mathrm{s}(\mathrm{A})$. O ponto marcado com $\mathrm{s}(\mathrm{A})$ é o chamado ponto de estofo ('point de capiton'), onde a significação (mensagem) se constitui como produto acabado, determinado retroativamente pela pontuação particular efetuada pelo Outro (A). "Ali se articula o que chamamos ponto de basta, pelo qual o significante detém o deslizamento da significação, de outro modo indefinido", diz Lacan (1966[1960]/1998, p. 820).

Voltando à célula elementar do grafo (Figura 2), o sujeito mitológico prélinguístico da pura necessidade, indicado por um triângulo, deve atravessar os desfiladeiros do significante (SS`) para constituir-se como sujeito dividido (\$), inscrito na linguagem. Desta forma, o grafo visa demonstrar também como a demanda do sujeito vê-se profundamente modificada pelo efeito da passagem da necessidade através da cadeia significante.

O sujeito barrado/dividido (\$), que também pode ser entendido como sintoma, adviria, portanto, como consequência desta intervenção do 'sujeito mitológico pré-linguístico' (S1) no saber constituído dos outros significantes, na medida em que eles já estão lá, articulando-se entre si. Nesse trajeto do triângulo ao $\$$, percorrido por um sujeito mítico que a partir de uma necessidade parte(-se) 
em busca do objeto de sua satisfação, surge algo definido como uma perda, mais precisamente, perda de gozo, representada por Lacan pelo objeto a, causa do desejo e, ao mesmo tempo, objeto da angústia.

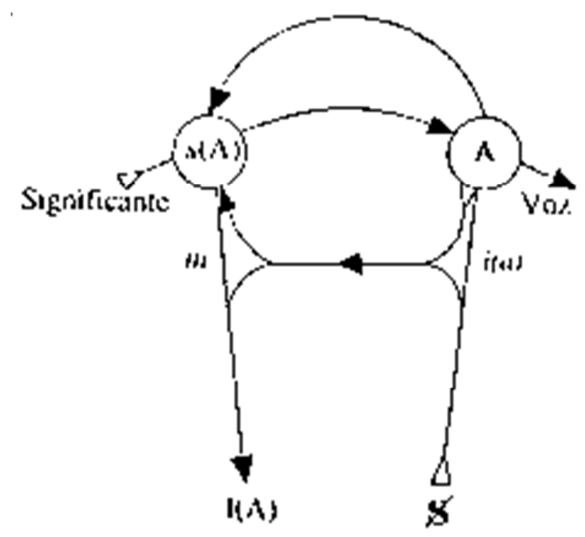

Figura 3 - Grafo do desejo (2ª etapa)

Ainda na segunda etapa (Figura 3), Lacan propõe uma modificação no grafo. A partir desse momento lógico, o lugar do sujeito mítico da pura necessidade passa a ser ocupado pelo sujeito falante e, portanto, faltante (\$). Este sujeito barrado, sedento por recuperar seu gozo perdido, recebe do Outro (A), 'tesouro dos significantes', um significante capaz justamente de restituir ilusoriamente [i(a)] a completude da qual fora arrancado. No estádio do espelho, o sujeito captura e se fixa nesta identificação com a imagem do outro [i(a)], o semelhante, que é sua própria imagem. Este fenômeno tem participação na identificação primária do sujeito, a qual se sustentaria, precisamente, a partir de uma relação de dependência alienante com o Outro (mãe). Prova disto, segundo Dor (1989), seria o olhar da mãe, indispensável para a instauração desse processo identificatório.

O terceiro momento da construção do grafo (Figura 4) nos remete visualmente a uma interrogação. Um ponto de interrogação surge a partir do lugar do Outro (A), representando o enigma angustiante que gira em torno do seu desejo (desejo do Outro): Che vuoi? Que queres? O que queres de mim? No processo de apreensão da linguagem o sujeito confronta-se com o enigmático desejo do Outro, 
sem ter a mínima ideia de que objeto representa para esse desejo, que segundo Lacan, seria opaco e obscuro. Isso angustia.

Para proteger-se da angústia causada por esse enigma, o sujeito responde ao desejo do Outro construindo sua fantasia, inserida no grafo com a notação $(\$ \diamond a)$, na qual o $a$ seria o objeto ilusório que completaria a falta estruturante do sujeito. Fantasia enquanto ilusão de completude; véu que encobre a falta no Outro, fazendo crer que este Outro, por ser completo, nada deseja. Cito Lacan (1966/1998):

O grafo inscreve que o desejo é regulado a partir da fantasia, assim formulada de maneira homóloga ao que acontece com o eu em relação à imagem do corpo. (Lacan, 1966/1998, p. 831)

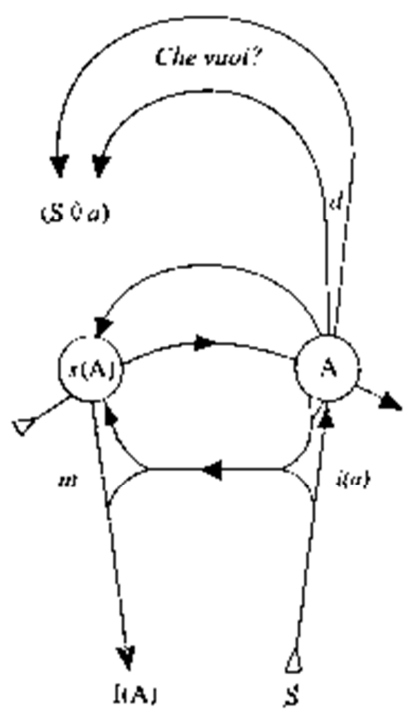

Figura 4 - Grafo do desejo (3a etapa)

Na versão completa do gráfico (Figura 5), os vetores horizontais que vão do lado esquerdo para o lado direito do gráfico representam os movimentos da demanda dirigida ao Outro ('tesouro dos significantes'), tanto a nível consciente (andar de baixo) quanto inconsciente (parte de cima). No grafo completo, não há apenas uma, mas duas cadeias significantes. A cadeia mais abaixo do gráfico - do significante à voz - representa a cadeia significante consciente, ao nível do enunciado, enquanto que a cadeia mais acima do gráfico, que vai do gozo 
('jouissance’) à castração, é a cadeia significante no inconsciente - o nível da enunciação. A estrutura é desta maneira duplicada, sendo a parte de cima estruturada exatamente igual à parte de baixo.

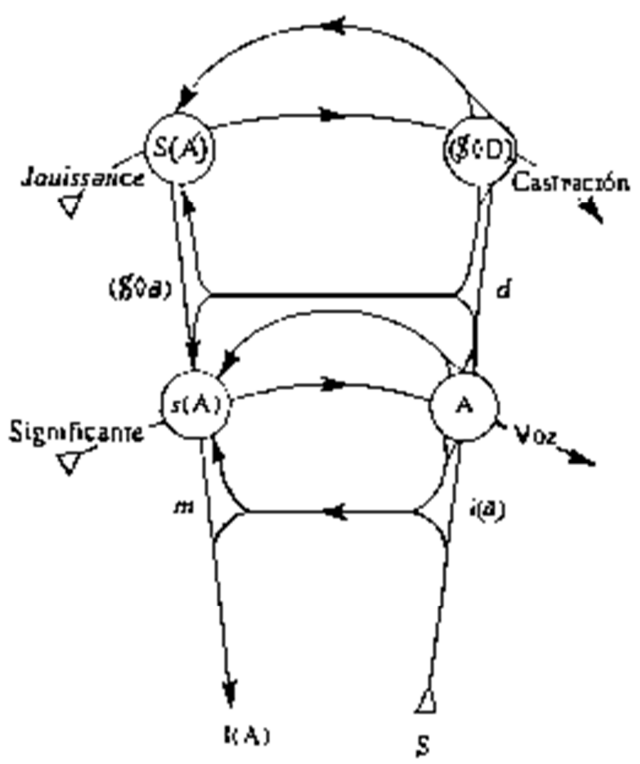

Figura 5 - Grafo do desejo (completo)

Assim, o grafo busca demonstrar que "uma demanda pode persistir no sujeito, numa escansão articulada, sem que nenhuma intenção consciente a sustente" (Dor, 1989, p. 184). O autor conclui ainda que se o inconsciente é o discurso do Outro e é estruturado como uma linguagem, então este mesmo inconsciente é capaz de fazer subsistir o discurso do Outro no discurso do sujeito. Em outras palavras, o discurso do Outro funcionaria como o inconsciente do sujeito.

No andar superior do grafo, o desejo $(d)$ é localizado no trajeto entre A e (\$ $\diamond \mathrm{D})$, indicando o percurso que se origina no Outro (A) e passa pela relação fundamental que o sujeito mantém com sua demanda, representada pela pulsão (\$ $\diamond$ D). Dor (1989) vai explicar que no ponto da mensagem (lado esquerdo do grafo), a reconstituição interpretativa faz surgir uma ausência de significante no Outro, $\mathrm{S}(\mathrm{A})$, marcando assim sua falta a ser. Em outras palavras, podemos dizer 
com André (1998) que a significação resultante do jogo das pulsões parciais é faltosa. Há um significante que sempre falta e, a partir da percepção dessa falta no Outro, o falo assume sua função de significante. Um significante, segundo o autor, paradoxal que vai assumir uma função dupla: ao mesmo tempo em que proíbe o gozo, por outro lado o permite. Esta é a mesma ideia contida na célebre assertiva de Lacan: "A castração significa que é preciso que o gozo seja recusado, para que possa ser atingido na escala invertida da Lei do desejo" (1966[1960]/1998, p. $841)$.

Na cadeia inconsciente do grafo (parte superior) a mensagem é fechada em um significante que especifica a falta de significante no Outro, ao passo que na cadeia inferior o Outro (A) aparece como 'tesouro dos significantes', ou seja, ilusoriamente completo.

No mesmo texto - 'Subversão do sujeito e dialética do desejo no inconsciente freudiano' (1966[1960]/1998) -, Lacan inscreve o gozo na topografia do grafo do desejo. Na parte superior do grafo, o gozo (jouissance) aparece indicando justamente essa falta no Outro $\mathrm{S}(\mathrm{A})$ ). S(A barrado) é a marca da interdição do gozo infinito, efeito do significante (castração). Este é o gozo fálico, relacionado à castração enquanto falta. $\mathrm{O}$ gozo fálico é localizado no grafo no nível de um vetor que vai de $\mathrm{S}(\mathrm{A})$ - falta no Outro - seguindo em direção a (\$ $\diamond$ D), representando a pulsão e a demanda do Outro. Para nos auxiliar na compreensão desta dinâmica, passo a citar Braunstein (2007):

Se o gozo tem a ver com a pulsão é na medida em que a pulsão deixa um saldo de insatisfação que estimula a repetição, e é nesta medida que a pulsão é historizadora, já que insatisfaz. (Braunstein, 2007, p. 63)

Portanto, o gozo é "do Outro" e ao mesmo tempo opera no nível de uma pulsão. Articulando gozo e pulsão (de morte), Braunstein (2007) dirá que o gozo é, de fato, a satisfação de uma pulsão - a pulsão de morte.

O reconhecimento da falta no Outro produz uma fantasia no inconsciente do sujeito. Nesta fantasia, o objeto representa justamente aquilo que o sujeito imagina faltar no Outro. A fantasia neurótica, representada por Lacan através do 
matema $(\$ \diamond \mathrm{a})$, aparece no grafo do desejo como a resposta do sujeito para o enigmático desejo do Outro, uma forma de responder a questão sobre o que o Outro quer de mim? (Che vuoi?). Lacan vai elaborar no seminário 10 sua afirmação da existência de uma relação essencial entre a angústia e o desejo do Outro (1962-63/2005), a qual a fantasia busca temperar, tornando as coisas mais palatáveis.

A mãe, enquanto Outro primordial, encontra-se proibida de tamponar sua falta utilizando a criança para tal fim. Assim, o Outro aparece como interditado (barrado). No grafo, Lacan posiciona o gozo exatamente no lugar desse Outro barrado - S(A) -, mesmo local onde localiza também o supereu, que ordena o sujeito a gozar, Goza! Lacan repete várias vezes o paradoxo segundo o qual, ao mesmo tempo em que o supereu proíbe e pune, ele também exige que o sujeito experimente o gozo. "Nada força ninguém a gozar, senão o supereu" (Lacan, 1972-73/1985, p. 11), diz o psicanalista francês. 


\section{Entre gozo e desejo: angústia}

Para apreendê-lo, será preciso retomarmos as coisas no ponto em que as deixei neste quadro, dizendo-lhes que a angústia é o meio-termo entre o desejo e o gozo.

(Lacan, 1962-63/2005, p.197)

A angústia - palavra que, em sua origem, remete às ideias de 'aperto', 'estreiteza' e 'sufocamento' - é reconhecida há bastante tempo na psiquiatria como um dos sintomas mais comuns presentes nos transtornos mentais. As descrições psiquiátricas da angústia geralmente referem-se tanto a fenômenos psíquicos (apreensão, preocupação) como corporais (falta de ar, palpitações, tensão muscular, fadiga, suor, etc.). A classificação psiquiátrica também faz distinção entre estados de 'angústia generalizada', quando uma angústia flutuante está presente na maior parte do tempo, e os 'ataques de pânico', que são caracterizados por episódios intermitentes e agudos de angústia.

Trazendo a discussão para o campo psicanalítico, o termo alemão empregado por Freud - 'angst' - pode englobar tanto as significações psiquiátricas como também as conceituações técnicas propostas pelo pai da psicanálise, em diferentes momentos de sua obra. Importante destacar que os termos 'angústia' e 'ansiedade' são utilizados indistintamente na literatura psicanalítica, sendo considerados sinônimos. O próprio 'Dicionário Aulete de Língua Portuguesa', em sua primeira acepção da palavra 'angústia', faz constar 'ansiedade intensa', demonstrando a íntima ligação entre os dois termos. Embora alguns autores façam questão de marcar eventuais diferenças sutis de significado, optamos, neste trabalho, por tratar 'angústia' e 'ansiedade' como sinônimos, substituindo nas referências bibliográficas consultadas o termo 'ansiedade' por 'angústia', nosso preferido. A propósito, 'angoisse’ foi o termo utilizado nas edições francesas da obra de Freud, no lugar do alemão 'angst', sendo fácil perceber a presença do mesmo radical - 'ang' - também presente em 'angústia'. Para Freud, a angústia é um afeto. 
Encontramos na obra freudiana, três tempos da construção psicanalítica do conceito de angústia. A primeira teoria (1895) é aquela implicada na conceituação das neuroses atuais: neurastenia e neurose de angústia. Nelas, a angústia é resultado da transformação de energia sexual somática, sem a participação do psiquismo. A energia sexual somática deve ser representada psiquicamente, por afeto e ideias, para buscar satisfação por uma ação específica. Nas neuroses atuais isso não ocorre, pois não existe processamento psíquico dessa tensão somática. Ela é então descarregada como angústia. Note-se que neste primeiro momento Freud ainda não fala de libido, que é de ordem psíquica. Nos termos de Freud, lemos o seguinte:

A neurose de angústia, por outro lado, é produto de todos os fatores que impedem a excitação sexual somática de ser psiquicamente elaborada. (Freud, 1895[1894]/1996, p. 110)

Num segundo momento (1909), conforme veremos mais detalhadamente a seguir, Freud passa a considerar a angústia como transformação de um excesso de libido, que não teria sido devidamente escoado, acumulando-se e, em seguida, transbordando para o corpo. Nesta concepção, é a energia libidinal, psíquica, que se transforma em angústia, mais precisamente, em histeria de angústia. Este transbordamento seria, portanto, o que estaria por trás dos sintomas corporais observados na angústia, como falta de ar, taquicardia, sudorese, etc., os quais Freud faz questão de relacionar com as manifestações corporais observadas durante o ato sexual, estabelecendo, desta forma, uma íntima ligação entre libido (energia sexual psíquica) e angústia. Nesse momento da construção teórica freudiana, o recalque das pulsões sexuais passa a ser apontado como motivo da irrupção de angústia.

Na chamada 'virada de 1926', quando publica 'Inibição, sintoma $e$ angústia' (1926/1996), Freud passa a defender o fenômeno da angústia enquanto reação a uma experiência traumática, de perda, de falta e de desamparo, que é consentânea à situação de total dependência do infante, e à sua prematuridade, ao nascer tão pouco equipado para a sobrevivência. Nesta terceira concepção, é a angústia que passa a presidir o recalque, portanto, e não o contrário, como 
pensava Freud anteriormente. Sobre esta guinada no pensamento freudiano, Rudge (2009) afirma o seguinte:

Recalca-se exatamente aquilo que provoca angústia, sejam pensamentos, desejos ou percepções. A angústia não é mais gêmea da sexualidade, mas sim do desamparo. (Rudge, 2009, p. 58)

O papel do recalque no surgimento da angústia também pode ser observado a partir de três momentos distintos. Primeiramente, nos casos das neuroses atuais, não é o recalque a causa da angústia, mas a falta de vida sexual, por qualquer motivo (fulano está na prisão solitária, por exemplo). Em um segundo momento, o recalque passa a ser o pivô do surgimento da angústia, pois atuaria liberando o afeto (libido) da representação (ideia) recalcada. Finalmente, Freud vai apresentar o recalque não como causa, mas como consequência da angústia, que passa a ser fundamentalmente 'angústia de castração'. O recalque, portanto, deixa de ser aquilo que cria angústia - a angústia já estava ali, mais cedo.

O psicanalista francês, Jacques Lacan, em seu 'retorno a Freud', vai dedicar considerável parte de sua obra ao estudo do fenômeno da angústia, não é à toa que nomeia um de seus seminários (sem. 10) de "A angústia" (1962-63/2005). Porém, enquanto Freud relaciona a angústia à perda do objeto (ou castração), Lacan, em sua releitura, vai 'além da angústia de castração' (cap. IV, sem. 10) e passa a argumentar que a angústia 'não seria sem objeto' ('n'est pas sans objet'), e ocorreria, justamente, através da relação com a proximidade desse objeto, a partir da sua presença - e não de sua ausência. Esta leitura lacaniana nos indica, portanto, que a angústia - elevada à condição de único afeto que não engana surgiria quando algo aparece ocupando o lugar da falta, do vazio, do lugar representado pelo objeto faltoso do desejo - o objeto $a$. 


\subsection{Primeira teoria da angústia}

O que claramente desejamos é encontrar algo que nos diga o que é realmente a angústia, algum critério que nos permita distinguir dos falsos os verdadeiros enunciados a respeito dela. Mas isto não é fácil conseguir. A angústia não é assim um assunto tão simples. (Freud, 1926[1925]/1996, p. 131)

Em um primeiro momento, Freud argumenta que a angústia neurótica poderia ser simplesmente resultado da transformação daquilo que chamou de 'energia sexual somática', que não teria sido adequadamente descarregada, nos casos das chamadas 'neuroses atuais': neurastenia e neurose de angústia. Ou seja, na teoria freudiana das neuroses atuais, a angústia começa a ser pensada como resultante de um acúmulo de energia sexual, consequência de uma falta de escoamento adequado. Este fenômeno ocorreria, principalmente, nos casos de abstinência sexual, como a das virgens insatisfeitas, e de coito interrompido. Nas palavras de Freud (1895[1894]/1996):

Todas essas indicações - de que estamos diante de um acúmulo de excitação; de que a angústia, provavelmente correspondente a essa excitação acumulada, é de origem somática, de modo que o que se está acumulando é uma excitação somática; e ainda, de que essa excitação somática é de natureza sexual (...) (Freud, $1895[1894] / 1996$, p. 108-109)

Para ilustrar, os sintomas corporais típicos da angústia, como dispneia, respiração acelerada, tensão muscular, suor, tremores e palpitações, são mencionados por Freud como sendo apenas 'substitutos da ação específica omitida posteriormente à excitação sexual' (1895[1894]/1996, p. 112). A ideia de transformação da excitação sexual somática em angústia, sem intervenção do psiquismo, deu origem ao que chamamos de primeira teoria angústia. Este afeto primordial da psicanálise é problematizado neste momento com ênfase em seu aspecto econômico, sendo decorrente de uma espécie de transbordamento da excitação sexual que não encontrou escoamento adequado pela via sexual. Relacionando angústia e sexualidade, Freud (1894/1996) diz o seguinte: 
Logo ficou claro para mim que a angústia de meus pacientes neuróticos tinha muito a ver com a sexualidade; e me chamou especialmente a atenção a certeza com que o coitus interruptus praticado numa mulher conduz à neurose de angústia. (Freud, 1894/1996, p. 235)

\subsection{Segunda teoria da angústia}

Numa outra perspectiva, quando trata das psiconeuroses (em oposição às neuroses atuais), Freud defende a tese de que a angústia decorre do recalque, sendo resultado de um acúmulo de libido (energia sexual psíquica) 'solta', desligada, pelo recalque, de suas representações. Este excesso de libido acumulada irromperia, então, sob a forma de angústia. Portanto, neste momento da teoria freudiana, é o recalque que preside a irrupção da angústia, e não o contrário. A respeito da íntima ligação entre angústia e libido, Freud diz o seguinte em uma nota de rodapé, acrescentada em 1920, em seus "Três ensaios sobre a teoria da sexualidade":

Um dos resultados mais importantes da pesquisa psicanalítica é essa descoberta de que a angústia neurótica se origina da libido, que é produto de uma transformação desta e que, assim, se relaciona com ela da mesma forma que o vinagre com o vinho. (Freud, 1905, p. 231)

Estas primeiras concepções freudianas, privilegiando os aspectos orgânico e energético do fenômeno da angústia, nos permite efetuar aqui uma comparação destas com o funcionamento de uma usina hidrelétrica. A ideia do transbordamento de um excesso de energia sexual somática ou psíquica, que não foi devidamente escoado, poderia ser equiparada à imagem da água que transborda de uma represa, em períodos de muita chuva - com a consequente cheia dos rios - inundando casas, pastos e plantações, causando, invariavelmente, sérios prejuízos. 


\subsection{A virada de 26}

Posteriormente, em 1926, quando publica 'Inibições, Sintomas e Angústia', Freud passa a defender a ideia da angústia como uma forma de reação a uma situação de perigo, ou traumática, desviando, assim, sua atenção da transposição direta da libido em angústia. Diz Freud:

Nossa hipótese anterior de uma transformação direta da libido em angústia possui menos interesse para nós agora do que antes. (Freud, 1926[1925]/1996, p. 158)

Freud, porém, não chega a abandonar completamente suas proposições anteriores, continuando a sustentar o papel do excedente de libido não utilizada na etiologia da angústia.

A angústia passa a ser pensada, portanto, como uma resposta psíquica e corporal diante de uma experiência de desamparo. Esta vivência de desamparo resulta de experiências do cuidado do adulto, já que o que Freud vai dizer é que a ausência da mãe provoca angústia, a perda de sua presença, independente de se a criança está precisando dela para resolver um acúmulo de excitação ou não. Primeiro a perda da percepção da mãe (ela sumiu), em seguida a perda do seu amor. É por esse motivo que Freud dirá em seu 'Projeto' que o desamparo infantil está na origem de todos os motivos morais (1950[1895]/1996, p. 370). Ou seja, o poder do supereu é diretamente proporcional à vulnerabilidade infantil. $\mathrm{O}$ problema é que este mesmo supereu é desde sempre paradoxal: ao mesmo tempo em que protege, ameaça de invasão; esta é a ideia contida na metáfora lacaniana do jacaré de boca aberta. Resultado: angústia. Che vuoi? O que quer esse Outro de mim?

Então já é algo que não está no plano meramente econômico, de acúmulos e excessos, mas que começa a passar para o campo das representações psíquicas do desejo, da perda e da castração. É exatamente a impossibilidade de representação, a incapacidade de verbalização e simbolização frente a situações traumáticas de perda e separação, que ocasionariam os sintomas corporais observados na angústia. Sobre esta vivência de desamparo, Rudge (2009) afirma o que segue: 
O infante nasce sem recursos para se prover e sobreviver, é extremamente dependente do adulto que cuida dele. A importância assumida pelo adulto, por serem seus cuidados indispensáveis para que a criança não sofra e não morra, é o solo sobre o qual se instaura a vivência de desamparo e de angústia a cada vez que a mãe se afasta. (Rudge, 2009, p. 58)

Uma vivência traumática pode suceder situações de perigo e, principalmente, as de perda. Freud sustenta que a angústia seria uma reação-sinal, uma defesa, ante a perda de um objeto: perda da mãe, perda do amor do objeto, perda do amor do supereu (que vem a representar os adultos que cuidaram da criança) e, acima de tudo, perda do pênis, ou castração. Nesta etapa de construção da sua teoria da angústia, Freud passa a associar a ideia de angústia à angústia de castração, que poria em movimento o recalque, admitindo, assim, que é a angústia que causaria o recalque e não o contrário. Diz Freud:

É sempre a atitude de angústia do ego que é a coisa primária e que põe em movimento o recalque. A angústia jamais surge da libido reprimida. (Freud, 1926[1925]/1996, p. 111)

Assim, Freud parece abandonar de vez sua proposição de transformação direta da libido em angústia, o que não é bem verdade, pois continua afirmando, no mesmo texto de 1926:

Talvez ainda seja verdade, portanto, que no recalque a angústia é produzida a partir da catexia libidinal dos impulsos instintuais. Mas como podemos reconciliar essa conclusão com nossa outra conclusão de que a angústia sentida em fobias é uma angústia do ego e que surge neste, e de que não parte do recalque mas, ao contrário, põe o recalque em movimento? Parece haver aqui uma contradição que de modo algum constitui um assunto simples de solucionar. Não será fácil reduzir as duas fontes de angústia a uma única. (Freud, 1926[1925]/1996, p. 112)

Freud estabelece, ainda, uma distinção entre aquilo que chamou de 'angústia automática' e 'angústia como sinal'. Quando a angústia surge como resultado direto de uma situação traumática, de desamparo, resultante de um afluxo de excitações, tanto de origem interna como externa, com que o sujeito é incapaz de lidar, foi chamada por Freud de 'angústia automática'. Enquanto que a 'angústia como sinal' surgiria quando a angústia é reproduzida pelo eu como um 
alerta frente a uma provável situação de perigo, que poderia resultar em um aniquilamento do próprio eu. Na pena do mestre:

Ele (o eu) vividamente imagina a situação de perigo, por assim dizer, com a finalidade inegável de restringir aquela experiência aflitiva a uma mera indicação, a um sinal. (Freud, 1926[1925]/1996, p. 158).

Desta forma, podemos dizer que a 'angústia automática' estaria relacionada à primeira experiência de angústia/desamparo vivida pelo sujeito, enquanto que a 'angústia como sinal' adviria a partir de situações que reativassem as marcas deixadas por esta primeira experiência traumática. Entretanto, em certas circunstâncias, a 'angústia traumática' pode se estabelecer automaticamente a qualquer fase da vida.

Outra distinção presente na teoria freudiana da angústia, diz respeito à fonte da excitação causadora de angústia, que pode ser tanto exógena (causa externa) quanto endógena (causa interna). A angústia em sua etiologia externa, pode ser relacionada ao que Freud chamou de 'angústia ante um perigo real' ('Realangst'), enquanto que em sua vertente endógena seria causada por uma ameaça pulsional.

Freud vai indicar ainda que a sujeição permanente ao afeto de angústia seria o que viria a caracterizar um quadro de neurose ou histeria de angústia. $\mathrm{O}$ primeiro seria, como vimos, o que Freud chamou de neurose atual, e o segundo de psiconeurose. Cabe ressaltar que para Freud (e Lacan), a angústia nunca é neurose, é sempre afeto, que pode vir, em sua insistência ou falta de cabimento do que a motiva, como nas fobias, a caracterizar uma neurose. Nas palavras de Freud temos o seguinte:

A psique é invadida pelo afeto de angústia quando se sente incapaz de lidar, por meio de uma reação apropriada, com uma tarefa (um perigo) vinda de fora; e fica presa de uma neurose de angústia quando se percebe incapaz de equilibrar a excitação (sexual) vinda de dentro. (Freud, 1895[1894]/1996, p. 112)

A angústia, portanto, é um afeto que não caracteriza, em princípio, qualquer patologia e faz parte da nossa "psicopatologia da vida cotidiana". Enquanto que, em sua apresentação como neurose, estaria vinculada à incapacidade do aparelho 
psíquico em lidar com uma excitação endógena, análoga à exógena, porém com o inconveniente da sua constância, da força constante da pulsão, chamada por Freud de "konstant-kraft".

Como podemos perceber, há uma multiplicidade de ideias e tentativas de conceituação da angústia na obra de Freud. Proposições estas muitas vezes contraditórias. Ele mesmo, Freud, faz esta constatação e afirma que nenhum de seus pontos de vista poderia sobressair-se sobre os outros. Senão vejamos:

Até agora a nada chegamos, a não ser a pontos de vista contraditórios sobre ela (a angústia), nenhum dos quais pode, diante de uma opinião destituída de preconceito, ter preferência sobre os outros. (Freud, 1926[1925]/1996, p. 131)

Consideramos, assim, as teorias freudianas sobre a angústia não como sendo excludentes, mas complementares, uma vez que podem ser compreendidas como etapas diferentes da concepção, pelo gênio inventor da psicanálise, de um mesmo e complexo fenômeno: o fenômeno de produção da angústia.

\subsection{Meio-termo entre gozo e desejo}

A angústia, portanto, é um termo intermediário entre o gozo e o desejo, uma vez que é depois de superada a angústia, e fundamentado no tempo da angústia, que o desejo se constitui. (Lacan, 1962-63/2005, p. 193)

Situada, por Lacan, neste lugar especial - representado pelo meio-termo entre gozo e desejo - a angústia passa a ser vista como termo intermediário, apontando, na clínica, para o direcionamento da cura do sujeito. Para ilustrar a importância desta proposição lacaniana, 'A angústia entre o gozo e o desejo' foi o título escolhido para nomear o terceiro capítulo do seu seminário 10 - 'a angústia'.

A angústia, compreendida como este intervalo que marca a passagem do gozo ao desejo, passa a representar, com efeito, o exato momento do salto no qual o sujeito se arrisca, sem garantia alguma, sem anteparo algum de proteção (a não 
ser a palavra), no caminho desde o gozo até o desejo. Caminho este, vale ressaltar, fundamentalmente marcado pela perda, mais precisamente, pela perda de gozo. A angústia passa a ser vista, desta maneira, como uma bússola indicando o percurso do sujeito, desde o gozo até o desejo.

Utilizando-se de um esquema gráfico (Figura 6) que construiu com a finalidade de articular os conceitos freudianos de "inibição, sintoma e angústia", Lacan vai situar a angústia no pólo extremo deste seu esquema, que corresponderia, ao mesmo tempo, ao máximo de movimento/perturbação/efusão ('émoi') e ao máximo de dificuldade/embaraço ('embarras'). Tanto movimento e dificuldade - nos remete à ideia de 'queda livre', frequentemente associada ao conceito de angústia; quando não há onde se agarrar.

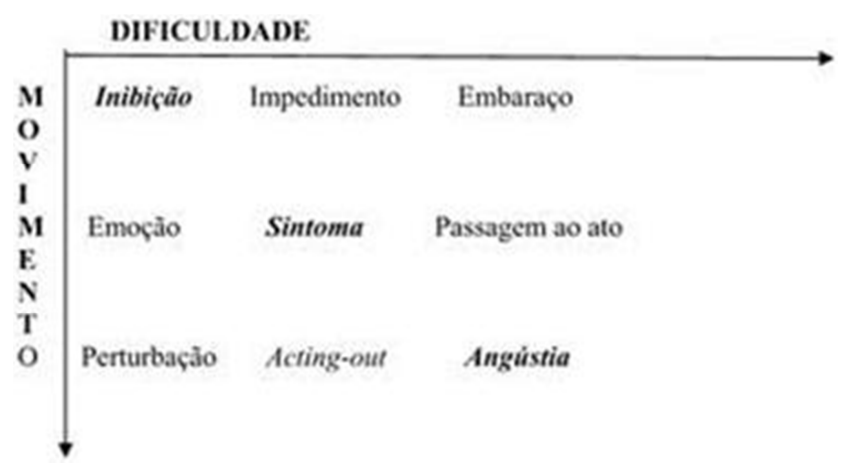

Figura 6 - Quadro da angústia

Desta maneira, ficam representadas no quadro as três formas primordiais de defesa, à disposição do sujeito, para enfrentar a angústia: sintoma, passagem ao ato e acting out. O sintoma, compreendido como formação de compromisso entre forças conflitantes, carrega consigo uma mensagem cifrada, um gozo velado, passível de decifração na transferência. O acting-out, por sua vez, diz respeito a uma determinada atuação do sujeito, em uma 'cena', que teria como propósito mostrar algo ao Outro. Uma mostra-ação. A passagem ao ato, recurso mais radical dos três para lidar com a angústia, representa o momento no qual o sujeito, diante de um ponto insuportável de angústia, pula fora da cena. Diz Lacan: "Esse 
largar de mão ('laisser tomber') é o correlato essencial da passagem ao ato" (Lacan, 1962-63, 2005, p. 129).

Lacan, acompanhando Freud, vai caracterizar a angústia como um 'afeto', notadamente, o único afeto acima de qualquer suspeita, aquele que não engana (1962-63/2005, p. 88). Apoiando sua ideia no fato de que o afeto não é recalcado, Lacan (1962-63/2005, p. 23) explica que o afeto se desprende dos significantes que o amarram, ficando à deriva e podendo ser encontrado deslocado, enlouquecido, invertido, metabolizado, mas nunca recalcado.

Fiel à letra de Freud, Lacan também vai argumentar que a fonte da angústia não é sempre interna ao sujeito, sendo frequentemente de origem externa, vinda a partir do outro, de nossos semelhantes, do mesmo modo como é transmitida de um animal a outro na horda. Falando desta angústia de origem externa, Lacan, num raro momento de referência à biologia, diz o seguinte:

O sinal como reação a um perigo num complexo social, no nível biológico, é portanto apreensível numa sociedade observável. Pois bem, o mesmo acontece com o sinal de angústia. (Lacan, 1960-61/1992, p. 352)

É por isso que o analista não deve permitir que sua própria angústia interfira na análise, um requerimento que ele somente é capaz de atender porque ele mantém um desejo próprio da sua função, qual seja, o desejo do analista.

Antes de prosseguirmos com o olhar do psicanalista francês Jacques Lacan sobre a angústia, há que se marcar uma distinção breve, mas importante, entre os conceitos psicanalíticos de angústia e fobia. Distinção esta que irá nos auxiliar na compreensão da visão lacaniana da angústia.

\subsection{Angústia, fetiche e fobia}

Lacan argumenta que a angústia é o perigo radical que o sujeito busca evitar a todo custo, e que as diferentes formações sintomáticas encontradas na psicanálise, de fobias ao fetichismo, seriam formas de proteção contra a angústia. A angústia estaria presente, portanto, em todas as estruturas neuróticas, sendo 
especialmente evidente na fobia. Tanto a fobia como o fetiche seriam espécies de escudo contra a angústia, sendo preferível ao sujeito, se houvesse opção, sofrer de fobia a sofrer de angústia. Lacan indica, de forma bem direta, que existe aquele objeto que é capaz de localizar sua angústia, este é, precisamente, o objeto da sua fobia (Lacan, 1962-63/2005, p.93).

De acordo com Coelho dos Santos e Zeitoune (2011), a função da fobia é "substituir o objeto radicalmente inconsciente da angústia por um significante que provoque medo". Medo ao invés de angústia. Na visão das autoras, portanto, o objeto fóbico seria menos inquietante do que o desejo do Outro, cuja presença é sinalizada pela angústia. Articulando medo e angústia, Vieira (2008) vai caracterizar a angústia como um medo sem razão, quando "aparentemente nada de anormal acontece para justificar". O autor diz aparentemente, pois, em suas próprias palavras, não devemos tomar "o indefinido por inexistente e o invisível por vazio".

O fetiche, por sua vez, outro eficaz recurso de defesa contra a angústia, funciona basicamente como uma espécie de véu de proteção, cuja função seria exatamente a de encobrir o terrível e perturbador buraco da angústia. Para exemplificar, tanto a calcinha quanto o pé, dois clássicos objetos-fetiche masculinos, teriam uma mesma e importante função, qual seja, a de proteger (velar) o sujeito da visão ameaçadora e angustiante da castração, presentificada no órgão genital feminino. Lacan (1956-57/1995) diz o seguinte:

o fetiche desempenha, na teoria analítica, uma função de proteção contra a angústia e, coisa curiosa, a mesma angústia, isto é, a angústia de castração. (Lacan, 195657/1995, p. 22).

Voltando à fobia, em sua articulação com a angústia, Miller (2007, p. 33) afirma de forma bem direta: "Es la fobia que desangustia". Freud sempre caracterizou a angústia pela fobia, porém, na fobia ela (a angústia) não está difusa, mas fica atrelada a um objeto específico e, portanto, passível de ser nomeado, falado, articulado, o que traz certo alívio. A angústia, por sua vez, é terrível para o sujeito na medida em que não é causada, nem direcionada a nenhum objeto específico, como na fobia, mas gira em torno de uma ausência, de um vazio, de 
uma impossibilidade de dizer. Vieira (2008) aborda da seguinte maneira esse vazio diante do qual nos angustiamos:

aquilo diante do que nos angustiamos é estranhamente vazio. (...). A angústia, por outro lado, seria um medo sem razão, sem objeto, já que sua situação mais típica é aquela em que aparentemente nada de anormal acontece para justificar. (Vieira, 2008, p. 30)

Em sua análise do caso do 'Pequeno Hans' (Freud, 1909), Lacan argumenta que o menino poderia ter sido salvo de sua angústia, e da consequente fobia, pela intervenção castradora do pai real, mas isto não aconteceu. Na visão de Lacan, o pai falha em sua função primordial de separar Hans de sua mãe, e, a partir daí, o menino desenvolve a angústia e, posteriormente, a fobia, em substituição a esta intervenção que não houve. $\mathrm{O}$ que salta aos olhos nesta leitura lacaniana do Pequeno Hans, é o fato de que não é a separação da mãe que causa angústia no garoto, mas sim a falta desta separação. Consequentemente, a castração, longe de ser a principal causa da angústia, como pensava Freud, é, na verdade, aquilo que salva o sujeito da angústia. Lacan (1956-57/1995) aborda da seguinte maneira aquilo que chamou de "fundamento da angústia":

Trata-se de que o pequeno Hans encontre uma suplência para este pai que se obstina em não querer castrá-lo. Esta é a chave da observação. Trata-se de saber como o pequeno Hans vai poder suportar seu pênis real, justamente na medida em que este não é ameaçado. Aí está o fundamento da angústia. (Lacan, 1956-57/1995, p. 375)

Sobre o papel secundário da fobia, em sua função de proteção contra a angústia, Lacan (1956-57/1995) esclarece o seguinte:

A aparição do cavalo é secundária. Ela acompanha a angústia. Freud o sublinha, é pouco tempo depois da aparição do sinal difuso da angústia que o cavalo entra em funcionamento. (Lacan, 1956-57/1995, p. 314)

A angústia de Hans que, em sua origem, não tinha relação alguma com os cavalos, e revolvia em torno de um vazio - do vazio deixado pelo pai - busca, em um momento seguinte, seu suporte na fobia, no medo diante de um objeto, 
representado pelo cavalo. Hans pode, enfim, 'ter uma angústia diante de alguma coisa' (Lacan, 1956-57/1995, p. 355).

\subsection{Além da angústia de castração}

Lacan, em seu retorno a Freud, procura ir 'além da angústia de castração'. No início de seu ensino, começa por relacionar a angústia com a ameaça de fragmentação do corpo (corps morcelé), com a qual o sujeito é confrontado no estádio do espelho, e que estaria relacionada com a ameaça de castração, assim como proposto por Freud. Até mesmo na experiência reconfortante de ver nossa imagem no espelho, poderia ocorrer um momento em que a imagem especular pareça modificada e, de repente, nos pareça estranha. Desta forma, Lacan estabelece uma ligação entre os conceitos de angústia e estranho ('unheimlich') em Freud. Ao mesmo tempo em que nos apresenta a angústia diante da falta, da perda, da ausência, ou seja, da castração, Freud também fala do surgimento da angústia diante da falta de falta, ou seja, frente à presença de algo (coisas, pessoas, impressões, eventos e situações) assustador que é, simultaneamente, estranho e há muito familiar. Diz ele que o tema do estranho "relaciona-se indubitavelmente com o que é assustador - com o que provoca medo e horror." (Freud, 1919/1996, p. 237).

Demonstrando, de maneira sucinta e esclarecedora, as inter-relações existentes entre três conceitos fundamentais da psicanálise, a saber, angústia, estranho e fantasia, Rudge (2005) vai dizer o seguinte:

O breve momento em que a fantasia se desfaz, momento do estranho, é um momento de angústia porque provoca a oscilação das referências em que o sujeito costuma se apoiar. (Rudge, 2005, p. 86)

Lacan vai relacionar a angústia com a ameaça experimentada pela criança de ser engolida pela mãe devoradora (bocarra do jacaré), marcando assim uma diferença entre a sua visão e a proposta freudiana, na qual uma das causas da angústia seria, pelo contrário, a separação/ausência da mãe. Lacan vai propor que 
é precisamente a falta desta separação, a falta desta ausência que provocaria angústia.

Em seu Seminário 10 (a angústia), Lacan passa a articular a angústia com o conceito de falta. Segundo ele, todo desejo advém da falta, e a angústia surgiria exatamente quando esta falta está faltando ('le manque vient à manquer'). Uma das definições lacanianas de angústia seria, portanto, o que ele chamou de 'falta de falta'. Pode-se dizer que a falta está para o desejo, assim como a falta de falta está para a angústia.

Percebemos, portanto, uma diferença crucial em relação às propostas lacaniana e freudiana sobre o fenômeno da angústia: enquanto Freud enfatiza, como uma das causas da angústia, a separação da mãe, Lacan propõe que é exatamente a falta desta separação que ocasionaria angústia. A angústia, segundo Lacan, surgiria não em função da ausência do seio, mas, ao contrário, a partir de sua presença, massiva e sufocante. É justamente a possibilidade de sua ausência, ou seja, da ausência da mãe (e do seio que ela porta), o que de fato nos preveniria da angústia. A seguinte passagem do mestre francês deixa claro seu ponto de vista sobre o assunto:

\begin{abstract}
Vocês não sabem que não é a nostalgia do seio materno que gera a angústia, mas a iminência dele? O que provoca a angústia é tudo aquilo que nos anuncia, que nos permite entrever que voltaremos ao colo. (...) e ela (criança) fica perturbada ao máximo quando não há possibilidade de falta, quando a mãe está o tempo todo nas costas dela (...) (Lacan, 1962-63/2005, p. 64)
\end{abstract}

Na medida em que a mãe direciona seu olhar para outros objetos, além do seu filho, ela aponta para um desejo além deste, causando justamente o desejo da criança. Caso contrário, de acordo com Biaggio (2012), produz-se uma espécie de afogamento, ou seja, a asfixia do infante. Segundo a autora, algumas crianças sinalizam tal sufocamento com sintomas que remetem, por exemplo, à asma e demais problemas respiratórios, cujo tratamento frequentemente passa pela recomendação médica para que as crianças nadem. Sim, natação! Nadar para não se afogar no 'mar materno’! A propósito, 'mer', em francês, significa 'mar', sendo um termo homófono de 'mère' (mãe). 
Outra curiosa coincidência linguística, que serve bem para nos auxiliar na compreensão da visão lacaniana da angústia, é o significado da palavra inglesa 'smother' ou, com o auxílio dos parênteses, '(s)mother'. Vejamos o significado que aparece no Dicionário Oxford, para este curioso termo da língua inglesa que traz embutida a palavra 'mãe':

smother $\boldsymbol{v}$. [with obj.] kill (someone) by covering their nose and mouth so that they suffocate. - make (someone) feel trapped and oppressed by acting in an overly protective manner towards them. (...) ${ }^{16}$

Podemos estabelecer aqui uma ligação entre esta concepção lacaniana da angústia e o valor que Jones (1927) conferiu ao conceito de aphanisis como fonte mais fundamental da angústia e de toda neurose. Aphanisis é o termo utilizado na psicanálise para denotar o desaparecimento do desejo (sexual) e, consequentemente, o desvanecimento do próprio sujeito. Sua origem do grego aphanes - remete justamente à ideia de 'invisível'. De acordo com Rudge (2005), a concepção de aphanisis encontra um lugar privilegiado na teoria lacaniana da angústia, na medida em que, como vimos, a situação traumática é ser reduzido à posição de objeto pelo desejo/gozo do Outro. A ameaça de aphanisis na clínica pode ser traduzida por pensamentos de castração e morte (Jones, 1927, p. 460); "ameaça de morte psíquica, de apagamento do sujeito, e é isso que o incesto convoca (...) desejo moldado pelo desejo materno que esteve no início: o de reintegrar seu produto" (Rudge, 2005, p. 87).

A angústia, como vimos, é um afeto, notadamente, o único afeto que não engana. É causada não pela falta, mas sim pela falta de falta. Ou seja, é quando um mecanismo faz surgir alguma coisa no lugar da falta que a angústia se instala, uma vez que a falta (condição do desejo) falta. Quando algo surge no lugar da castração, é isso que provocaria angústia. Consequentemente, a castração, longe de ser a principal causa da angústia, como acreditava Freud, seria de fato aquilo que salvaria o sujeito da angústia. Aquilo que poderia ter salvo Hans dos caprichos maternos, e da consequente angústia, ancorada posteriormente na sua fobia. Vejamos como Braunstein (2007) conduz a questão:

\footnotetext{
${ }^{16}$ matar (alguém), cobrindo-lhe o nariz e a boca, de modo que a pessoa sufoque. - fazer (alguém) se sentir preso e oprimido, agindo de maneira excessivamente protetora em relação a esta pessoa.
} 
É sabido que para Lacan, diferentemente de Freud, a castração não é uma ameaça, mas, pelo contrário, é salvadora. A ameaça verdadeira, a terrível, é que não haja castração. A clínica mostra, às vezes, que os defeitos na função do pai, que é a de incluir o sujeito na ordem simbólica, é a causa de um apelo desesperado, patético, à intervenção castradora que separe a criança do gozo e do desejo da mãe. (Braunstein, 2007, p. 46)

Uma analogia interessante, que serve para bem ilustrar as graves consequências da 'falta de falta' - 'falta de falta d'água', neste exemplo - surgiu a partir de uma despretensiosa conversa com uma paisagista, especialista em botânica, na qual fui informado de que é mais fácil uma planta morrer pelo excesso do que pela falta d’água. Interessante...

\subsection{Angústia e desejo do Outro}

achei que devia, à guisa de parêntese em meu discurso do ano passado, projetar de antemão uma formulação que thes indicasse a relação essencial da angústia com o desejo do Outro. (Lacan, 1962-63/2005, p. 13-14)

A fábula do 'louva-a-deus gigante', utilizada por Lacan no início do Seminário 10: a angústia (1962-63/2005, p. 14), nos fornece uma boa dimensão do que se trata na angústia diante de um Outro, que se apresenta, ao mesmo tempo, como enigmático e assustador, e de quem eu não tenho a menor ideia do que quer e, principalmente, do que quer de mim, propondo assim o enigma Che vuoi? O sujeito se angustia na medida em que não sabe que objeto representa para o desejo do Outro. Que queres? O que queres de mim?

Esta fábula conta a estória de um personagem mascarado que se vê diante de um inseto de aparência assustadora, um louva-a-deus gigante, e que por não saber que máscara está usando, não sabe se este louva-a-deus iria encontrar nele o objeto do seu desejo ou não, se iria devorá-lo ou não. Cabe esclarecer que as fêmeas dessa espécie de inseto têm o hábito de arrancar a cabeça do parceiro e 
comê-lo, logo após o ato sexual. A angústia estaria ancorada, portanto, no desejo do Outro, uma vez que não temos como saber que objeto somos em relação a este desejo; só imaginariamente podemos supor nossa posição no desejo parental e aí construímos nossa fantasia.

Ao referir-se ao desejo do Outro, Lacan traz a dimensão do Outro como lugar do significante para a definição da angústia. Aquilo que o Outro quer, mesmo que não saiba o que seja, é necessariamente minha angústia. Ao comentar isto que chamou de 'nova faceta da angústia', Rudge (2009) aborda a questão da seguinte maneira:

Jones e Lacan trouxeram à luz uma nova faceta da angústia, mostrando que a morte psíquica é uma ameaça vinculada não apenas à perda do Outro ou de seu amor, mas também, paradoxalmente, à presença de seu desejo, já que este desejo ameaça reduzir o sujeito à posição de mero objeto. (Rudge, 2009, p. 58)

É neste ponto que Lacan recorre ao livro de Jones sobre os pesadelos (1971), afirmando que "a angústia do pesadelo é experimentada, propriamente falando, como a do gozo do Outro. O correlato do pesadelo é o incubo ou o súcubo, esse ser que nos comprime o peito com todo o seu peso opaco de gozo alheio, que nos esmaga sob seu gozo" (Lacan, 1997, p. 73).

A partir de sua relação com o Outro, o sujeito (barrado) se inscreverá como um quociente, isto é, como um resultado dessa marca significante. Da operação de divisão produz-se um resto, um resíduo, um excedente. Esse resto, esse irracional, esse enigma, é o objeto $a$, única garantia da alteridade do Outro. Objeto este que Lacan elevou à condição de 'causa de desejo', e, ao mesmo tempo, 'objeto da angústia'. A problemática da angústia, portanto, se vincula ao desejo do Outro justamente enquanto estrutura portadora desse enigma - a angústia surge quando o sujeito é confrontado pelo desejo do Outro e não tem a menor ideia de que objeto ele é em relação a este desejo. Che vuoi?

Nos angustiamos, portanto, sempre diante de algo. Não diante de uma ausência, mas primordialmente, diante da presença de algo do registro do real, algo que pode ser definido também como presença de uma ausência. Vieira (2008, p. 29) vai chamar esta presença 'anterior a tudo o que podemos elaborar ou 
compreender', presença diante da qual nos angustiamos, de 'presença do Outro'. Para ilustrar essa tal presença angustiante, o autor descreve uma cena na qual Maicom, um jovem de 19 anos, resolve atender um orelhão que está tocando, em frente a um supermercado, no período em que traficantes aterrorizavam a cidade do Rio de Janeiro com ameaças e violentos atos de terror. Ao atender a ligação, Maicom ouve uma voz que lhe pergunta se o comércio à sua volta está fechado. Diante da resposta negativa do rapaz, a voz lhe ordena que 'desça e feche tudo'. Maicom pergunta quem está falando, e a voz responde apenas que estava lhe vendo de longe e que era para ele obedecer. 'Apenas tive a infelicidade de estar na hora errada, no local errado e agora estou nesta situação', afirmou Maicom. Está aí ilustrada esta angustiante 'presença do Outro', necessariamente, fruto de uma relação.

\subsection{Objeto da angústia}

Aquilo diante do que nos angustiamos é estranhamente vazio. (Vieira, 2008, p. 30)

Para Lacan, a angústia não é sem objeto (' $n$ 'est pas sans objet'), o que não significa dizer que ela tenha um objeto. $\mathrm{O}$ objeto de que se trata na angústia é um tipo diferente de objeto, um tipo especial, um objeto que escapa à simbolização, que não pode ser simbolizado da mesma maneira que os demais objetos. Este objeto absolutamente singular, quase imperceptível, que, de fato, é apenas um lugar, um vazio, e que também ostenta a função especial de causa do desejo, foi nomeado por Lacan de 'objeto pequeno $a$ ', ou simplesmente, 'objeto $a$ '. Se repararmos no desenho do a minúsculo, percebemos que esta letra, além de representar o 'pequeno outro' ('autre'), também representa graficamente um lugar vazio, um espaço delimitado senão por um traço, uma borda. A semelhança do objeto a com o algarismo zero (0) é também inevitável. Sobre este vazio da angústia Badiou (1994, p. 96) diz o seguinte "a angústia, que é um excesso de real, é a experiência crucial do zero, ou do vazio". 
O objeto $a$, objeto da angústia por excelência, pode ser percebido também como um objeto da ordem do traumático, que escapa a qualquer tentativa de simbolização, e diante do qual não há mediação possível. Sobre o objeto da angústia, Lacan (1962-63/2005, p. 87) vai dizer que "é por isso que constitui um erro dizer que a angústia é sem objeto. A angústia tem um tipo de objeto diferente".

Lacan dedicou especial atenção ao desenvolvimento do conceito de objeto $a$, dando-lhe consistência teórica, por tratar-se de um termo intermediário, um objeto que faria uma espécie de mediação entre gozo e desejo - "um amboceptor entre desejo e gozo" (Miller, 2011, p. 195). Não por acaso, trata-se do mesmo local onde Lacan situa a própria angústia. Portanto, o objeto a, causa do desejo, como vimos, também é apresentado por Lacan como objeto da angústia, justamente por exercer esta função mediadora entre gozo e desejo. A angústia surgiria, com efeito, quando algo aparece no lugar representado por este objetofuro especial. Ou seja, quando a falta, falta, ou, como indica Miller (2007, p. 94), quando há objeto e quando há muitos objetos.

\subsection{Da angústia ao desejo (e vice-versa)}

Articulando desejo e angústia, Lacan, ao final do seu Seminário 8, afirma que, para a angústia se constituir, é preciso que haja uma implicação do desejo. Em suas palavras:

o sinal de angústia tem uma ligação absolutamente necessária com o objeto do desejo. Sua função não se esgota na advertência de ter que fugir. Ao mesmo tempo em que realiza esta função, o sinal mantém a relação com o objeto de desejo. (Lacan, 1960-61/1992, p. 352)

A angústia, portanto, seria uma forma, uma possibilidade de sustentação do desejo, quando a falta, falta. Paradoxalmente, a angústia é também tomada por 
Lacan como uma última barreira de sustentação do desejo. Segundo Lacan (196061/1992):

Quando atingimos este ponto, a angústia é o último modo, modo radical, sob o qual o sujeito continua a sustentar, mesmo que de uma maneira insustentável, a relação com o desejo. (Lacan, 1960-61/1992, p. 353)

Lacan nos apresenta, por outro viés, a articulação entre a angústia e o desejo, ilustrando a ideia da constituição do desejo pelo ultrapassamento da angústia. Em outras palavras, é preciso superar a dor da castração/separação da mãe para que possamos nos constituir enquanto seres desejantes, e, ao mesmo tempo, seres capazes de gozar, não da mãe, mas da vida.

Partindo da teoria freudiana dos sonhos como realização fantasmática de um desejo recalcado, Rudge (2005) apresenta com as seguintes palavras, sua importante contribuição às possibilidades de entrelaçamento entre desejo e angústia. A angústia, que advém da falha da distorção do desejo no sonho, mostra que o sinal de angústia, o que ele sinaliza é o retorno do desejo recalcado:

quanto mais intenso for o conflito, mais a realização onírica do desejo tende a se apresentar de forma distorcida (...). Entretanto, não é sempre que o trabalho de censura ou cifração obtém sucesso. Quando o desejo é especialmente intenso, pode driblar a censura. Nesse caso, a relação entre a distorção e a angústia será inversa. Quanto mais o desejo escapou à distorção, maior a manifestação da angústia que o acompanhará. (Rudge, 2005, p. 83)

A angústia sinal sinaliza um perigo, perigo que Jones (1927) considera ser provocado pelo que chamou de "buried desire" ("desejo enterrado"). O temível retorno deste desejo a partir das profundezas da psique é sinalizado com a angústia. Assim como em Freud, o que o sinal de angústia sinaliza é o retorno do recalcado, ou seja, o desejo do Outro como desejo inconsciente (Rudge, 2005, p. $85)$.

$\mathrm{O}$ amor, segundo Lacan, funcionaria como antídoto para a angústia. A via do amor é vista por Lacan como oposta à via da angústia. Enquanto a angústia conduziria o sujeito ao objeto real, ao objeto de satisfação da pulsão - satisfação esta que é gozo - o amor é apresentado como via de acesso ao objeto simbólico, 
mais precisamente, ao falo, enquanto símbolo do desejo da mãe, ao desejo como desejo do Outro.

Na via do amor, segundo Miller (2007, p. 70), o objeto real seria elevado à dignidade do objeto simbólico, passando-se "de la satisfacción estúpida de la

necesidad a lo indefinido del deseo metonímico ${ }^{17}$ ". Desta maneira, Miller parece ter esclarecido e recolocado o famoso aforismo lacaniano: "Só o amor permite ao gozo condescender ao desejo" (Lacan, 1962-63/2005, p. 197). É o amor visto como uma espécie de véu que recobre a angústia e aquilo que ela produz, que seria, como vimos, o objeto $a$.

\subsection{Gozo e angústia}

Gozar sob ordens, afinal, é algo sobre o qual todo o mundo sente que, se existe uma fonte, uma origem da angústia, ela deve estar mesmo em algum lugar por aí. (Lacan, 1962$63 / 2005$, p. 91)

Podemos começar a abordar as relações existentes entre os conceitos de gozo e angústia pela frase escolhida para iniciar esta parte do trabalho. Nesta passagem esclarecedora, Lacan indica o imperativo do gozo (Goza!), mandamento do supereu, como fonte da angústia. Angústia diante de uma presença; da presença de um mandamento, de uma ordem para gozar advinda de uma instância superior, de uma obrigação da qual o sujeito não consegue escapar. Apesar de não haver concebido o gozo, tal como o fez Lacan, Freud, sem dúvida preparou o terreno para o mestre francês. As seguintes passagens do pai da psicanálise nos ajudam a entender a dinâmica por trás desse imperativo do gozo lacaniano: "Ele (o eu) não é apenas um auxiliar do isso; é também um escravo submisso que corteja o amor de seu senhor (supereu)" (Freud, 1923/1996, p.68); "Ele (o supereu) constitui uma lembrança da antiga fraqueza e dependência do eu, e o eu maduro permanece sujeito à sua dominação.” (Freud, 1923/1996, p.61).

\footnotetext{
${ }^{17}$ Da satisfação estúpida da necessidade ao indefinido do desejo metonímico.
} 
Quando o sujeito se vê diante desta presença, massiva e sufocante, de um supereu tirano, que o obriga a gozar, exatamente aí advirá sua angústia. Qualquer semelhança com a presença igualmente 'massiva e sufocante' do seio materno, que oferece o leite à criança sem ao menos saber se é realmente isso que ela quer, não é mera coincidência.

Parecendo retornar à primeira teoria freudiana da angústia - angústia como libido transformada - Lacan, em seu seminário R.S.I (1974-75), ao tentar responder sua própria pergunta sobre o que seria angústia, diz o seguinte:

What is anxiety? It is what, at the interior of the body, ex-sists when something awakens it, torments it. 18 (Lacan, 1974-75; p. xviii)

Do que Lacan estaria falando, senão do gozo fálico que 'desperta e atormenta' o corpo? O próprio gozo sexual serve para bem ilustrar esta relação entre gozo e angústia, apontada por Lacan, na medida em que o êxtase sexual também 'desperta e atormenta' o corpo, produzindo neste, espasmos e contrações incontroláveis, que também poderiam ser classificadas de angustiantes, caso não cessassem logo em seguida. Fica estabelecida assim mais uma possível articulação entre os conceitos de angústia e gozo, presente na obra lacaniana.

Articulando gozo e angústia, Miller (2007, p. 93) escreve que o gozo passa pela angústia para chegar ao desejo. Ou seja, o que o autor propõe é que no caminho desde o gozo até o desejo há que se passar pela angústia. Angústia causada, antes de mais nada, por uma perda: a perda de gozo, mais especificamente, castração. Partindo desta ideia, pode-se dizer que a angústia visaria, portanto, recuperar esse gozo perdido no processo de castração simbólica, uma vez que foi exatamente esta perda que a causou. Assim, chegamos ao ponto de poder dizer que o gozo seria algo visado pelo sujeito quando este está tomado pela angústia. Gozo como forma de proteção contra a angústia. Tomemos o exemplo do 'Fort-da', famoso jogo-recurso utilizado pelo pequeno neto de Freud para lidar com a angústia, causada pela presença-ausência da mãe. $O$ garoto se entrega ao ritual, repetido várias vezes, de jogar e depois puxar o carretel de linha,

\footnotetext{
${ }^{18} \mathrm{O}$ que é angústia? É aquilo que, no interior do corpo, ex-siste quando alguma coisa o desperta, o atormenta.
} 
acompanhando tais movimentos com as quase-palavras "ôo" (Fort, longe) e "Da" (perto), numa espécie de jogo, que é, ao mesmo tempo, prazeroso e dolorido - uma 'jubilação mórbida', segundo Valas (2001). Ou seja, há gozo no 'Fort-da', da mesma maneira que há gozo no sintoma; e como sabemos, uma das funções precípuas do sintoma é a de proteger o sujeito da angústia.

Seguindo esta mesma linha e tomando todo o cuidado para não generalizar, uma vez que 'há usos e usos da droga', podemos inferir que o mesmo mecanismo por trás do inocente jogo do 'Fort-da' poderia estar presente também, por exemplo, em alguns casos de drogadição, como tentativa desesperada do sujeito de tamponar o vazio, o buraco, a falta angustiante de algo que é incapaz de nomear, passando 'de servo a senhor, de joguete a dono da bola' (Vieira, 2008, p. 90). A droga surge então como um recurso de que o sujeito pode lançar mão, mesmo que de maneira excessiva, para equilibrar-se e não o contrário, como o senso comum nos faz acreditar. Não custa frisar, que tal recurso não é absoluto e pode apresentar fragilidades. Tal é a tese defendida por Martins (2009), fundamentada pelo ensino de Lacan. Cito a autora:

\begin{abstract}
A relação entre droga e gozo apresenta um paradoxo: para alguns casos, o seu consumo opera liberando um gozo excessivo e, em outros, permite uma moderação do gozo. O segundo modo de operação da droga corresponde às tentativas de estabilização (...). (Martins, 2009, p. viii)
\end{abstract}

Eis a ideia do gozo que estabiliza. O gozo como antídoto para a angústia.

Ao situar o objeto $a$ - objeto da angústia - como um 'amboceptor entre desejo e gozo', Miller (2011, p. 195) fundamenta sua afirmação em duas proposições trazidas por Lacan ao longo de sua obra, que definem este objeto especial tanto como 'mais-gozar' como 'causa do desejo'. Neste momento, em que buscamos articular gozo e angústia, nos interessa a relação do objeto da angústia com o gozo, ou, mais precisamente, com o conceito lacaniano de 'maisgozar'. Em sua vertente 'mais-gozar', o objeto $a$ é tomado como inscrição na fantasia de um gozo que era absoluto; um resto/excedente de gozo produzido pela introdução do simbólico no real. O excesso de gozo passa a ser chamado de objeto $a$, como 'mais-gozar'. Tanto a angústia quanto o gozo situam-se num mais além e 
possuem a marca de um excesso, que é impossível de ser simbolizado. Articulando gozo e objeto $a$, Miller diz o seguinte:

(...) diante do real, o objeto $a$ é um artifício teórico. Eu dizia que funciona como uma unidade de gozo. (Miller, 2011, p. 196) 


\section{Do gozo}

\subsection{Sobre o gozo, uma introdução}

Chama-se o Gozo, e é aquele cuja falta tornaria vão o universo. (Lacan, 1966/1998, p. 834)

Em seu uso cotidiano, o termo gozo reveste-se, principalmente, de uma dimensão jurídica e outra sexual. No vocabulário jurídico remete à noção de usufruto, ou seja, ao direito de gozar de um bem, gozar de férias etc. No auge de seu vigésimo seminário, Lacan, ao começar a discorrer sobre o conceito de gozo, articula logo de saída a relação deste com o direito, mais especificamente, com o conceito jurídico de usufruto, ao dizer que "no fundo, o direito fala do que vou lhes falar - o gozo" (Lacan, 1972-73/1985, p. 10). A noção jurídica de usufruto diz respeito ao direito de uso de uma coisa alheia e ao gozo de seus frutos. A coisa objeto de usufruto continua pertencendo ao seu proprietário que, entretanto, quase não tirará proveito real dela, enquanto subsistir o usufruto. Esta conotação jurídica do termo gozo opõe claramente gozo e propriedade. Oposição esta que Sade (2008) reforça quando afirma:

Repito aqui tratar-se do gozo e não da propriedade; não tenho nenhum direito de propriedade sobre certa fonte que encontro em meu caminho, mas tenho todo o direito de usufruí-la, de desfrutar da água límpida que oferece à minha sede; também não tenho direito de propriedade desta ou daquela mulher, mas tenho incontestavelmente o de gozá-la. (Sade, 2008, p. 149)

Todavia, o proprietário mantém a expectativa de recuperar a plenitude sobre esse direito, que é alimentada justamente pelo caráter temporário do usufruto. A fim de se resguardar os interesses do proprietário, privado do uso e gozo de sua coisa durante a vigência do usufruto, este deve ser exercido dentro de certos limites, sem alterar a substância e zelando pela integridade e conservação da coisa alheia. A comparação com o conceito psicanalítico de gozo aqui é inevitável, na medida em que este, assim como o usufruto jurídico, para o bem do "sujeitoproprietário", também deve ser "exercido" dentro de certa regulação, que sirva 
para que o sujeito não dilapide seu patrimônio, seus bens, sua saúde, seu corpo. Adiantando uma das ideias discutidas ao longo do trabalho, esta seria, portanto, uma das possíveis barreiras ao gozo, qual seja o corpo, o corpo como limite. Caso contrário, no caso do direito, a relação jurídica poderá ser extinta pela destruição total da coisa concedida em usufruto - pois o direito não sobrevive sem seu objeto -, assim como o sujeito não sobrevive sem seu corpo. Por outro lado, percebemos, na seguinte passagem de André (1998), a oposição que se estabelece entre o gozo lacaniano e a noção jurídica de usufruto no tocante à questão da utilidade:

A noção de usufruto, por exemplo - que reúne o uso e o fruto - significa que se pode usar de um bem apenas até certo ponto: pode-se comer o produto, os juros, mas não o capital. O direito regulamenta assim o gozar limitando-o às fronteiras do útil. O gozo se define, ao contrário, como aquilo que se opõe ao útil: é, diz Lacan, aquilo que não serve para nada. (André, 1998, p. 211)

A propósito, esta polêmica assertiva lacaniana de que o gozo não serve para nada é claramente uma provocação do mestre francês, que sabe, melhor do que ninguém, o valor do gozo, a importância da satisfação pulsional para o equilíbrio psíquico do sujeito. A seguinte passagem de Miller (1988, p. 142) nos serve como bússola e evita nos enganarmos: "é verdade que o gozo é o mais substancial que há na experiência analítica". Sobre a importância do manejo do gozo no setting analítico, principalmente no que se refere ao seu aspecto estabilizador, ideia esta que nos é cara, discutiremos com mais detalhes no capítulo da clínica.

Em sua conotação sexual, gozo e gozar, tornam-se sinônimos de prazer, mais especificamente, da expressão máxima do prazer sexual. Não por acaso, Lacan escolheu o termo "gozo" (jouissance), palavra que possui conotação sexual, tanto em português quanto em francês, para designar o conceito psicanalítico que inventara. Para ilustrar a importância do caráter sexual do conceito lacaniano de gozo, o termo jouissance foi utilizado sem tradução na maioria das edições inglesas da obra de Lacan. Isto se deve ao fato de não haver no idioma inglês uma palavra capaz de expressar tal aspecto sexual do conceito de gozo, fortemente presente tanto no português (gozo), como no original francês (jouissance). A palavra inglesa que mais se aproxima do francês jouissance seria 'enjoyment', que transmite as ideias de usufruto/fruição/curtição - todas presentes no termo original 
jouissance - carecendo, porém, do seu aspecto sexual fundamental. Como curiosidade linguística, tanto o termo 'jouir', no francês, como gozar, no português, são termos que servem para exprimir o orgasmo (gozo sexual), enquanto que na língua inglesa utiliza-se a expressão 'to come', e não 'to enjoy. Como contribuição da psicanálise à língua inglesa, o termo jouissance passou a figurar no tradicional dicionário Oxford.

Segundo Lacan, o conceito de gozo, rico em nuances, nos remete à ideia de um excesso, de uma transgressão (da lei), de um "ir além dos limites" ou "além do princípio de prazer", como preferiu Freud ao intitular seu texto de 1920. Este trabalho de Freud é considerado um divisor de águas na teoria psicanalítica que, até então, considerava o "princípio de prazer" como princípio regulador do aparelho psíquico, o qual conduziria o indivíduo à busca pelo prazer e à evitação do desprazer. A partir da publicação deste trabalho, Freud reconhece que há algo para além do prazer, que seria exatamente aquilo que nomeou de pulsão de morte, tendo a compulsão à repetição como uma de suas principais expressões. Pode-se dizer que a pulsão de morte e a compulsão à repetição, bem como suas relações com o supereu, representam as principais bases teóricas referenciais na obra de Freud que serviram de matéria-prima para a construção do conceito de gozo por Lacan. O gozo, portanto, é aquilo que está para além do princípio de prazer, que é da ordem do excesso, da transgressão, e que, segundo Lacan, é causa de sofrimento - uma espécie de 'prazer dolorido'.

Fazendo coro à importância do tema em questão, tanto na teoria como na clínica, Rudge (2006), em seu artigo "Pulsão de morte como efeito de supereu", diz que a questão da constituição desta força que empurra o homem para a dor e para o sofrimento constitui o tema central na obra freudiana.

Pela irresistível atração pelo sofrimento que as caracteriza, essas manifestações clínicas foram o estopim para a maior reformulação da teoria freudiana, aquela que introduziu a segunda tópica e, no seio da nova teoria pulsional, a pulsão de morte, noção tão ambígua, controvertida e com frequência recusada, explicitamente ou não, por tantos psicanalistas. (Rudge, 2006, p. 79)

Percebemos assim uma estreita ligação da pulsão de morte com o supereu e a compulsão à repetição, e destas com o gozo. Conforme veremos a seguir, estas 
são as principais bases teóricas freudianas sobre as quais Lacan vai construir seu complexo conceito de gozo. De acordo com Rudge (2006), sem a ferramenta teórica do supereu, torna-se impossível o entendimento da operação e manejo da pulsão de morte na clínica psicanalítica. Acompanhemos a autora na esclarecedora passagem na qual deixa clara a importância dos conceitos de compulsão à repetição e pulsão de morte nos caminhos que levam para o sofrimento:

Sabemos que, ao invocar a compulsão à repetição e a pulsão de morte em 1920, Freud reconhecia e enfatizava a inexorabilidade da repetição nos caminhos que levam para o sofrimento, repetição que chegou a qualificar de demoníaca. (Rudge, 2006, p. 81)

Lembremos que, para Lacan, 'gozo é sofrimento', é 'prazer dolorido', estando situado, portanto, no mais além do princípio de prazer.

Ao se abrir mão do desejo, mais precisamente, do desejo incestuoso, ingressamos definitivamente no campo da lei e, portanto, do gozo. Abrir mão do desejo incestuoso significa que a lei se instaurou para o sujeito e, a partir daí, há o que se transgredir (a própria lei). Articulando gozo e transgressão, Miller (2012), em linha com a concepção do gozo a que chamou de "terceiro paradigma", aquele do "gozo impossível", "gozo real" ou ainda "gozo da Coisa", vai dizer o seguinte: "precisamos de uma terrível transgressão para alcançar o gozo" (2012, p. 19). Este é o paradigma que situa o gozo no terreno da transgressão, da traição responsável por sacudir a tradição, abrindo alas para a novidade. Com efeito, toda proibição faz surgir o desejo de transgressão, e o gozo é, sem dúvida, fundamentalmente transgressivo.

As diversas perspectivas do gozo presentes na obra de Lacan foram sistematizadas por Miller (2012) em seu famoso texto "Os seis paradigmas do gozo", que discutiremos no decorrer deste capítulo.

Em relação aos paradoxos, tão presentes no campo do gozo lacaniano, um dos mais intrigantes diz respeito ao fato de que negar o gozo, resistir a ele, ou se entregar a ele, segundo Vieira (2008), daria no mesmo para o sujeito. Algo da ordem do ditado popular "se correr o bicho pega, se ficar o bicho come". Acompanhemos o autor: 
Freud demonstra como a renúncia ao gozo alimenta o gozo da renúncia. Mesmo quando não há prazer, pode haver gozo, e vice-versa (...). O gozo atormenta tanto quem se entrega quanto aqueles que se negam a ele. (Vieira, 2008, p. 89-90)

Da mesma forma, Braunstein (2007) faz uso das seguintes palavras para abordar o mesmo importante paradoxo. Trata-se da mesma ideia, dita de outra maneira:

Cabe aqui recordar a sagaz observação clínica de Freud: a obediência ao Supereu, o sacrifício do gozo fálico para satisfazer suas exigências não acarreta a paz interior, mas quanto mais 'virtuoso' se é, mais se encontra o sujeito assediado pelos escrúpulos e pela culpa. As renúncias pulsionais não fazem senão incrementar o mal-estar tanto no indivíduo quanto na cultura. (Braunstein, 2007, p. 326)

Por trás deste paradoxo, podemos dizer com Cottet (1989, p. 8), estaria a interpretação que Lacan dá ao assassinato do pai freudiano, o pai tirano da horda primeva de Totem e Tabu (1912-13/1996): "não somente o assassinato do pai vai abrir o caminho do gozo que a sua presença parecia interditar mas reforça a proibição." O reforço desta proibição, segundo Rudge (1998), adviria precisamente da culpa gerada pelo parricídio que vai introduzir a renúncia aos desejos e as restrições morais. Tal fenômeno, segundo a autora, seria indispensável ao advento da cultura.

\subsection{Freud e os pilares do gozo}

O prazer de chupar o dedo, o gozo da sucção, é um bom exemplo de tal satisfação auto-erótica partida de uma zona erógena. (Freud, 1910[1909]/1996)

$\mathrm{Na}$ frase escolhida para abrir esta parte do trabalho, Freud utiliza os termos 'gozo' ('genuss') e 'prazer' ('lust') aparentemente como sinônimos, mas é possível também, podemos inferir, que o psicanalista de Viena tenha intuitivamente se corrigido a tempo. Mesmo sem ter concebido o conceito de 
gozo, tal como o fez Lacan, Freud parece ter acertado ao substituir o termo prazer por gozo ao se referir ao ato de chupar o dedo, que realmente está muito mais para gozo, tal como concebido por Lacan, do que para prazer. Pensemos a respeito: chupar o dedo não alimenta, é um ato solitário, conjuga dor e prazer e (aparentemente) 'não serve para nada', todas são características marcantes do conceito lacaniano de gozo. Pode-se comparar, sem susto, o ato de chupar o dedo do bebê à masturbação do adulto. Para que servem? Como responderia Lacan, ironicamente: para nada! Apenas para desperdiçar sêmen e energia... isso é gozo! Algo da ordem do desperdício, mas cuja função é valiosíssima para o sujeito.

Mais utilizado do que se imagina por Freud, o termo 'gozo' ('genuss') aparece em sua obra com diversos significados, dentre eles, segundo Couto (2006), podemos citar os seguintes: 'o gozar da civilização, dos privilégios e das boas coisas da vida'; 'gozar da realização de desejo'; ' gozar de uma obra de arte'; 'gozar do ganho secundário de uma doença'; 'gozar do prazer humorístico'; 'gozo sexual', etc. Percebe-se assim que Freud não tratou do gozo enquanto conceito psicanalítico, mas como um termo qualquer da língua alemã ('genuss'). Vejamos algumas dessas passagens do inventor da psicanálise:

Uma satisfação irrestrita de todas as necessidades apresenta-se-nos como o método mais tentador de conduzir nossas vidas; isso, porém, significa colocar o gozo antes da cautela, acarretando logo o seu próprio castigo. (1930[1929]/1996, p. 85)

Em troca de uma alma imortal, o Demônio tem muitas coisas a oferecer, que são altamente prezadas pelos homens: riqueza, segurança quanto ao perigo, poder sobre a humanidade e as forças da natureza, até mesmo artes mágicas, e, acima de tudo o mais, o gozo — o gozo de mulheres belas. (1923[1922]/1996, p. 95)

As representações obsessivas, quando seu significado íntimo é reconhecido pela análise, quando se reduzem, por assim dizer, a sua expressão mais simples, nada passam de recriminações dirigidas pelo sujeito a si mesmo por causa desse gozo sexual antecipado, mas recriminações distorcidas por um trabalho psíquico inconsciente de transformação e substituição. (1896/1996, p. 154)

Apesar de não haver conceituado o gozo, Freud parece que esteve bem próximo disso em pelo menos duas passagens, conforme observa Valas (2001). O autor pinça na obra freudiana dois episódios que expressam esta característica fundamental do conceito lacaniano: o gozo enquanto 'prazer dolorido'. No 
primeiro deles, Valas (2001) faz referência à 'expressão estranha' no rosto do Homem dos Ratos, no momento em que o analisando de Freud discorre sobre o 'suplício chinês da penetração de um rato no ânus', expressão esta interpretada pelo mestre vienense como de um "horror ao gozo ('genuss') todo seu do qual ele mesmo não estava ciente" (Freud, 1909/1996, p. 150). Do mesmo modo, o autor observa que Freud nota uma espécie de jubilação mórbida no rosto de seu neto, enquanto este trata de dar conta da angústia diante da presença-ausência de sua mãe, utilizando como recurso para tal empreitada seu famoso jogo de carretel, conhecido como 'Fort-da'. Segundo Valas (2001), é como se o menino de 19 meses sentisse, na dor desse jogo, uma espécie de prazer. Um prazer dolorido.

Em mais uma aproximação, Freud tangencia a ideia do gozo lacaniano ao referir-se na seguinte passagem a 'pulsões perversas' e 'coisas proibidas'. Perversão e transgressão são duas ideias afins ao conceito de gozo. Cito Freud: "A irresistibilidade das pulsões perversas e, talvez, a atração geral pelas coisas proibidas encontram aqui uma explicação econômica" (1930[1929]/1996, p. 87).

Em outro momento do mesmo texto, 'O mal-estar na civilização', o desbravador Freud, ao discorrer sobre os 'veículos intoxicantes', aborda outra característica fundamental do gozo: o desperdício, aquilo que Lacan viria a chamar de 'entropia', conforme classificado por Miller (2012) em seu quinto paradigma do gozo. Acompanhemos Freud: "São responsáveis, em certas circunstâncias, pelo desperdício de uma grande quota de energia que poderia ser empregada para o aperfeiçoamento do destino humano" (1930[1929]/1996, p. 86).

Lacan vai situar a ideia dessa perda, desse desperdício, dessa entropia típicos do gozo - naquele fenômeno psíquico bastante badalado que Freud chamou de 'compulsão à repetição'. Vamos a ele. 


\section{- Compulsão à repetição}

o que se repete não poderia estar de outro modo, em relação ao que repete, senão em perda. Em perda do que quiserem, em perda de velocidade, de força - há algo que é perda. Freud insiste desde a origem, desde a articulação que estou resumindo aqui, nessa perda - na própria repetição há desperdício de gozo. (Lacan, 1970/1992, p. 48)

A discussão mais importante de Freud a respeito do conceito de compulsão à repetição ('Wiederholungszwang') ocorre no texto "Além do Princípio de Prazer" (1920), onde relaciona tal fenômeno ao conceito de pulsão de morte. Freud defende a existência de uma 'compulsão à repetição' para dar conta de certos fenômenos que o intrigavam em sua clínica, em especial, a tendência do sujeito de reviver certas situações da ordem do traumático. Os sonhos de angústia (pesadelos), que reproduziam situações traumáticas vividas pelo sujeito repetidas vezes, também desafiavam Freud e seu 'princípio de prazer', como princípio regulador do psiquismo.

O conceito de compulsão à repetição foi responsável por uma reviravolta na teoria freudiana, conhecida como 'a virada de 1920'. A concepção deste importante conceito, além de abrir passagem para o desenvolvimento da noção de pulsão de morte, também foi responsável pela introdução de consideráveis modificações na técnica psicanalítica, no que diz respeito ao analista passar a dar mais ênfase àquilo que se repete e, portanto, insiste.

Além deste viés associado à perda e ao desperdício, a compulsão à repetição pode ser encarada como um importante recurso de simbolização e elaboração, uma tentativa de ligação de algo que se rompeu, estando desta forma associada não à pulsão de morte, mas à pulsão de vida. Senão vejamos: o famoso jogo de carretel conhecido pelo nome de 'Fort-da' realça o aspecto positivo da repetição, uma vez que na tentativa de elaboração/simbolização da presençaausência da mãe o sobrinho de Freud se entrega a este ritual repetitivo que, de longe, parece pura perda de tempo (e energia). Através deste ato repetitivo, a criança deixa a posição passiva e vai em direção à atividade; ela joga o carretel e o 
puxa de volta, na hora que ela bem entender; a posição do sujeito frente à angústia deixa de ser, portanto, passiva para ser ativa. Quem seria louco de interromper o menino do 'Fort-da', em pleno processo de simbolização? Quem teria coragem de arrancar o carretel da mão do menino? Perda de tempo e energia? Parece mas não é...

Levando-se em conta a tese de Freud de que além do princípio do prazer jaz a pulsão de morte, entende-se que é justamente ela, através das vozes e mandamentos do supereu, que incitaria tais fenômenos compulsivos, repetitivos e ilimitados, que Freud batizou de "compulsão à repetição".

\section{- Pulsão de morte e supereu}

Pois elidir a pulsão de morte de sua doutrina é desconhecê-la em caráter absoluto. (Lacan, 1966/1998, p. 817)

Segundo Rudge (2006), em um primeiro momento, a ideia de pulsão de morte não apresentou aplicação imediata nas teorias freudianas das neuroses e dos conflitos psíquicos, tendo persistido nas elaborações posteriores de Freud em função de dois aspectos principais: 1) a forte impressão causada em Freud pela Primeira Guerra Mundial, com toda sua violência e 2) as manifestações clínicas das neuroses traumáticas e dos fenômenos masoquistas, como a reação terapêutica negativa e os auto-ataques, que, segundo a autora, solicitavam serem levados em conta na teoria.

Freud vai pensar a pulsão de morte não apenas como uma tendência ao inorgânico por si só. Tal concepção seria insuficiente para dar conta, por exemplo, da destrutividade humana. Era preciso algo mais. Assim, de acordo com Rudge (2006), a pulsão de morte e a noção de um masoquismo que é primário fazem sua entrada na psicanálise em um mesmo momento, numa tentativa de Freud responder a um mesmo conjunto de problemas levantados pela clínica. Entretanto, segundo a autora, a questão da constituição dessa força "que empurra 
o homem para a dor e para o mal" permaneceu ocupando o centro de todas as formulações posteriores de Freud.

Neste salto, representado pela passagem da concepção da pulsão de morte enquanto força biológica até a ideia de uma destrutividade de ordem psíquica, o supereu é uma "mediação indispensável" (Rudge, 2006, p. 81). A autora argumenta que os mesmos fenômenos clínicos que levaram Freud a conceber a pulsão de morte - reação terapêutica negativa e masoquismo - são apresentados em 'Inibição, sintoma e angústia' (1926) como "manifestações da tirania de um supereu sádico sobre o eu" (Rudge, 2006, p. 82). Dentre os tipos de resistência que ameaçam uma análise, a resistência do supereu é identificada por Freud como a mais radical delas.

A partir da articulação da pulsão de morte com o supereu, nos distanciamos do apoio biológico inicial em direção a uma concepção histórica da pulsão de morte, apoiada no desamparo do bebê humano e no que é construído a partir do campo social. Ensina Freud: "o desamparo inicial dos seres humanos é a fonte primordial de todos os motivos morais" (1950[1895]/1996, p. 370). O supereu, enquanto "introjeção de coisas ouvidas" (Rudge, 1998, p. 62) traz estampada a marca de um Outro primordial.

Uma articulação interessante é aquela que compara o supereu freudiano ao pai do Complexo de Édipo - aquele 'representante da lei', que interdita o acesso da criança à mãe, proibindo o incesto e, consequentemente, o gozo; enquanto que o supereu lacaniano teria como representante o pai da horda primeva, de Totem e Tabu (Freud, 1912-13), que, mesmo depois de morto, continua 'do além' instigando seus filhos, a gozarem (Goza!), assim como ele próprio fazia em vida ao gozar, com exclusividade, das fêmeas do bando. "Nada força ninguém a gozar, senão o supereu. O supereu é o imperativo do gozo - Goza!”, diz Lacan (197273/1985, p. 11). Este pai mítico, tirano e paradoxal, ao mesmo tempo em que manda seus filhos gozarem, os pune exatamente por fazerem aquilo que ele próprio ordena. Vejamos como Braunstein (2007) apresenta esta distinção entre os chamados 'supereu freudiano' e 'supereu lacaniano': 
O supereu lacaniano não pode ser confundido com o freudiano. Seu imperativo não é o de obedecer, mas o de gozar e o gozo é justamente o que o supereu freudiano proíbe. (Braunstein, 2007, p. 327)

Tamanho poder desfrutado pelo supereu em relação ao eu, advém do que Freud chamou de "lembrança de uma antiga fraqueza". Ensina Freud (1923/1996):

(O supereu) preserva, não obstante, através de toda a vida (...) a capacidade de manter-se à parte do eu e dominá-lo. Ele constitui uma lembrança da antiga fraqueza e dependência do eu, e o eu maduro permanece sujeito à sua dominação. Tal como a criança esteve um dia sob a compulsão de obedecer aos pais, assim o eu se submete ao imperativo categórico do seu supereu. (Freud, 1923/1996, p. 61)

O masoquismo, por sua vez, é promovido à categoria de "originário", como resposta à percepção clínica de Freud desta força que luta contra a cura do analisando, mantendo-o na dor e no sofrimento e, por mais paradoxal que pareça, obtendo prazer a partir daí. Qualquer semelhança com o conceito lacaniano de gozo em seu aspecto de prazer dolorido não é mera coincidência. Lacan releu Freud, e fez isso muito bem.

Outra visada interessante do fenômeno do masoquismo, concebida por Rudge (1998), é a que o compara a um "resto de pulsão de morte". Acompanhemos a autora:

O masoquismo corresponderia a um resto de pulsão de morte que não foi desviada para fora pela libido através do aparelho muscular, como pulsão de destruição, domínio ou poder. (Rudge, 1998, p. 62)

Tão ou mais controverso que o gozo lacaniano, a pulsão de morte freudiana ('todestrieb') também pode ser caracterizada, ao contrário do que aparenta, como uma espécie de potência silenciosa, destrutiva sim, por um lado, mas criativa por outro. Tanto o gozo lacaniano, mais precisamente em seu terceiro paradigma 'gozo impossível'-, conforme apontado por Miller (2012), quanto a pulsão de morte freudiana têm esse mesmo caráter transgressivo e disruptivo. Ambos se manifestam sacudindo o status quo, abrindo espaço para o novo, para a criação; traição no lugar de tradição; movimento ao invés de estagnação. 
A pulsão de morte enquanto potência criadora e estruturante, pode ser assim vislumbrada na medida em que, através da sua face disruptiva e desagregadora, permitiria, por exemplo, a separação do infans da mãe, ação esta fundamental para a constituição do sujeito enquanto ser falante. Acompanhemos Garcia-Roza (1986) em seu enaltecimento da pulsão de morte:

É, pois, pela ação da pulsão de morte que se dá a separação e a constituição do objeto. O que até então era visto como algo puramente negativo - a pulsão de morte - passa a ser considerado como um princípio de constituição do objeto e responsável pela estruturação do psiquismo. (Garcia-Roza, 1986, p.77)

É como se ao invés de 'construções em analise' (Freud, 1937), tivéssemos, como efeito da incidência positiva da pulsão de morte na clínica, algo que propomos chamar de 'desconstruções em análise'. Ou seja, uma espécie de destruição criativa, diretamente relacionada ao significante 'análise', cuja etimologia nos remete às ideias de 'desligamento', 'dissolução', 'separação', 'libertação' e 'descolamento'. Descolar significado de significante, sim! Retirar sentido e não dar sentido! Isso é análise. Desconstrução e criação lado-a-lado. Compartilhando desta mesma visão da pulsão de morte enquanto potência criativa, Braunstein (2007) aborda a questão da seguinte maneira:

Esta vontade de destruição que é, segundo Sade, uma vontade de criação a partir do nada e recomeçar. Esta força destrutiva e criadora está ligada à história como memorável e memorizada, suspensa da existência da cadeia significante. (Braunstein, 2007, p. 62)

Podemos apreender esta mesma ideia a partir da seguinte passagem com a qual o gênio inventor da psicanálise conclui um de seus textos mais belos, chamado "Sobre a transitoriedade" (1916[1915]/1996). Diz Freud: "Reconstruiremos tudo o que a guerra destruiu, e talvez em terreno mais firme e de forma mais duradoura do que antes" (Freud, 1916[1915]/1996, p. 319). 


\subsection{Gozo e prazer}

Acrescento que a oposição entre o prazer e o gozo é essencial. o princípio do prazer aparece, de algum modo, como uma barreira natural ao gozo e, portanto, a oposição se estabelece entre a homeostase do prazer e os excessos constitutivos do gozo. (Miller, 2012, p.14)

Para nos auxiliar na compreensão deste conceito-chave da obra lacaniana - o gozo - vejamos como este se relaciona com o princípio de prazer de Freud. O princípio de prazer funciona como uma espécie de limite ao gozo. De acordo com o princípio de prazer, o sujeito deveria gozar apenas o possível, para que seja capaz de continuar gozando no dia seguinte. Sendo o conflito psíquico a base da teoria freudiana, e considerando a impossibilidade de uma compatibilidade harmoniosa entre pulsão e cultura, o sujeito insistentemente almeja transgredir as proibições impostas ao seu gozo para ir "além do princípio de prazer". Entretanto, o resultado desta transgressão não é mais prazer, senão dor, pois o que é prazer por um lado, por outro é desprazer. Além deste limite, o prazer é acompanhado de dor e sofrimento, e este prazer dolorido é o que Lacan chamou de gozo. Cottet (1989, p. 21) coloca a questão da seguinte forma: "há uma zona do prazer que é perigosa, essa zona que tende a ir para o gozo e que o princípio do prazer bloqueia".

O princípio de prazer é um dos dois princípios do funcionamento mental apresentados por Freud em seus escritos metapsicológicos (o outro é o princípio de realidade), sendo caracterizado, resumidamente, pela evitação do desprazer, e pela busca pelo prazer, visando manter a excitação do aparelho psíquico no menor nível de tensão possível. Prazer, para Freud, está relacionado à diminuição da quantidade de excitação no psiquismo, enquanto que o desprazer adviria do aumento desta quantidade. Dentre as contradições e paradoxos que permeiam a construção do conceito de princípio de prazer por Freud, está o fato de que o prazer nem sempre condiz com a redução de tensão, uma vez que a excitação sexual, por exemplo, é sentida como prazerosa ao mesmo tempo em que representa um aumento de tensão (Rudge, 1998). Como forma de lidar com tais 
ambiguidades, Freud passa a admitir, em 1920 (no Além do Princípio de Prazer), que existem sim tanto "tensões prazerosas" como "distensões desprazerosas".

Em sua obra, Lacan utiliza os dois termos - gozo e prazer - de maneira bem diferente. O prazer obedeceria à lei da homeostase, ou seja, buscaria compatibilizar a busca do prazer com o propósito de evitar o desprazer. A formação do sintoma neurótico, como formação de compromisso, é a melhor ilustração desta tendência. Já o gozo insiste em transgredir esta lei, estando assim para além do princípio de prazer. Sobre esta barreira representada pelo prazer no caminho até o gozo, Miller (1997, p. 204) vai deixar claro que "no caminho até o cume do gozo há um obstáculo, para qualquer pessoa (...). O obstáculo no caminho até o gozo é o prazer".

A partir desta interessante e paradoxal passagem de Miller, o princípio de prazer, que antes precisava ser limitado pelo princípio de realidade, aparece, agora, como limitador - funcionando como "uma barreira natural ao gozo". O mesmo princípio de prazer que outrora precisava ser domado pela intervenção do nome-do-pai, separando a criança da mãe (e vice-versa) para impedir o incesto, passa a representar - em uma sutil mudança de perspectiva - justamente um “obstáculo no caminho" até o incesto. Segundo o autor, o princípio de prazer é o que impede a consumação do primordial desejo incestuoso, ou seja, o que impede o gozo, regulando a distância entre o sujeito e a Coisa (Das Ding). Vejamos como Rudge (2006) articula princípio de prazer, pulsão e limite, destacando, assim como Miller (2012), o papel limitador do princípio de prazer:

Seguramente, é preciso um permanente trabalho para manter a pulsão operando dentro dos limites do princípio de prazer, uma vez que ela apresenta essas duas faces (vida e morte) que podem alternar. (Rudge, 2006, p. 83)

Potencializando esta saudável ambiguidade teórica, nos permitimos inferir que o gozo pode também estar em harmonia com o princípio de prazer, e nem sempre em oposição. Entrelaçados, gozo e princípio de prazer, podem bem servir como um poderoso recurso psíquico para escoamento dos excessos constitutivos e ameaçadores do psiquismo, protegendo o sujeito do pior. A ideia aqui é: ou o sujeito goza, ou pior. "Comer cabelo me tranquiliza", disse uma jovem em 
depoimento ao programa Fantástico de 19/08/12. Do quê fala esta jovem senão da intimidade e singularidade da relação com seu gozo? Mais precisamente, o que ela está falando é disso que propomos chamar de função estabilizadora/apaziguadora do gozo, justamente isso que, segundo ela, a tranquiliza. Como pode? Um gozo tranquilizador? Não costumam dizer e escrever por aí que o gozo perturba $e$ desestabiliza? Estamos, portanto, diante de um importante paradoxo do gozo. $\mathrm{Ou}$ seja, ao mesmo tempo em que o gozo pode perturbar, ele também pode tranquilizar, ao mesmo tempo em que está para "além" ele também pode estar em harmonia - nem sempre em oposição - ao princípio de prazer. A função estabilizadora/apaziguadora do gozo é uma das ideias que pretendemos realçar ao longo do trabalho, contando, desde já, com a valiosa contribuição de Miller (2012):

No Seminário sobre Os quatro conceitos, o modelo da relação com o gozo é a arte, o quadro, a contemplação pacífica do objeto de arte. Como diz Lacan, a obra de arte acalma as pessoas, ela as reconforta e lhes faz bem. (Miller, 2012, p. 17)

O famoso vertimento d'água, recurso de que as usinas hidrelétricas volta e meia lançam mão quando há ameaça de transbordamento da água da represa invariavelmente em decorrência de um excesso de chuva - ilustra bem essa função estabilizadora/apaziguadora do gozo, a qual nos referimos. Apesar de representar uma "perda" e trazer consigo algumas consequências danosas, o vertimento d'água é sempre a melhor alternativa ao transbordamento da represa. Portanto, seja para gozar (ou verter água) há que se pagar um preço. Porém, ou verte-se água (goza-se), ou pior. A seguir, trechos de notícias veiculadas no mês de maio de 2011 (www.g1.com.br; www.bbc.co.uk), sobre o último grande vertimento d’água realizado no rio Mississipi, servem para auxiliar na compreensão da nossa comparação do gozo com a água vertida da represa:

'Rio Mississipi: comportas são abertas para evitar catástrofe.' / 'Comportas são abertas para proteger cidades de cheia do Rio Mississippi.' / 'Inundação planejada na Louisiana deve afetar 25 mil pessoas.' / 'Objetivo é proteger as duas principais cidades do estado americano.' / 'Engenheiros do Exército dos Estados Unidos abriram, neste sábado (14), um desaguadouro a fim de permitir que as águas do rio Mississippi alaguem milhares de casas e hectares de cultivo, mas com o intuito de proteger as duas maiores cidades do estado de Louisiana.' / 'A medida, tomada pela última vez em 1973, pretende canalizar a água para casas, fazendas, áreas selvagens e uma pequena refinaria de petróleo na bacia do rio Atchafalaya, mas 
evitaria inundações em Baton Rouge e Nova Orleans.' / 'A não abertura das comportas poderia provocar riscos de inundações em Nova Orleans, que, de acordo com simulações feitas em computador, poderiam ser piores que as provocadas pelo furacão Katrina, em 2005, quando 80 por cento da cidade ficou inundada. Cerca de 1.500 pessoas morreram no desastre.' / 'Foi uma necessidade porque se o rio tivesse sobreposto a represa levaria consigo toda a população da área e teria causado cinco vezes mais danos do que a abertura.' / 'Os diques estão sob muita pressão por causa do volume de água passando por eles, por isso tivemos de fazer essa pequena abertura.'

A partir dos trechos selecionados, podemos perceber que tanto no caso da represa quanto em nosso psiquismo, melhor essa "pequena abertura", essa "perda", esse "vertimento", esse "gozo", do que o temível transbordamento, com suas graves consequências, tanto materiais quanto psíquicas. Em nosso entendimento, esta água vertida da represa, para evitar o pior, pode ser comparada ao gozo. Verter água de uma represa nada mais é do que promover uma inundação controlada, digamos, segura. Interessante observar que a água vertida não passa pelas turbinas da usina e, portanto, não gera energia, mas, mesmo assim, é a melhor alternativa ao transbordamento e à inundação súbita que costumam causar sérios prejuízos. A ideia do gozo lacaniano pode ser remetida à imagem desta água em excesso, que é vertida (perdida) e, consequentemente, não passa pela turbina. Ou seja, o gozo como ferramenta para lidar com os excessos que ameaçam 'inundar' a psique. Tanto o gozo da psicanálise, como o vertimento d’água da usina hidrelétrica, teriam como função primordial lidar com os excessos que ameaçam inundar o sistema, cada qual da sua maneira singular.

Em seu seminário 20, Lacan responde à pergunta formulada por ele próprio a respeito do que seria o gozo da seguinte forma: "O gozo é aquilo que não serve para nada" (1972-73, p. 11). Em nossa metáfora da usina hidrelétrica, a água vertida, pode-se dizer, também não serve para nada; pois não passa pela turbina e, consequentemente, não gera energia, carregando em si, ao mesmo tempo, a marca de uma perda e de um excesso; um excedente de água que precisou ser vertido (perdido) para não causar o temível transbordamento. Ou verte-se a água, ou pior. Acompanhemos Miller (2012) na descrição de seu quinto paradigma do gozo: "desde então, o acesso ao gozo não se dá mais, essencialmente, através da transgressão, mas através da entropia, do desperdício produzido pelo significante" (2012, p. 32). 
Neste ponto, cabem algumas considerações a respeito desta intrigante ideia lacaniana de que o gozo não serviria para nada (Lacan, 1972-73/1985), sendo frequentemente relacionado à perda e ao desperdício. Obviamente, o gozo seria aquilo que aparentemente não serve para nada, mas que, na verdade, é valiosíssimo, assim como a obra de arte (objeto que Lacan e Miller utilizam frequentemente de apoio para falar do gozo).

De acordo com o que vimos até aqui, o princípio de prazer pode ser encarado como uma espécie de "guardião" de um estado de homeostase e constância o qual o gozo insistentemente ameaça romper. Esta insistência é descrita por Freud naquele fenômeno que batizou de compulsão à repetição e que pode ser descrito como uma espécie de retorno de um excesso (gozo), que insiste em retornar à cena, ameaçando transgredir os limites impostos pelo princípio de prazer. É o prazer funcionando como limite ao gozo, como guardião da vida, diz Lacan: "pois é o prazer que traz ao gozo seus limites, o prazer como ligação da vida" (1966/2008, p. 305).

Uma vez que o princípio de prazer está relacionado à proibição, à lei e à regulação, podemos posicioná-lo no registro do simbólico, enquanto que o gozo encontra-se do lado do real. Esta vertente do conceito de gozo que o vincula à quebra da barreira imposta pelo princípio de prazer, somada à ideia de que este só pode ser alcançado por meio de uma transgressão, permite-nos concluir, de forma paradoxal, que somente uma proibição poderia abrir o caminho até o gozo. Com outras palavras, o gozo precisa da lei para existir.

A partir do momento em que a lei é instaurada, instituída, toda a transgressão implicará um gozo - porque goza-se na transgressão, que fique claro isso - e isso, obviamente, acarretará uma dívida. Em outras palavras, gozar tem seu preço e esse preço, pode às vezes ser pago com a própria vida. Vejamos o que diz Cottet a respeito desta questão (1989, p. 29):

(...) aí, a partir desse momento, o sujeito pode preferir o gozo à vida, e é por isso que temos um complexo do gozo compatível com a aceitação da morte, isto é, de um imperativo de gozo mais forte do que a vida. 
Trechos extraídos de algumas notícias veiculadas sobre a morte de uma estudante de 20 anos em um cruzeiro universitário, em 2008, servem para ilustrar e trazer a teoria para o dia-a-dia:

Amostras de sangue do corpo da estudante de 20 anos, que morreu a bordo de um cruzeiro universitário, foram levadas para serem analisadas pelo Instituto MédicoLegal (IML) (...) afirmaram que houve consumo de drogas durante a viagem. (...) O delegado da Polícia Federal em Santos, no entanto, não descarta a possibilidade de que a passageira tenha morrido por ingestão conjunta de álcool e drogas A estudante morreu em consequência de asfixia por aspiração de líquido - vômito segundo o laudo do IML.

A entrada do sujeito na ordem simbólica da linguagem é condicionada a certa renúncia inicial de gozo (castração), quando o sujeito desiste de ser o falo imaginário da mãe. Gozo este que o sujeito busca insistentemente e inconscientemente recuperar; muitas vezes, na base do perigoso 'custe o que custar'. Em suma, pode-se dizer com Valas (2001, p. 43) que "o gozo pode ir das cócegas, passando pelo prazer refinado da dor, pela felicidade, pelo êxtase, até o horror que acompanha a grande chama mortal para o corpo".

\subsection{Paradigmas do gozo}

Eles (paradigmas do gozo) foram previstos para tentar recompor (...) o movimento que anima o que chamamos de ensino de Lacan, no que concerne à doutrina do gozo. (Miller, 2012, p. 1)

O conceito de gozo, introduzido pelo psicanalista francês Jacques Lacan, ostenta até os dias de hoje o status de um dos conceitos mais "complexos" dentro da psicanálise. Repleto de paradoxos, Lacan tratou do gozo a partir de diversas perspectivas que foram objeto de uma tentativa de sistematização por parte de Jacques-Alain Miller, em texto fartamente citado e conhecido, chamado "Os seis paradigmas do gozo" (2012).

Neste texto, Miller (2012) empreende uma classificação e organização dos diferentes movimentos, percebidos pelo autor, no percurso lacaniano de 
concepção e construção do conceito psicanalítico de gozo, os quais o autor chamou de "seis paradigmas do gozo". O primeiro deles - "a imaginarização do gozo" - especifica as consequências do primeiro movimento no ensino de Lacan daquilo que diz respeito à doutrina do gozo, movimento este profundamente marcado pela noção de um inconsciente estruturado como uma linguagem. Dentro desta concepção estruturalista inicial, Lacan enfatiza a ideia da autonomia do simbólico, da lógica e exigências próprias da cadeia significante. O gozo é aqui concebido como a falsa completude imaginária, que serve de testemunho acerca da maneira como o sujeito evita a verdade do seu desejo. Este paradigma corresponderia, mais especificamente, àquilo que Lacan retoma do libidinal em Freud chamando-o de gozo imaginário, representando, deste modo, uma barreira à elaboração simbólica. Elucida Miller (2012, p. 4): “o simbólico não é todo, ele deixa fora de si o imaginário que é outra ordem de realidade na qual se cumpre uma outra ordem de satisfação". Ou seja, resistindo à satisfação simbólica satisfação esta que é da ordem da comunicação - subsiste a satisfação imaginária, identificada por Miller como gozo. O gozo imaginário desta primeira concepção lacaniana não procederia da linguagem ou da fala, nem, portanto, do sujeito. Neste primeiro paradigma, o gozo representa justamente aquilo que resta, aquilo que fica de fora do processo de subjetivação (entrada na linguagem). Outra característica importante deste gozo imaginário, segundo Miller (2012), é que ele não é intersubjetivo, mas intraimaginário. Dito de outra forma, este gozo não é dialético, ou seja, não advém da relação, mas sim da estagnação e da inércia.

Ali, onde a elaboração simbólica falha ou fracassa, emerge o gozo imaginário, aparecendo na clínica, por exemplo, em um 'acting out' ou através de perversões transitórias. A tarefa da psicanálise seria, portanto, a de escutar e decifrar os sintomas através dos quais o sujeito goza, utilizando para tal empreitada a interpretação. Aquilo que substituiria o gozo, com efeito, seria o conhecimento por parte do sujeito do significado (inconsciente) do seu sintoma.

Outra importante articulação proposta por Miller (2012), ainda dentro deste primeiro paradigma, é aquela que diz respeito ao gozo e ao supereu. Como vimos, o tal fracasso simbólico proporciona o surgimento de um supereu "obsceno $e$ feroz" que vai tomar a figura do gozo imaginário. Ou seja, "Goze!” Não amanhã, 
não daqui a pouco, não parcialmente, mas sim aqui, agora e integralmente, até o limite (ou além). O que importa é o prazer imediato e ilimitado, sem contenção e sem barreira. Como enuncia Melman (2003), logo no título de seu livro, o que se busca é "gozar a qualquer preço". Sobre a origem e a eficácia desses "mandatos superegóicos”, Rudge (2006) ensina o seguinte:

Os mandatos superegóicos resultam de identificações com o que, nos pais, é desejo inconsciente, e subjugam o sujeito com especial eficácia porque operam, em sua quase-totalidade, de forma inconsciente. (Rudge, 2006, p. 85)

Este primeiro paradigma apresenta logo de saída um paradoxo, pois, conforme observa Miller (2012):

De um lado, o imaginário é certamente o que permanece fora da apreensão simbólica, ao passo que, do outro, Lacan acrescenta sempre que esse imaginário é, ao mesmo tempo, dominado pelo simbólico. (Miller, 2012, p. 6)

Ao invés de apressar-se em resolver esta aparente "contradição", o autor sustenta e valoriza a tensão gerada entre a autonomia do imaginário e a ideia da dominação do imaginário pelo simbólico, lembrando-nos, entretanto, que em Lacan não faltam referências de que o imaginário serve de material ao simbólico e, consequentemente, de material ao sintoma.

O segundo paradigma, o da "significantização do gozo", é considerado como um segundo movimento no ensino de Lacan, que não sucede simplesmente ao primeiro, mas mistura-se a ele, impondo-se progressivamente até dominá-lo inteiramente. Neste momento de simbolização do imaginário, Lacan vai deslocar o falo de seu estatuto imaginário, passando a privilegiar seu aspecto simbólico - o falo enquanto significante, e propõe também a redução da pulsão a uma cadeia significante "escrita a partir do sujeito simbólico, da demanda" (Miller, 2012, p. 8). Ao introduzir a demanda do Outro na sua fórmula da pulsão, Lacan reescreve definitivamente a pulsão em termos simbólicos. Do mesmo modo, em relação ao conceito de fantasia, Lacan vai demonstrar que não existe fantasia que não seja assimilável a uma cadeia significante, pois não existe fantasia que não seja cenário. Daí o tratamento dispensado à fantasia como ponto nodal onde o imaginário e o simbólico se concentram. 
O processo de "significantização do gozo" é levado tão a sério por Lacan que ele chega a compará-lo ao significado de uma cadeia significante inconsciente, cujo vocabulário, segundo Miller (2012), seria constituído pela pulsão. Seria precisamente isto - a "significantização do gozo" - o que Lacan chamou de desejo. Miller (2012, p. 9) utiliza ainda as expressões gozo mortificado e gozo transposto para o significante para designar este gozo capturado pela rede simbólica, cuja satisfação é análoga à do desejo, ou seja, satisfação pura da metonímia. Trata-se aqui do apagamento do gozo pelo significante - "o significante anula o gozo e o restitui sob a forma de desejo significado" (Miller, 2012, p. 10). Seguindo a mesma lógica, o autor argumenta que o gozo não é outra coisa senão desejo morto, situando-o repartido entre o desejo e a fantasia. Desejo morto de um lado e fantasia que comporta a vida do outro. Eis aí o gozo em seu segundo paradigma.

A terceira concepção de gozo em Lacan, segundo Miller (2012), é aquela que diz respeito ao "gozo impossível", ou seja, ao gozo atribuído ao real. Este é o paradigma do gozo que nos remete à ideia de "a Coisa" ('das Ding'), conceito nascido em Freud e desenvolvido por Lacan, que o autor relaciona à noção de verdadeira satisfação ou satisfação pulsional propriamente dita. Um tipo especial de satisfação que não se encontra nem no imaginário, muito menos no simbólico (por estar fora do que é simbolizável), sendo, portanto, da ordem do real. Sobre este gozo relacionado à Coisa, Lacan vai dizer o seguinte: "porque o desejo vem do Outro, e o gozo está do lado da Coisa." (Lacan, 1966/1998, p. 867). E o que seria estar do lado da Coisa? Com Braunstein (2007, p. 78), podemos dizer que estar do lado da Coisa seria estar no campo do real puro, anterior a qualquer simbolização ("intrusão da linguagem na carne”). Simbolização esta que, segundo o mesmo autor, é responsável por induzir à "falta a ser que caracteriza o sujeito e o lança por veredas de desejo".

Para conter e redirecionar o poderoso empuxo ao impossível "gozo real" que insiste, persiste e retorna, é necessário toda uma estrutura, toda uma montagem simbólico-imaginária. A barreira simbólica da lei ("tu não deves"; "tu não podes") e a barreira imaginária que nos ilude e desvia nosso olhar antes mesmo do "franqueamento em direção à Coisa" (Miller, 2012, p. 12), servem para 
impedir o acesso à mãe - objeto por excelência - que ocupa o lugar de 'das Ding'. Ter levado uma significantização do gozo a seu termo, exige de Lacan situar "o gozo impossível", "gozo da Coisa" fora do significante. Neste paradigma, portanto, o gozo passa para o registro do real, sendo descrito como "fora do sistema" e reduzido a um lugar vazio, abissal, estruturalmente inacessível, a não ser pelo viés da transgressão. O elogio da transgressão heroica no seminário sobre a ética (1959-60/2009), advém do fato de que para se romper com a tradição, há que haver transgressão. Eis o valor deste paradigma do gozo que rompe com as estruturas pré-estabelecidas, impondo uma traição-transgressão do status quo simbólico-imaginário, abrindo assim espaço para o novo, para a novidade. Tratase, de acordo com Miller (2012, p. 15), também, de "uma oposição entre o que é engodo, de um lado - aquele do prazer, do significante, do imaginário e do semblante - e, do outro lado, o que é real". A perspectiva se desloca do enaltecimento da estrutura e sua lei para o fascínio pelo ato heroico transgressivo e suicida, que exclui o sujeito da comunidade simbólica.

Definido como o paradigma do "gozo normal", a quarta concepção do conceito de gozo está no Seminário 11 de Lacan (1964/2008) e representa uma "nova aliança" estabelecida entre o simbólico e o gozo. Este gozo, segundo Miller (2012), estaria situado não mais em um abismo, como no terceiro paradigma, mas em uma "cavidade" - um gozo fragmentado em objetos a situados em uma cavidade do corpo. Neste paradigma, o modelo da relação com o gozo é a arte, a obra-de-arte em sua contemplação pacífica que acalma as pessoas, ou seja, um modelo diametralmente oposto ao anterior, do gozo conectado ao horror da terrível fragmentação corporal. Neste quarto paradigma trata-se de um corpo simbólico, fragmentado em pulsões parciais e zonas erógenas autônomas, cuja integração se realizaria através de um gozo pulsional, "um gozo automático, alcançado ao se seguir o caminho normal da pulsão, seu ir e vir, e sem transgressão" (Miller, 2012, p. 17).

Do terceiro para o quarto paradigma, há um desmentido em relação à clivagem entre significante e gozo, a qual é abandonada, cedendo lugar a uma estreita articulação entre estes dois conceitos. O gozo passa a ser pensado como sendo ligado ao funcionamento significante. As duas operações designadas por 
Lacan como "alienação" e "separação" são utilizadas para ilustrar esta íntima relação entre o gozo e o simbólico. A "alienação" seria própria da ordem simbólica enquanto que a "separação" é pensada como uma resposta de gozo à primeira. Segundo Miller, aquilo que Lacan chama de "alienação" seria, em termos freudianos, o equivalente à unificação dos conceitos de identificação e de recalque. A identificação relaciona-se ao registro do simbólico na medida em que supõe um significante que representa o sujeito; um significante que está no Outro e com o qual o sujeito se identifica; "trata-se do que Lacan chama de divisão do sujeito" (Miller, 2012, p. 18). O recalque, por sua vez, refere-se àquele significante da cadeia que passa para baixo da barra e que assim vai representar o sujeito. A operação de "separação", em seu turno, surge como resposta da função da pulsão à identificação e ao recalque, sendo precisamente aquilo que resta e resiste ao processo de subjetivação. Referimo-nos aqui ao objeto pequeno $a$, esta unidade de gozo inventada por Lacan, como resposta ao vazio resultante da identificação e do recalque. Apresentando a libido como "objeto perdido", Miller (2012) vai dizer o seguinte sobre a separação e sua função:

De fato, ele chama de separação a recuperação da libido como objeto perdido e, assim, tenta mostrar, com seu aparelho, que ela responde, necessariamente, à falta propriamente significante que resulta da articulação entre identificação e recalque. (Miller, 2012, p. 20)

Este objeto perdido diz respeito a uma perda, uma falta natural e constitutiva do sujeito. Seria algo relacionado a uma perda de vida (gozo) que comporta, como tal, a existência do corpo do sujeito. Desta forma, os objetos da pulsão podem ser pensados como tendo a função de reparar e preencher esta perda originária. Neste paradigma o objeto $a$ aparece como elemento de gozo, ou seja, um recurso teórico de elementarização da Coisa, fazendo desta um elemento múltiplo, mais manejável clinicamente do que a Coisa em si.

Em seu quinto paradigma - o do gozo discursivo - Miller vai destacar o significante enquanto aparelho de gozo. Neste momento de seu ensino (seminário XVI, 1968-69/2008), Lacan introduz o gozo enquanto efeito do significante, ao mesmo tempo em que argumenta que o sujeito abre mão do gozo, paradoxalmente, como efeito do discurso. Seria o discurso, portanto, que causaria 
a perda de um gozo mítico e a subsequente tentativa de recuperá-lo; tentativa esta que podemos trazer para o campo do desejo. Enquanto causa de desejo, o objeto a pode ser representado por aquela parte de gozo perdido (mais-gozar) que pode ser recuperada - um suplemento de gozo que escapou à mortificação do simbólico. Em outras palavras, o objeto a como uma espécie de compensação pela perda causada pelo significante.

Neste paradigma, o objeto perdido - gozo - é efeito do significante, ou seja, o gozo seria alcançado não pela transgressão, mas pela perda causada pelo significante. Desta forma, estamos aqui diante de um importante paradoxo: ao mesmo tempo em que o significante causa uma perda de gozo, ele também produz um 'a mais' de gozo - como resposta a esta perda - na forma deste objeto especial chamado por Lacan de objeto a (mais-gozar). Temos, assim, uma espécie de circularidade primitiva entre significante e gozo, pois, ao passo que a introdução do significante depende do gozo, mais precisamente do corpo afetado pelo gozo, o gozo precisa do significante como ponto de apoio. Acompanhemos Miller (2012):

Primeiramente, o significante é causa do gozo, meio do gozo, o que quer dizer que o gozo é a finalidade do significante, e, num segundo momento, o significante emerge do gozo, posto que o comemora. (Miller, 2012, p. 37)

Há, portanto, no sujeito, um movimento de recuperação deste gozo perdido sob a forma de objeto $a$, em suas vertentes 'mais-gozar' $e$ 'causa de desejo'; uma insistente - e repetitiva - tentativa de preencher essa falta (de gozo) causada pelo significante. "É aí que Lacan valoriza a repetição como repetição de gozo", diz Miller (2012, p. 24); e o que estaria por trás, impulsionando essa repetição sintomática seria, justamente, a defasagem entre a falta $(-\varphi)$ e seu suplemento $(a)$.

O sexto paradigma do gozo, localizado por Miller (2012) nas formulações do Seminário XX: mais, ainda (1972-73/1985) - que em francês se chama 'encore', homófono de 'en-corps' ('no corpo') - refere-se ao gozo da não-relação. Aqui se trata de tudo do campo do gozo que parece funcionar sem o Outro. A ideia da não-relação, central neste paradigma, advém de certas disjunções identificadas por Lacan, como por exemplo, a disjunção entre significante $e$ significado, entre gozo e Outro, e também - por que não? - entre homem e mulher. 
Daí o famoso e controverso aforismo lacaniano de que a relação sexual não existe. Sobre esta afirmação controversa, Coelho dos Santos (2009) diz o seguinte:

Em seu Seminaire XX, Encore, Lacan (1972-1973/1984) parte do axioma de que não há relação sexual para trazer ao centro de sua teoria da constituição subjetiva as respostas, necessariamente distintas, que homem e mulher inventam para suprir essa ausência. (2009, p. 13)

Em seu vigésimo seminário, Lacan empreende uma mudança de perspectiva radical em relação ao gozo. Neste momento de seu ensino, a linguagem e sua estrutura aparecem como secundários e derivados do que Lacan vai chamar de 'lalangue'. Lalangue é um conceito inventado por Lacan e que diz respeito à fala antes do seu ordenamento gramatical e lexicográfico, o que a separaria, portanto, da linguagem tal como esta é concebida pelo linguista. O blablablá dos bebês é uma das formas de conceber o conceito lacaniano de lalangue - uma fala sem regras, sem ordenamento, sem significado a priori. Ou seja, a fala concebida, não como comunicação, mas como gozo (Miller, 2012) e que visaria, portanto, não a compreensão, mas o gozo. Assim, Lacan introduz um gozo originário, independente da estrutura (linguística) e suas articulações, abrindo espaço para a noção de não-relação e disjunção, fortemente presentes neste paradigma. Sobre aquilo que nomeia de "império da não-relação", levado ao seu extremo, Miller (2012) escreve o seguinte:

O império da não-relação chega até a questionar, na última parte do ensino de Lacan, a pertinência de se tentar operar sobre o gozo a partir da fala, a partir do sentido. Essa indicação é como se fosse o ápice ao qual o império da não-relação pode chegar e do que pode, nesse contexto, a invenção do discurso psicanalítico. (Miller, 2012, p. 41)

Há gozo, esta é a conclusão a que chega Lacan neste sexto paradigma, e só há gozo enquanto propriedade de um corpo vivo. O olhar de Lacan sobre o gozo se volta, portanto, para o corpo. Daí a razão para a homofonia existente no título em francês deste seminário - 'Encore' (Ainda) - que nos permite escutar também 'En-corps' (Em-corpo), neste interessante recurso linguístico frequentemente empregado por Lacan. O corpo passa a figurar em lugar de destaque na concepção lacaniana de gozo, uma vez que se trata, em suma, do corpo de um que goza de 
uma parte do corpo do Outro. É o corpo que está ali em questão e é sempre ele quem goza, "por qualquer que seja o meio", seja masturbando-se ou, simplesmente, falando. Diz Lacan (1972-73/1985):

Não é lá que supõe, propriamente, a experiência psicanalítica? - a substância do corpo, com a condição de que ela se defina apenas como aquilo de que se goza. Propriedade do corpo vivo, sem dúvida (...). Isso só se goza por corporizá-lo de maneira significante." (Lacan, 1972-73/1985, p. 35).

Eis o ponto de partida para a ideia lacaniana de disjunção (não-relação) entre o gozo e o Outro. A partir do momento em que só se pode gozar de uma parte do corpo do Outro, pois, segundo Lacan, “jamais se viu um corpo enrolar-se completamente, até incluí-lo e fagocitá-lo, em torno do corpo do Outro" (197273/1985, p. 35), há, então, disjunção. Tudo o que é do gozo, diz Miller (2012, p. 43), é "gozo Uno, quer dizer, gozo sem o Outro". Está aí o fundamento para a proposição lacaniana de que a relação sexual não existe.

\subsection{Tipos de gozo}

Esse gozo, conotado de castração, é o gozo fálico ou gozo do significante ou gozo semiótico, gozo hors-corps para distinguilo dos outros, gozo do ser e gozo do Outro, que são gozos do corpo, e, portanto, gozos hors-langage, fora da palavra, inefáveis. (Braunstein, 2007, p. 89)

No estado inicial de satisfação e completude mútua mãe-bebê, podemos encontrar aquilo que Lacan chamou de gozo do ser. Este momento mítico e irrecuperável seria experimentado antes da entrada do infans na linguagem, antes da falta e, portanto, do desejo. A função da linguagem, a propósito, é o que nos permite separar, de acordo com Braunstein (2003), três modalidades de gozo. São elas:

1) Gozo do ser, gozo antes da linguagem, experimentado na relação com o gozo da mãe, a partir da proximidade da Coisa; gozo inscrito no corpo, mas fora da linguagem; inominável, indizível, mítico; 
2) Gozo fálico (ou sexual), subserviente à castração, à lei e ao "Nome-dopai"; gozo inscrito na palavra, gozo do ser falante como tal, limitado pela linguagem por um lado e pela detumescência do órgão por outro;

3) Gozo do Outro (ou feminino), gozo além da palavra, além da regulação da lei e do falo; além, portanto, da castração; gozo misterioso e inefável, sendo impossível ao ser falante ('parlêtre') traduzi-lo em palavras.

A primeira modalidade, denominada gozo do ser - gozo do corpo, fora da linguagem (hors-langage) - é, segundo Braunstein, "gozo perdido pela castração" (2007, p. 133). Seria o gozo anterior à significação fálica e, portanto, fora do simbólico. Gozo vinculado à Coisa. O autor sustenta a distinção entre o real prévio e o real posterior ao discurso, que remete à ideia de um tempo lógico (não cronológico), e demonstra a função de corte - presente na palavra - entre a Coisa (anterior) e o objeto $a$ (posterior); entre um gozo do ser e outro gozo, efeito da castração (lei da linguagem), que é o gozo fálico.

O segundo tipo - gozo fálico ou gozo sexual - é articulado ao significante, à linguagem e, portanto, à lógica fálica, corroborando a elaboração freudiana da castração. "Graças à castração que o registro do gozo sexual nos é aberto", afirma André (1998, p. 212). O gozo fálico, portanto, adviria como efeito da passagem do sujeito pela castração, evocando e contornando o incesto (Braunstein, 2007). Uma visada interessante sobre o gozo dito fálico, e o fenômeno da castração, é a que podemos depreender do mito freudiano da horda primeva (Totem e tabu). Gozo fálico seria o gozo dos filhos pós-assassinato do pai tirano. Após o parricídio, um filho passa a vigiar o outro, de forma que aquele que vislumbre ocupar o lugar deixado pelo pai morto ('macho alfa') tenha medo de também ser morto pelos demais (castração). O pacto social se estabelece a partir daí, impedindo o retorno do gozo absoluto, outrora encarnado na figura do pai tirano.

O gozo fálico, de acordo com Lacan, é o tipo de gozo que estaria em consonância (não em oposição) ao princípio de prazer de Freud e, portanto, intrinsecamente delimitado pela lei, que é, com efeito, a lei da linguagem. Não por acaso, o gozo fálico é o que mais se aproxima da noção jurídica de 'usufruto', na medida em que, assim como no direito, o 'bem' principal (corpo) é preservado; 
consome-se apenas os juros, os excedentes, não o principal; dá para continuar jogando (ou bebendo) no dia seguinte. Demonstrando como o gozo sexual se articula ao significante fazendo, assim, limite ao gozo, André (1998) vai dizer o seguinte:

o gozo sexual é em si mesmo uma limitação do gozo em geral. O gozo sexual faz limite, porque depende do significante: é com efeito o significante que introduz a dimensão do sexual no ser humano. (André, 1998 p. 212)

O gozo fálico, também conhecido como gozo do órgão e gozo sexual, seria delimitado fundamentalmente pela detumescência do próprio órgão, após o orgasmo, fenômeno este que nos remete à ideia de castração. Sobre a existência dessa relação entre gozo e orgasmo, cito Braunstein (2007):

É verdade que há uma relação entre o orgasmo (que pode ser obtido por meio da cópula, mas não necessariamente por meio dela como o provam a masturbação, os sonhos eróticos e as emissões seminais em situações de angústia) e o gozo. (Braunstein, 2007, p. 126)

Vejamos o que diz Lacan sobre a limitação imposta pelo gozo fálico: "o gozo fálico é o obstáculo pelo qual o homem não chega, eu diria, a gozar do corpo da mulher, precisamente porque o de que ele goza é do gozo do órgão" (Lacan, 1972-73, p. 15). Ou seja, vemos aí o falo funcionando como limite ao gozo. Limite este que é, em última instância, corporal (detumescência do órgão = castração). O gozo feminino, por outro lado, escaparia desta limitação fálica, imposta pela ameaça de castração; pela flacidez do órgão após o orgasmo. E, portanto, ela pede 'mais' ('encore').

A terceira modalidade de gozo - gozo do Outro ou gozo feminino - foi concebida por Lacan como aquela que escapa à cadeia significante e à castração, estando, portanto, apartada da linguagem ('hors-langage') e, portanto no corpo ('en corps'). Acompanhemos Valas (2001):

Quanto ao gozo feminino, do qual o mito de Totem e tabu não fala - e por boas razões, pois ele fica à margem do processo da significância, ao qual ele é radicalmente estranho -, Lacan vai qualificá-lo como estando mais-além do falo, porque se situa fora do significante. (Valas, 2001, p. 45) 
Esse gozo do Outro, concebido como suplementar ao gozo fálico (maisalém do falo) é característico da constituição feminina. Enquanto o gozo fálico corresponderia às vicissitudes da castração, respondendo, portanto, às condições determinadas pelos processos inconscientes, o gozo do Outro equivaleria a um $a$ mais ('encore', homófono de 'en corps' = no corpo), apresentando-se foracluído do simbólico, não se adequando, portanto, à lógica do significante. Diz Valas: “O gozo feminino, definido como suplementar, além do falo, está fora da linguagem, fora do simbólico" (2001, p. 88). A mulher, para Lacan, não está toda submetida ao registro fálico, uma vez que é confrontada com um resto pulsional que não passou totalmente pela interdição. É este a-mais de gozo ('plus de jouir'), este gozo suplementar, que se acrescenta ao gozo fálico, inscrito na rede de significantes. Importante notar, entretanto, que este a-mais de gozo, este gozo outro do que fálico, só pode ser alcançado com apoio na própria castração, conforme observa Braunstein (2007):

O gozo do Outro, também corporal, que não foi perdido pela castração, mas que emergia além dela, efeito da passagem pela linguagem, mas fora dela, inefável e inexplicável, que é o gozo feminino. (Braunstein, 2007, p.133)

$\mathrm{O}$ autor vai dizer ainda que, enquanto no homem o orgasmo representa o ponto em que toda demanda cessa, na mulher, frequentemente a demanda subsiste, ou seja, não se esgota com a ejaculação do outro, ficando um saldo irresoluto que vai motivar justamente seu 'encore', seu apelo por algo mais. Um maior conhecimento da anatomia e da fisiologia feminina, conforme observado por Lacan (1962-63/2005), só fazem aumentar ainda mais o enigma do gozo feminino, principalmente quando revelam a falta de enervação da parede vaginal.

Aos olhos do homem, dirá Clavreul (1990, p. 100), a mulher teria a 'vantagem' de não passar pela vergonha da impotência, sendo sempre capaz de fingir ou negar seu gozo. Enquanto que para o homem, o ato sexual continua sendo uma 'prova de verdade', na qual salta aos olhos da(o) parceira(o) as disfunções de sua relação com o desejo e com o gozo. Gozo e desejo, inclusive, encontram-se intimamente entrelaçados, principalmente, no ato sexual. "Para o 
homem, ereção e ejaculação são inseparáveis de desejo e gozo", afirma Clavreul (1990, pág 99).

\subsection{Barreiras ao gozo}

I want to stay as close to the edge as I can without going over. Out on the edge you see all kinds of things you can't see from the center. ${ }^{19}$ (Kurt Vonnegut, Player Piano, 1952)

Quando basta? Há um limite consensual ou ele é absolutamente singular? É possível impor restrições ao gozo? Deleuze (1988-1989, "B” de "beber") nos oferece, logo de saída, sua valiosa contribuição em relação ao álcool:

O último copo quer dizer o seguinte: ele avalia, há uma avaliação, ele avalia o que pode aguentar, sem desabar... Ele avalia. Varia para cada pessoa. Avalia, portanto, o último copo e todos os outros serão a sua maneira de passar, e de atingir esse último. E o que quer dizer o último? Quer dizer: ele não suporta beber mais naquele dia. É o último que lhe permitirá recomeçar no dia seguinte, porque, se ele for até o último que excede seu poder, é o último em seu poder, se ele vai além do último em seu poder para chegar ao último que excede seu poder, ele desmorona, e está acabado, vai para o hospital, ou tem de mudar de hábito, de agenciamento. De modo que, quando ele diz: o último copo, não é o último, é o penúltimo, ele procura o penúltimo. (Deleuze, 1988-89, "B" de "beber")

Na mesma linha de Deleuze, Vieira (2008) apresenta da seguinte maneira a questão da demarcação do gozo, destacando a 'potência' presente no gozo fálico (intrinsecamente limitado):

No jogo em que o falo brilha, o gozo é intrinsecamente limitado. (...) Isso não quer dizer que o exercício desse gozo, chamado por Lacan de "gozo fálico", institua um poder frágil. Ao contrário, a limitação de que parte dá a ele uma santa vacina contra as vertigens do absoluto. Permite agir, construir, lutar, com a firmeza de quem vive a convicção de que, mesmo indo muito longe, poderá disputar o próximo campeonato. (Vieira, 2008, p. 91)

\footnotetext{
${ }^{19}$ Eu quero ficar tão perto da borda quanto eu possa, sem ultrapassar. Lá na borda você vê todos os tipos de coisas que você não consegue enxergar a partir do centro.
} 
Ao invés de perder tempo com barreiras externas ao gozo (facilmente transponíveis), o interesse dos analistas deveria voltar-se cada vez mais para o gozo e seus mecanismos internos de regulação. Quando falamos de um gozo "intrinsecamente limitado" falamos, mais especificamente, do gozo dito fálico, aquele gozo que, por mais contraditório que pareça, está em harmonia - e não em desacordo - com o princípio de prazer. $\mathrm{O}$ que seria este limite intrínseco do gozo senão efeito do próprio princípio de prazer incidindo sobre ele? O gozo fálico pode ser entendido, portanto, como um tipo de gozo que estaria não "para além”, mas intrinsecamente delimitado pelo princípio de prazer. Este seria o gozo que, segundo Lacan, acalma e tranquiliza.

O que podemos depreender daí é que o fato do gozo fálico ser intrinsecamente limitado, ao invés disso diminuir, aumentaria sua potência. Em uma interessante analogia com o futebol, utilizada por Vieira (2008), percebemos como o limite (regras) do jogo é o que torna o 'show de bola' do craque ainda mais arrebatador. Sigmund Freud, em um de seus textos mais sublimes, chamado "Sobre a transitoriedade" (1916[1915]/1996), escrito em novembro de 1915 (durante o segundo ano da Primeira Grande Guerra), já estabelecia os pilares sobre os quais Lacan construiria seu conceito de gozo fálico, ao afirmar que: "A limitação da possibilidade de uma fruição eleva o valor dessa fruição" (Freud, 1916[1915]/1996, p. 317). Está aí expressa claramente, nas palavras do gênio inventor da psicanálise, a potência do gozo fálico - o gozo limitado.

Aliás, a noção de usufruto, tão intimamente relacionada ao conceito lacaniano de gozo, mais especificamente de 'gozo fálico', nos remete também a essa mesma ideia de uma demarcação, uma delimitação do gozo. O usufruto é delimitado na medida em que não se pode consumir o bem em si; é como se só pudesse consumir os juros (o excedente) e não o principal. $\mathrm{O}$ principal, o patrimônio, deve ser preservado. Com a palavra, o mestre:

O usufruto quer dizer que podemos gozar de nossos meios, mas que não devemos enxovalhá-los. Quando temos usufruto de uma herança, podemos gozar dela, com a condição e não gastá-la demais. (Lacan, 1972-73/1985, p. 11) 
Para nos auxiliar no entendimento da importância da demarcação do gozo, recorreremos ao auxílio de duas analogias: da usina hidrelétrica e do barco à vela. Resumidamente, o funcionamento básico de uma usina hidrelétrica nos ensina sobre a importância da barragem (represa) para conter a água (energia em potencial) e torná-la útil. 'Barragem', inclusive, foi o termo utilizado por Valas (2001) na seguinte passagem sobre a questão do manejo do gozo na clínica: "Trata-se, pois, para liberar o sujeito, de fazer uma barragem para o gozo dos seus sintomas" (Valas, 2001, p. 63). Em relação à comparação com o barco à vela, a importância da delimitação pode ser observada na função das velas que, quando içadas, fazem barreira ao vento e impulsionam o barco, colocando-o em movimento. Note-se que içar velas e construir barragens não é fácil e costuma dar trabalho.

Lembremos que o 'amor pelo pai' é o que vai permitir a estruturação do supereu e, portanto, a introjeção da lei. "É o amor pelo pai que serve, de alguma forma, de regulação, ao desejo", diz Cottet (1989, p. 10). A função Nome-do-Pai é pacificadora para o sujeito, na medida em que, ao induzir a castração simbólica, põe limites ao gozo desenfreado, que, segundo Braunstein (2007), seria o "pior". O autor vai dizer ainda que o falo é o nome do significante que desvia o olhar do sujeito do gozo da Coisa (absoluto) para os objetos do desejo (roupagens do objeto a).

A mesma noção, dita de outra forma por Lacan, ficaria assim: "o amor é a sublimação do desejo" (1962-63/2005, p. 198). O desejo, por sua vez, é o que vai aparecer como limite ao gozo, principalmente, conforme vimos, sob a forma do amor. A proposição do amor como limite ao gozo fica ainda mais clara quando Lacan nos ensina que o amor é um fenômeno cultural e que "nem se cogitaria de amor se não houvesse a cultura" (Lacan, 1962-63/2005, p. 198).

Feita esta rápida introdução, ficamos em melhor posição para compreender o famoso aforismo lacaniano: "Só o amor permite ao gozo condescender ao desejo." (Lacan, 1963-63/2005, p. 197). Fazer com que o gozo condescenda ao desejo é, segundo Braunstein (2007, p. 290), “função do amor". Podemos inferir a partir daí que haveria uma espécie de 'báscula' entre o amor-sublimação e gozo e também, logicamente, entre gozo e desejo. Dentro desta concepção, o desejo 
apresenta-se, portanto, como uma defesa, na medida em que ali onde ele cai, erige-se o gozo. "Pois a natureza última do desejo é, como sabemos, a de uma barreira posta ao gozo" (Braunstein, 2007, p. 291).

Como se o amor protegesse o sujeito do gozo do Outro e, portanto, de seu próprio gozo. Proteção (proibição) contra ir além de um certo limite no gozo. Para ilustrar esta noção psicanalítica, recordamos do seguinte acontecimento, vastamente noticiado pelos meios de comunicação na ocasião, envolvendo um dos maiores craques da história do futebol. De que ordem é a força presente no apelo de uma filha capaz de mudar um destino que parecia selado?

Em maio, (Maradona) é novamente internado, chegando a ser recusado por várias instituições médicas da Argentina e do exterior. Chega a ser sedado e amarrado após uma crise de abstinência da cocaína. Seu médico particular declara em ultimato que ele tem a última chance de salvar sua vida. Maradona posteriormente afirmaria que retirou forças para se desintoxicar definitivamente após apelos de sua filha Giannina: 'pai, você tem que viver por mim'. (Wikipedia http://pt.wikipedia.org/wiki/Diego_Maradona)

Outro bom exemplo, noticiado recentemente, conjuga corpo e amor funcionando como limites poderosos ao gozo. Neste breve e esclarecedor depoimento, uma celebrada figura da sociedade carioca conta como conseguiu parar, de uma só vez, com o uso abusivo de duas drogas poderosas, o álcool e o cigarro:

Comecei bebendo para relaxar. Aos poucos, passei a beber sem limites. Ficava envergonhado, não era esse o exemplo que eu queria dar para as minhas filhas. $\mathrm{O}$ problema do pulmão funcionou como um sinal de alerta. Parei com o álcool e com os cigarros ao mesmo tempo. (Jornal O Globo, publicado em 04/11/12)

Vemos aí presente, em tão poucas palavras, a mescla de 'amor' e 'corpo' funcionando como efetivas barreiras ao gozo. A propósito, o corpo é uma das mais eficientes e radicais barreiras no caminho do gozo. No limite, o limite último do gozo é corporal. Ou seja, quando todas as demais barreiras foram ultrapassadas, o que faz um adicto parar de cheirar cocaína ou fumar crack é o corpo, através, por exemplo, de uma parada cardio-respiratória. Quando os limites psíquicos não funcionam, ou não são suficientes, é o corpo, em última instância, 
que vai ficar encarregado de parar o sujeito; nem que seja com sua morte. Sendo o gozo "corporal”, se o corpo para, então o gozo necessariamente cessa.

Antes que o corpo, este último e radical recurso para deter o gozo, precise entrar em cena, a psicanálise aposta na linguagem como pacificadora e estabilizadora da perturbação corporal causada pelo gozo. A psicanálise - 'talking cure' em sua essência - se apresenta, desde sempre, como um tratamento pela linguagem e aposta nela como um anteparo de proteção contra o gozo e a angústia. Se há palavras a serem ditas, então não se trata de gozo ('J'ouis' = 'eu escuto', não 'eu falo'). Prazer, portanto, seria encontrar um nome que falasse do gozo, para prevenir o sujeito de ser invadido pelo gozo. A palavra faz contenção ao gozo ou, melhor dizendo, a palavra mata a Coisa, como já enunciavam Kojève e Lacan. Pode-se dizer que o gozo é invasivo, a não ser que se saiba 'conversar com ele'.

O desejo movimenta a cadeia de significantes, distanciando corpo e gozo. Cito Braunstein: "a linguagem é o que funciona como barreira a um gozo que não existiria sem ela” (2007, p. 77), ou seja, a palavra limita o gozo. Mesmíssima relação mantém o gozo com a lei, que em última instância é a própria lei da linguagem. A lei do desejo, ou seja, a própria interdição do incesto, é, de acordo com Valas (2001), da mesma natureza que essas leis da linguagem. O gozo precisa da lei para transgredir. Sem lei, não há gozo.

Outra importante barreira no caminho do gozo é a fantasia neurótica, com sua matriz psíquica simbólico-imaginária. A fantasia neurótica pode ser pensada como a realização distorcida do desejo, uma resposta ao enigmático desejo do Outro, com o propósito de anulá-lo, distanciando o sujeito tanto do desejo quanto do gozo. Paradoxalmente, a fantasia é tanto o que permite que o sujeito sustente seu desejo, como aquilo que, ao mesmo tempo, o afasta de seu desejo. 


\section{Gozo, angústia e desejo na cultura}

"Ao infinito... e além!"

(Buzz Lightyear - Disney - Pixar)

Temos observado na atualidade um tipo de exigência de satisfação irrestrita, que reflete bem a tônica da nossa chamada 'sociedade do consumo' contemporânea, ou 'sociedade do excesso', ou ainda - por que não? -, 'sociedade do gozo'. O 'supérfluo', o 'descartável', o 'excesso' e o 'ilimitado' são marcas características da nossa cultura. Ipod, Ipad e Iphones 1, 2, 3, 4 e 5 ilustram bem o que queremos dizer. Por falar nesses aparelhinhos mágicos, a 'Apple', segunda marca mais valiosa do mundo, segundo a consultoria Interband (relatório "100 Melhores Marcas Globais", de 02/10/12), condensou, brilhantemente, em sua logomarca da maçã mordida, a ideia de gozo. Ouso dizer que numa hipotética competição para se criar um ícone que representasse o conceito lacaniano de gozo, a logomarca da 'Apple' seria fortíssima candidata. Ao escolher o fruto do pecado ou fruto proibido, representado por uma despretensiosa maçã mordida - note-se que a maçã poderia estar inteira, mas está mordida - a potência norte-americana da tecnologia transmite, subliminarmente, aos seus consumidores, as principais ideias contidas no conceito lacaniano de gozo, quais sejam: transgressão, excesso, sem-limite, e, principalmente, a ideia de consumação/realização do desejo. A maçã apresentada em sua versão 'inteira' poderia ser associada à ideia de desejo, enquanto que em sua apresentação mordida remeteria ao gozo. Se o fruto proibido está mordido, então vá em frente, meu caro consumidor! Transgrida! Compre! Faça fila! Se não puder adquirir à vista, então parcele! O que não pode é ficar sem Ipad, Iphone e Ipod...

O equivalente deste fenômeno cultural tão atual, pensado a partir da teoria e da clínica psicanalíticas, nos remete ao conceito de 'gozo', teorizado pelo psicanalista francês Jacques Lacan a partir, pasmem, do final da década de 50 . Sobre estes objetos tão atraentes que "pululam", por exemplo, nas suntuosas vitrines dos 'shoppings centers', prometendo felicidade e completude, Miller 
(2012) vai dizer, com Lacan, que, na verdade, quando muito, proporcionam "bocadinhos de gozo", e olhe lá! Acompanhemos Miller (2012):

É o que Lacan chama de miúdos objetos pequeno $a$, o que pulula na sociedade para causar nosso desejo e tamponar a falta de gozo, mas apenas por um instante, pois a repetição não se detém. Tudo o que nos é permitido gozar, o é por pedacinhos. É isto que Lacan chama - com uma expressão que capta bem o de que se trata - de "bocadinho" do gozo. Vemos nosso mundo cultural se inundar dos substitutos do gozo que são os nadicas de nada. São esses bocadinhos do gozo que conferem seu estilo próprio ao nosso modo de vida e ao nosso modo-de-gozar. (Miller, 2012, P. 36)

'Goza!' ('Jouis!) Sim, segundo Lacan, é isso o que ouvimos ('J'ouis'), tanto externamente (voz da cultura) quanto internamente (voz do supereu). Tirando proveito da homofonia existente entre as expressões francesas 'Jouis!' (Goza!) e 'J'ouis' (Ouço), Lacan afirma o seguinte: “A esse Goza [Jouis], só posso responder uma coisa: é Eu ouço [J'ouis], mas, naturalmente, nem por isso gozo com mais facilidade" (1962-63/2005, p. 92). Externamente, este 'mandamento' nos é veiculado, por exemplo, pelas mensagens publicitárias, enquanto que, internamente, as vozes do supereu - amplificadas pelo isso - deixam o eu praticamente sem alternativas, a não ser obedecer. Besset (2002), ao levantar a questão sobre novos tempos para a angústia, refere-se à atualidade da seguinte maneira: "em vez da repressão da era vitoriana, vivemos num tempo onde reina a pulsão, sob o imperativo categórico de gozo do supereu” (Besset, 2002, p. 15).

Não amanhã, não daqui a pouco, não parcialmente, mas sim aqui, agora e integralmente, até o limite (ou além). O que importa é o prazer imediato e ilimitado, sem contenção e sem barreira. O que se busca é 'gozar a qualquer preço' (Melman, 2003). Vemos na atualidade um tipo de sofrimento causado não mais pela falta, mas sim pelo excesso, pela "falta de falta", como já enunciava Lacan. O dito Imperativo do Gozo, com seu mandamento “Goza!”, ordenado pelo supereu, em conluio com o isso, deixando o eu praticamente sem alternativas, pode ser visto como a própria expressão do excesso. É como se o gozo, que inicialmente seria da ordem de uma 'transgressão', passasse a representar uma 'obrigação' para o sujeito. Gozar sob ordens, nada mais angustiante do que isso. 
Como se a mesma lei que antes proibia passasse, caprichosamente, a incitar o gozo. Eis o paradoxo.

Multiplicam-se nos consultórios sujeitos acossados por sintomas decorrentes de uma exigência de satisfação irrestrita, que reflete a tônica da sociedade hedonista contemporânea. 'Por que resistir às tentações?', pergunta um cartaz afixado em um restaurante a quilo no centro da cidade; 'Pecado é tentar resistir...' afirma uma faixa na entrada de uma loja de doces. Ou seja, 'Goza!'. O bombardeio de mensagens publicitárias do tipo "No limits" (Hollywood), "Impossible is nothing" (Adidas) e "Fale e navegue ilimitado" (Oi), dão a tônica da sociedade contemporânea. Parece que empresários e publicitários andaram lendo Freud, tamanha a eficiência das suas mensagens direcionadas cada vez mais à ideia do 'ilimitado'. Segundo escrevia o criador da psicanálise, já no início da década de 30 (1930[1929], p.87), o sentimento de felicidade oriundo de uma pulsão não domada pelo eu é 'incomparavelmente mais intenso' do que o derivado da satisfação de uma pulsão que já foi domada. Está aí, portanto, a explicação psicanalítica para a forte atração exercida em nós pela ideia do 'ilimitado'. As empresas, juntamente com suas agências de propaganda, vêm claramente apostando suas fichas cada vez mais nisso. Escutemos Freud: "uma satisfação irrestrita de todas as necessidades apresenta-se-nos como o método mais tentador de conduzir nossas vidas" (1930[1929]/1996, p. 85).

Logo em seguida, porém, no mesmo texto, Freud faz a seguinte advertência, a qual, definitivamente, não interessa nem um pouco aos publicitários e nem à indústria: "isso, porém, significa colocar o gozo antes da cautela, acarretando logo o seu próprio castigo" (1930[1929]/1996, p. 85).

'Fique linda, feliz e... magra!', ordena (sim, é uma ordem!) um cartaz pendurado em uma banca de jornal de frente para uma movimentada avenida. Trata-se do anúncio de uma revista feminina, cujo título é, não por acaso, 'Máxima'. A mensagem parece bem clara: tudo máximo! Prazer máximo! Felicidade máxima! Beleza máxima! Corpo máximo! Emprego máximo! Marido e mulher máximos! Sexo máximo! Dinheiro máximo! Filhos máximos! E se nem tudo em nossas vidas for assim, tão máximo? Então você é um fracassado, um 'loser'. A mensagem é clara: 'Não aceite o menos', 'Busque sempre mais', 'Just 
do it', 'vá além'. A propósito, 'Ao infinito... e além!' é o mantra repetido por 'Buzz Lightyear' - um dos super-heróis preferidos da garotada de hoje em dia. $\mathrm{Ou}$ seja, Goza! Sim, o conceito psicanalítico de gozo está intimamente ligado a este excesso, a esta transgressão. Um excesso que por um lado é prazeroso, mas por outro, é causa de dor, de angústia e de sofrimento.

É claro que o recalque não acabou! Não tenhamos dúvida disso... e, enquanto formos seres falantes, não vai acabar nunca. Mas é inegável o fato de que há na atualidade uma força cultural que impele os sujeitos ao ilimitado do gozo, fazendo com que o recalque esteja 'em baixa' hoje em dia.

Uma intrigante questão se apresenta tornando o quadro ainda mais complexo: como dar conta deste excesso, deste 'tudo ao mesmo tempo agora' com cada vez menos tempo e recursos de simbolização disponíveis? O fenômeno da internet, junto com todas suas maravilhas, trouxe a reboque a escassez de palavras. As abreviações tomaram conta da rede mundial: 'risos', transformaramse em 'rs', 'beijos' viraram 'bjs', 'abs' ao invés de 'abraços'... e no Twitter são, no máximo, 140 caracteres por mensagem, não se esqueçam! Isso angustia. A escassez de palavras, o empobrecimento da linguagem angustia. $\mathrm{O}$ distanciamento entre as pessoas, a falta de laço social, também angustia: 500 amigos no Facebook e ninguém ao lado para conversar. Captando bem esse fenômeno que chamou de "individualismo contemporâneo", e articulando-o ao conceito de gozo, Miller (2012) escreve o seguinte:

O ponto de partida encontrado no gozo é o verdadeiro fundamento do que aparece como a extensão, ou mesmo a demência, do individualismo contemporâneo. (Miller, 2012, p. 44)

Na sociedade do gozo observamos um 'esvaziamento do desejo', na medida em que todo desejo - toda falta - é cada vez mais facilmente, rapidamente e descartavelmente preenchível hoje em dia. Há um fortalecimento da excitação, do gozo, e, por outro lado, cada vez menos recursos (linguísticos) para lidar com isso. É como se hoje em dia o gozo estivesse levando vantagem sobre o prazer. A exibição do gozo é uma das marcas da contemporaneidade. A lei do desejo está sendo vencida pelo imperativo do gozo. O triunfo do gozo sobre o prazer: 
podemos inferir que está aí uma das possíveis razões por trás do estrondoso sucesso do romance erótico "Cinquenta tons de cinza", também conhecido como "o pornô das mamães". Com mais de 10 milhões de livros vendidos nas seis primeiras semanas do lançamento, a narrativa descreve, em ricos detalhes, as aventuras eróticas de uma jovem estudante de 21 anos, com um magnata sedutor mais velho. Como se não bastasse para cativar os leitores, dois ingredientes picantes especiais são adicionados neste relacionamento: ela é virgem e ele adepto de práticas sadomasoquistas. Tendo êxito em mesclar, tão bem, a inocência da moça virgem com a perversão do rapaz sadomasoquista, a autora consegue exercer um verdadeiro fascínio em seus leitores, principalmente, leitoras. Sem nos estender muito nesta questão, que não é foco deste trabalho, uma das explicações possíveis para a predominância das mulheres dentre os leitores deste romance, em nossa opinião, diz respeito mais a certas características do feminino que as levam a preferir algo mais sutil e discreto quando o assunto é pornografia, do que qualquer outra coisa.

O empuxo ao gozo, ao excesso e ao ilimitado na atualidade é forte, e cada um se vira como pode. Parecendo captar bem este fenômeno cultural, a autora do best-seller aborda, com linguagem simples e acessível, um relacionamento recheado de práticas sadomasoquistas, conduzindo seus leitores, de forma sutil, quase imperceptível, ao fascinante campo do gozo, do proibido e da transgressão. Isso, sem dúvida, exerce forte atração, principalmente naquelas mulheres acostumadas com a rotina, com o prazer limitado, com o 'socialmente aceito' e o 'politicamente correto'. Mais de vinte orgasmos em apenas três semanas é o que experimenta a jovem protagonista do livro. Esta é a contabilidade do gozo em 'Cinquenta tons de cinza'. Quem não se interessaria?

Esta marca do excesso na atualidade torna-se bem visível quando observamos a busca alucinada dos sujeitos por aquilo que Birman (2000) chama de poção mágica, que impeça o reconhecimento da falta - mola do desejo, diga-se de passagem -, da incompletude, do sofrimento. Eis uma das características mais marcantes da atualidade. Alimentada diariamente pela nossa própria cultura, esta busca nos remete a um 'não querer saber da falta', que representaria para o sujeito 
uma certa dificuldade em estabelecer limites, constatar desilusões e lidar com a lei. Nas palavras do autor temos o seguinte:

Com efeito, nessa versão da atualidade, o que orienta o indivíduo é a busca desesperada de uma poção mágica que impossibilite o reconhecimento do sofrimento inerente à existência, impedindo então a constatação das desilusões que a vida inevitavelmente provoca em qualquer ser humano, de forma que o sujeito possa existir em estado nirvânico. (Birman, 2000, p. 202)

Objetos que ofereçam ou prometam (quase todos prometem) a tão desejada sensação de completude, ou alívio imediato dos sintomas e do sofrimento, são cada vez mais desejados e consumidos. Onde há demanda, há oferta. Temos que reconhecer a incrível habilidade e competência da nossa cultura em desenvolver e ofertar tais objetos. Fazendo um rápido parêntese, é como se o gozo estivesse para o consumo e o desejo para a produção. Sobre a oferta de tais objetos, Vieira (2008) diz o seguinte:

Afinal, hoje não há objeto que nosso capitalismo tardio não tenha ou não possa prover. Nada se furta a ele. Os índios? Eles têm celular. Os monges tibetanos? Vendem best-sellers. (Vieira, 2008, p. 32)

\subsection{Drogas}

O mais grosseiro, embora também o mais eficaz, desses métodos de influência (para evitar o sofrimento) é o químico: a intoxicação. (Freud, 1930[1929]/1996, p. 86)

Dentre os mecanismos utilizados pelo homem para evitar o sofrimento e o mal-estar, a intoxicação é, segundo Freud, um dos mais poderosos. De acordo com Braunstein (2007), um dos principais atrativos da droga seria esta operação na qual o Outro é substituído por esse objeto (droga) "sem desejos nem caprichos", que não trai e cujo único problema é ter de procurá-lo.

Em "O Mal Estar na Civilização" (1930), quando nos fala sobre a intoxicação, Freud destaca suas virtudes e eficácia na busca pela felicidade e no 
afastamento da angústia. Não à toa, refere-se aos veículos intoxicantes, como verdadeiros "amortecedores de preocupações". Acompanhemos Freud (1930[1929]/1996):

com o auxílio desse 'amortecedor de preocupações', é possível, em qualquer ocasião, afastar-se da pressão da realidade e encontrar refúgio num mundo próprio, com melhores condições de sensibilidade. (Freud, 1930[1929]/1996, p. 86)

Um pouco mais adiante, porém, no mesmo texto, Freud pondera a questão e não deixa de fazer algumas advertências, que nos remetem a uma das características do conceito lacaniano de gozo, o desperdício de energia:

é exatamente essa propriedade dos intoxicantes que determina o seu perigo e a sua capacidade de causar danos. São responsáveis (...) pelo desperdício de uma grande quota de energia que poderia ser empregada para o aperfeiçoamento do destino humano. (Freud, 1930[1929]/1996, p. 86)

Falemos das drogas, tanto as legais quanto as ilegais. O uso abusivo destas "poções mágicas", conhecidas pelos nomes de antidepressivo, estabilizador de humor, pílula azul, álcool, maconha, cocaína, crack, dentre outras, espalha-se assustadoramente, das classes mais abastadas aos moradores de rua. No início de 2010, um relatório divulgado pelo INCB (International Narcotics Control Board), organização ligada à ONU, trouxe uma informação surpreendente: o uso abusivo dos chamados 'medicamentos controlados', que só podem ser vendidos com receita médica, cresceu tão rapidamente no mundo que o número de viciados nestes medicamentos superou o número de usuários de cocaína, heroína e ecstasy juntos. A respeito desta grande variedade de drogas permitidas, Braunstein (2007) aponta outro paradoxo no fato destas serem postas à disposição do sujeito justamente por aquele de quem esse mesmo sujeito pretende se separar: o grande Outro. Indicando que o surgimento da angústia estaria relacionado não à falta, mas a essa avalanche de objetos, Miller (2007) diz o seguinte: 
Freud señala que la angustia se liga a la perdida del objeto, mientras que para Lacan esta surge cuando la falta falta, es decir, cuando hay objeto y cuando hay muchos objetos. ${ }^{20}$ (2007, p. 94)

Vivemos em uma sociedade onde a perda e a falta são inaceitáveis, busca-se a completude o tempo todo. O sujeito está sempre em busca de novos objetos, na esperança de que estes proporcionem, finalmente, uma satisfação plena, que nunca é alcançada. Sobre essa busca desenfreada pela completude na atualidade, Braunstein (2007, p. 100) diz o seguinte: "a completude nada mais é do que um fantasma do neurótico neste tempo espantosamente atormentado por exigências idílicas". Este 'não querer saber da falta', esta busca inconsequente e desesperada pela completude, por aquilo que vai 'tapar o buraco', é causa de sofrimento. "A gente não quer só dinheiro; A gente quer inteiro e não pela metade" (Comida Titãs), reivindica a letra de um dos maiores sucessos do rock nacional das últimas décadas. Adquirem-se novos objetos, na esperança de que estes finalmente deem conta da falta, do buraco, do vazio angustiante, e que possam proporcionar uma satisfação plena, completa, definitiva e ilusória.

Em nossa cultura, valoriza-se somente o 'winner': o 'loser' não tem vez, não tem voz. Será que não precisaríamos reconhecer e conviver com a falta e a incompletude, ao invés de mascará-las? Não seria o caso de darmos mais valor àquilo que nos resta? Acolher nossa imperfeição? Imperfeição esta, vale frisar, que nos torna únicos. Sempre faltará algo, há que se reconhecer isto, nem que sejam palavras...

Psicanaliticamente falando, e quem afirmava isto era Freud, o sentimento de felicidade, oriundo de uma pulsão não domada pelo ego, é incomparavelmente mais intenso do que o derivado da satisfação de uma pulsão que já foi domada.

Ocorre que, invariavelmente, paga-se um preço para gozar; e este preço, pode ser pago de diversas maneiras, principalmente, com dinheiro, saúde e, não raro, com a própria vida. Trechos de notícias veiculadas na internet sobre as mortes de uma estudante, de 20 anos, em um cruzeiro universitário, em 2008, e de

\footnotetext{
${ }^{20}$ Freud diz que a angústia está ligada à perda do objeto, enquanto que para Lacan esta surge quando a falta falta, ou seja, quando há objeto e quando há muitos objetos.
} 
um jovem americano, de 24, encontrado morto em um apartamento em Copacabana, em 2010, têm mais coisas em comum do que os vestígios de vômito encontrados nas duas cenas. Servem para ilustrar e trazer a teoria para o dia-a-dia. A marca do excesso, nua e crua:

(2008) "Amostras de sangue do corpo da estudante de 20 anos, que morreu a bordo de um cruzeiro universitário, foram levadas para serem analisadas pelo Instituto Médico-Legal" / "Afirmaram que houve consumo de drogas durante a viagem" / "O delegado da Polícia Federal, no entanto, não descarta a possibilidade de que a passageira tenha morrido por ingestão conjunta de álcool e drogas" / "A estudante morreu em consequência de asfixia por aspiração de líquido - vômito segundo o laudo do IML".

(2010) "De acordo com os PMs, ao lado do corpo do americano, de 24 anos, havia cachimbos para fumar crack, remédios, bebidas e muitos comprimidos de estímulo sexual" / "o jovem era sempre visto entrando com mulheres diferentes" / "Embaixo do corpo do rapaz, havia também vestígios de vômito".

O gozo da droga "mascara ou substitui o desejo inconsciente (...). Trata-se de uma necessidade colocada em termos absolutos, de vida ou morte: ou há o gozo químico ou há o nada" (Braunstein, 2007, p. 281). Um interessante paradoxo pode ser apreendido a partir da relação desmedida que, às vezes, se estabelece entre o sujeito e determinados objetos. Substâncias e produtos adquiridos e consumidos para se "viver melhor" acabam afetando a continuidade da própria vida, induzindo o sujeito a percorrer um trajeto inverso ao esperado, causando desprazer e, em muitos casos, provocando a morte.

\subsection{Lei e limite}

Atento a este movimento cultural de empuxo ao gozo, Vieira (2008) discute da seguinte maneira a complexa questão da interdição do gozo, demonstrando como este, sendo fundamentalmente transgressivo, escapa às tentativas externas de limitação: 
Mas de onde virá, nos dias de hoje, uma autoridade que seja levada a sério em seu "basta!", em seu "é preciso dar limites?" Não é suficiente engrossar o coro dos homens de bem para impor restrições ao gozo. (...) Sempre se pode fechar a boate, mas a festa se prolonga em bares, calçadas, na casa de alguém, e assim por diante. Temos que dar ênfase mais ao gozo e a seus mecanismos intrínsecos de regulação do que às instâncias de interdição.” (Vieira, 2008, p. 90)

Quando se fala de lei e limite em psicanálise, fala-se de pai, ou melhor, de função paterna. Não tão badalado quanto o pai do Édipo (representante da lei), há também outro pai na obra freudiana, qual seja, o pai da horda primeva (tirano), apresentado por Freud em seu trabalho antropo-psicológico chamado "Totem e Tabu" (1913). Este pai primitivo seria percebido pelos demais membros da horda como sendo um fora-da-lei, uma figura de poder absoluto, que agrega em torno de si todas as mulheres e riqueza da horda, privando destas benesses seus próprios filhos e rivais que, enfurecidos, um belo dia se reúnem para assassiná-lo. Instaurase desta maneira, neste ato "de valor inaugural e fundador" (Rudge, 1998, p. 118), a própria cultura. Nas palavras de Rudge (1998) temos o que segue:

A horda primitiva, mito que Freud busca em Darwin para construir as origens da cultura, era submetida ao poder de um pai tirânico que fazia de sua vontade a lei. Esse pai, violento e ciumento, guardava para si todas as mulheres, expulsando os filhos quando cresciam. Os filhos expulsos, um dia, motivados por seu ódio, reuniram-se juntando as suas forças e conseguiram assim assassinar e devorar o pai despótico, dando um fim nessa horda patriarcal. (...) A refeição totêmica é uma comemoração desse ato criminoso e memorável que marca o advento da organização social, das restrições morais e das religiões. (Rudge, 1998, p. 118-119)

Portanto, segundo a autora, o parricídio (transgressão) é condição sine qua non para o advento da cultura, uma vez que a culpa originada a partir deste ato é o que introduzirá o pacto social, através da renúncia aos desejos e as restrições morais. Estamos, mais uma vez, diante de um intrigante paradoxo no qual a transgressão da lei (assassinato do pai) vai reforçar a própria lei (pacto social). A civilização tem por objetivo moderar, limitar essa vontade de gozo e o consegue, sem dúvida, pela formação de ideais. Por outro lado, o fenômeno atual chamado pelos psicanalistas de declínio da imago paterna não diminuiria a tirania do supereu e seu imperativo de gozo, pelo contrário, incitaria, segundo Freitas \& 
Rudge (2011), a busca incessante pela satisfação absoluta. Acompanhemos as autoras:

(...) efeitos decorrentes do declínio da imago paterna, que não diminuem a pressão do supereu. Pelo contrário, isto permite o surgimento de figuras fantasmáticas de autoridade que favorecem a vivência de devastação pelo que implicam de submissão ao Outro, senhor do gozo, que incita à busca incessante de satisfação absoluta. (Freitas \& Rudge, 2011, p. 261)

\subsection{O Pai gozador}

O pai de Totem e Tabu, ao contrário do pai do Édipo, não estaria subordinado ele próprio à lei. Qual lei? A lei que proíbe o acesso de seus filhos às mulheres da horda. Parece então que nos aproximamos do que possivelmente seria a pergunta-chave por trás deste "empuxo ao gozo" que observamos na atualidade: se aquele que representa a lei também goza, por que eu devo interromper o meu gozo? Sobre a relação peculiar que se estabelece entre o sujeito e a droga, Braunstein (2007) diz o seguinte:

Supõe-se que sua adicção lhe permitiria uma via de acesso privilegiada e direta, em curto-circuito, até o gozo e que seria um modo de contestar a exigência do Outro e da cultura de renunciar ao gozo. (Braunstein, 2007, p. 280)

É como se o pai tirano-mítico da horda primeva tivesse retornado do além, vindo assombrar-nos e instigar-nos, em pleno século XXI, a partir de várias direções. Senão vejamos algumas delas: o partido político que tinha como principal bandeira o combate à corrupção, quando assume o poder implanta o maior esquema de desvio de dinheiro público, nunca antes visto na história deste país. Recentemente, o ex-"xerife" de ordem pública do Estado do Rio de Janeiro, atual deputado federal, foi parado em uma blitz da Operação Lei Seca e, além de estar sem sua carteira de habilitação, recusou-se a fazer o teste do bafômetro. Poucos meses antes, outro episódio vastamente noticiado, nos remete à figura desse pai-tirano-que-tudo-pode: o ex-coordenador da mesma Operação Lei Seca, dirigindo em ziguezague, atropelou quatro pessoas, matou uma e fugiu do local do 
crime, sem prestar socorro. Repito, ex-co-or-de-na-dor da Operação Lei Seca. Ainda mais recentemente - notem que os exemplos pululam - o prefeito recémeleito de um pobre município fluminense, em um de seus primeiros atos no poder, se auto-concedeu, com o aval da câmara de vereadores, um generoso aumento salarial de mais de cem por cento (102\% mais precisamente). Os exemplos multiplicam-se, nas mais diversas áreas da nossa cultura, mas creio que já são suficientes para percebermos que o pai de Totem e Tabu (1912-13) não está morto; ele de alguma forma ressuscitou e tem nos dado notícias frequentes, 'ao vivo e a cores', na tela da televisão, do computador e na capa dos principais jornais... E parece que voltou sedento de gozo, querendo usufruir novamente - a todo custo, e com exclusividade -, de TODAS as mulheres da horda. Onde foram parar nossas referências? Se todos gozam, porque eu, logo eu, devo interromper meu gozo? É a pergunta que não quer calar, tanto nas ruas como nos consultórios de psicanálise. Passo a citar Vieira (2008) em sua análise crítica da atualidade e seu 'empuxo ao gozo':

Hoje, goza-se mais do que ontem? Sabe-se lá. Por certo, a intimação ao prazer agita e perturba. Institui uma espécie de bloco dos "aflitos do gozo", que extrapola os sambas de carnaval e parece ter vindo para ficar. Estamos quase no avesso do tempo freudiano. Testemunhamos a tônica da satisfação ao passo que, no início do século XX abordava-se o prazer valendo-se, sobretudo, da falta e da interdição. (Vieira, 2008, p. 89)

É como se hoje estivéssemos vivendo sob a primazia do pai da horda primitiva ("pai gozador", fora-da-lei) e não mais sob a égide do pai do complexo de Édipo (representante-da-lei). Um bom exemplo deste nosso ponto de vista são as manifestações populares, recentemente ocorridas no Oriente Médio e Norte da África, que ficaram conhecidas como "Primavera Árabe". A semelhança de tais episódios com o mito freudiano de Totem e Tabu (1912-13), no qual os filhos se reúnem para assassinar o pai-tirano, é inegável.

Há uma espécie de decadência do gozo fálico (intrinsecamente regulado) na atualidade e um outro gozo em ascensão. Poderíamos nos perguntar: isso é bom ou ruim? Melhor ou pior? Em minha opinião, nem melhor, nem pior, apenas diferente. E de maneira diferente também precisa ser pensada a clínica. 


\section{Gozo, angústia e desejo na clínica}

Chegado a este ponto o sujeito se vê forçado a ir além de seu fantasma, das satisfações gozosas a que poderia prestar-se a situação analítica; é levado a se identificar com a causa de seu desejo, com sua falta. (Braunstein, 2007, p. 293)

\subsection{Desejo na clínica}

A pré-condição para uma ética da psicanálise passa por um mandamento prescrito por Lacan da seguinte forma: 'La única cosa de la que se puede ser culpable es de haber cedido em su deseo. ${ }^{21}$ (1959-60/2009, p. 382). Tal proposição é, com efeito, um repúdio radical a certo ideal do bem; uma não aceitação das normas sociais, meramente consensuais e fantasmáticas, em favor de uma afirmação fundamental cujo valor não pode necessariamente ser provado ou comunicado.

O percurso de uma análise implica em propiciar ao analisando o reconhecimento da verdade sobre seu desejo (inconsciente). Entretanto, o reconhecimento do desejo só é possível no domínio simbólico da linguagem, quando este é articulado na fala. Diz Lacan: "É somente quando ele se formula, se nomeia diante do outro, que o desejo, seja ele qual for, é reconhecido no sentido pleno do termo" (1953-54/2009, p. 242). O que seria importante, segundo Lacan é "ensinar o sujeito a nomear, a articular, a fazer passar para a existência, este desejo que está, literalmente, para aquém da existência, e por isto insiste. (...). Que o sujeito chegue a reconhecer e a nomear seu desejo, eis aí a ação eficaz da análise." (1954-55/2010, p. 309). Articulando o desejo na fala, o analisando pode trazê-lo à existência; ao nomeá-lo o sujeito cria, produz uma nova maneira de ser e estar no mundo.

Entretanto, existe certo limite, certa incompatibilidade nesta articulação entre desejo e fala, e é exatamente esta incompatibilidade que pode explicar a chamada irredutibilidade do inconsciente, uma vez que o inconsciente não é o que

${ }^{21} \mathrm{~A}$ única coisa da qual se pode ser culpado é de haver cedido em seu desejo. 
não é conhecido, mas o que não pode ser sabido. Apesar da verdade sobre o desejo estar presente, em certo grau, em todo discurso, a fala é incapaz de articular toda a verdade sobre o desejo. Toda vez que se tenta articular o desejo na fala há sempre um resto, um excesso da ordem do inefável; resto este, diga-se de passagem, que pode ser considerado fundamental, na medida em que representa, nada mais nada menos, que a garantia da continuidade do sujeito enquanto ser desejante.

Uma vez que a 'talking cure' ocupa-se de transformar representações inconscientes em conscientes, pergunta-se: como representar o irrepresentável? Como falar do vazio? Como dizer o indizível? De que maneira pode-se lidar, na clínica, com aquilo que é impossível nomear e representar? Apesar da importância central da palavra na clínica psicanalítica, há que se pensar em outras e novas possibilidades de manejo clínico para lidar com o inefável, com aquilo que é impossível simbolizar. Vieira (2008) aponta uma direção:

A psicanálise convoca nossos outros para nos ajudarem a fazer diferente com esse insustentável desamparo. (...) O essencial é que encontremos com eles algo que soletre, de lado, meio ilegível, como deve ser o monstro de cada um (Vieira, 2008, p. 43).

A questão de como o analista deve lidar com as demandas do analisando é outro aspecto crucial de uma análise. Certamente, o analista não deve buscar atender às demandas do analisando, muito menos se trata simplesmente de frustrálas todas. Se por um lado, a satisfação da demanda pode eclipsar o desejo, a frustração pura e simples, não deve ser vista como um fim em si mesma, mas como forma de impelir o analisando a trabalhar e efetuar mudanças. A frustração na clínica permite também que os significantes a ela atrelados possam emergir no tratamento. Vejamos como Lacan (1960-61/1992) aborda a questão:

A ambivalência primeira, própria a toda demanda, é que, em toda demanda, é igualmente implicado que o sujeito não quer que ela seja satisfeita. O sujeito visa em si a salvaguarda do desejo (...). (Lacan, 1960-61/1992, p. 202)

\section{- Desejo do Analista}


Além de atribuir um saber ao analista ('sujeito-suposto-saber'), o analisando também lhe atribui um desejo, chamado por Lacan de 'desejo do analista'. Uma das principais tarefas do analista, ao longo de uma análise, seria a de tornar impossível ao analisando ter alguma certeza sobre aquilo que ele, analista, espera dele. De acordo com Lacan (1964/2008), o analista deve assegurar-se, portanto, que seu desejo se mantenha uma incógnita para o analisando. Desta forma, o suposto-desejo do analista torna-se uma força motriz do processo analítico, uma vez que mantém o analisando trabalhando, tratando de descobrir o que o analista espera dele. Ao apresentar ao analisando o enigma do seu desejo, o analista ocupa assim o lugar do Outro, a quem o sujeito dirige a pergunta 'Che vuoi?' ('O que queres de mim?'), fazendo emergir a fantasia fundamental na transferência. Este é um dos sentidos que podemos depreender desse desejo que, segundo Lacan, seria próprio do analista.

A outra leitura possível da expressão lacaniana 'desejo do analista', diz respeito ao desejo que deve impulsionar o analista no percurso de uma análise; um desejo que seria próprio do analista. Certamente, este não seria um desejo de 'fazer um bem' ou 'curar' o analisando, mas, ao contrário, trata-se, segundo Lacan (1959-60/2009) de um 'não-desejo de curar'. Este desejo também não seria o de que o analisando se identifique com o analista, longe disso. Lacan defende a ideia de que o desejo do analista deveria inclinar-se em uma direção oposta a da identificação (1964/2008). Ao invés da identificação, o analista deveria desejar que a verdade singular do analisando emerja; uma verdade absolutamente diferente da sua. Daí a ideia lacaniana de que o desejo do analista seria um desejo de obter a diferença absoluta.

\section{- Desejo nas estruturas}


Sobre a forma como o desejo se situa em relação às estruturas, Lacan (196061/1992) explica que na histeria temos o estatuto do desejo enquanto desejo insatisfeito, enquanto que na obsessão teríamos algo da ordem de um desejo impossível. Apoiando-nos no Complexo de Édipo freudiano, uma das formas de pensar esta proposição lacaniana seria através da articulação disso que Lacan nomeia de 'desejo impossível' com o desejo incestuoso (sexual e inconsciente) do filho pela mãe, enquanto que, o 'desejo insatisfeito' da histérica estaria relacionado à insatisfação da menina por não ter seus desejos (sexuais e inconscientes) em relação ao pai atendidos. A diferença entre o "impossível" e o "insatisfeito" adviria, precisamente, a partir da castração.

Na passagem a seguir, Freud (1913/1996) discorre sobre as formas que o desejo pode assumir nas estruturas, aproximando "de uma só vez, num resumo notável, as três grandes neuropsicoses" (Lacan, 1956/1992, p. 282). Diz Freud:

Por exemplo, o que um histérico expressa através de vômitos, um obsessivo expressará por meio de penosas medidas de proteção contra infecções, enquanto um parafrênico será levado a queixas ou suspeitas de estar sendo envenenado. Todas essas são representações diferentes do desejo de engravidar do paciente que foi reprimido para o inconsciente, ou de sua reação defensiva contra esse desejo. (Freud, 1913/1996, p. 180)

\subsection{Sintoma}

Nesta esclarecedora passagem, Freud nos apresenta o sintoma enquanto formação de compromisso entre forças recalcadoras e forças recalcadas. Tal como ocorre nos sonhos, o sintoma traz em si uma mensagem cifrada que pede decifração, leitura e interpretação. O sintoma pode ser entendido, portanto, como tudo aquilo que se expressa sob a via do disfarce, sendo passível de ser interpretado. Disfarce de um desejo inconsciente que, por ter sido rejeitado e excluído, só pode se apresentar através de uma máscara.

O sintoma seria, com efeito, aquilo que comparece no lugar de (substitui $=$ metáfora) um desejo recalcado, denunciando o fracasso da defesa e o temível retorno do recalcado. Aquilo que vaza e insiste, isso é o sintoma. Uma vez que é impossível falar do desejo, por este ser inconsciente, resta ao sintoma manifestar- 
se em seu lugar, através de um tipo de fala, ou melhor, um tipo de 'grito', que se expressa sob a via do disfarce e que, portanto, pede decifração. Há algo do desejo que, através do sintoma, esperneia e reclama por reconhecimento.

Ao mesmo tempo em que o sintoma mascara a verdade de um desejo (do qual o sujeito nada quer saber) ele também revela, de maneira disfarçada, a existência deste mesmo desejo, outrora recalcado. Pode-se dizer que o sintoma existe para que o desejo inconsciente possa ser reconhecido, legitimando assim o sujeito enquanto ser desejante. Ensina Lacan (1966/2008):

É numa memória (..), que jaz esta cadeia que insiste em se reproduzir na transferência, e que é a de um desejo morto. É a verdade do que esse desejo foi em sua história, que o sujeito grita pelo seu sintoma. (Lacan, 1966/2008, p. 249)

Para Lacan, o sintoma é uma metáfora e o desejo uma metonímia. Nessa direção, o sintoma pode ser pensado como solução de compromisso entre forças conflitantes, algo que aparece no lugar de um conflito (metáfora $=$ substituição), indicando a divisão subjetiva do sujeito. Enquanto metáfora, o sintoma somente pode ser entendido como um significante que vem no lugar de outro significante (recalcado), encobrindo um desejo do qual o sujeito nada quer saber. Em sua estrutura, o sintoma implica o sujeito do inconsciente estando, portanto, submetido às leis da linguagem. A respeito da formação do sintoma, Freud (1910[1909]/1996) escreve o seguinte:

A natureza dos desejos incompatíveis que, não obstante o recalque, continuam a dar sinal de si no inconsciente, e os elementos determinantes subjetivos e constitucionais que devem estar presentes em qualquer pessoa antes do malogro do recalque podem ocorrer e um substituto ou sintoma ser formado. (Freud, 1910[1909]/1996, p. 42)

Pode-se dizer que o sintoma presta-se a um modo de gozo para o sujeito, encobrindo um desejo do qual ele nada quer saber, ou seja, marcando a "presença de uma ausência”. O sintoma surge no lugar de um desejo que já não está mais ali, o qual Lacan chamou de "desejo morto" (1966/2008), ou, simplesmente, desejo recalcado. Sai o desejo (recalcado), entra o gozo (sintoma). Sobre a relação entre gozo e sintoma, Miller (2012) vai dizer o que segue: 
A repetição é o que merece ser chamado de sintoma, o que nos apresenta, efetivamente, uma repetição de gozo e, por isso mesmo, uma constância (...). O sintoma, tal como ele é tomado na última parte do ensino de Lacan, comporta, em si mesmo, o desenvolvimento temporal dessa relação com o gozo. (Miller, 2012, p. 35)

Gozo este que, segundo Miller (2011), não mente. Daí a importância de escutá-lo. A propósito, sobre a escuta e interpretação do sintoma - e do gozo que ele comporta -, pode-se dizer que se um sintoma é interpretável pelo Outro é porque ele porta não apenas uma mensagem para o Outro, mas também uma mensagem do Outro, levando-se em consideração o processo invertido da comunicação. Segundo Lacan (1953), o próprio sintoma, assim como o inconsciente, também estaria estruturado como uma linguagem. Uma linguagem cuja fala deve ser liberada. Vale observar que na clínica psicanalítica, o sujeito fala também através da linguagem dos sintomas que lhe acometem e não somente pelas palavras que enuncia.

Uma das principais características do gozo lacaniano é exatamente a mesma do sintoma: conjugar dor e prazer. Sendo o sintoma uma formação de compromisso entre prazer e sofrimento, pode-se dizer que o sujeito extrai gozo do sintoma. Há uma espécie de prazer dolorido, tanto no gozo como no sintoma. Vejamos como Valas (2001) conduz a questão:

no nível do consciente, o sujeito pode experimentar o seu sintoma como dor, mas não consegue destacar-se dele, porque, no nível do inconsciente, a pulsão encontra uma satisfação parcial. (Valas, 2001, p. 63)

Por outro lado, queixando-se do sintoma, o sujeito demanda reconhecimento - reconhecimento de um desejo - o que apontaria para sua existência enquanto ser desejante. O impasse surge na medida em que para o sujeito se colocar na posição de desejante, deve abrir mão de algo: deve renunciar uma parcela de gozo. $\mathrm{Ou}$ seja, há que se perder algo; e ninguém gosta de perder. Está aí presente o funcionamento de 'báscula' entre gozo e desejo: para se defender do desejo (do Outro) e da angústia que daí advém, o sujeito goza (no sintoma), da mesma forma 
que, para se defender do gozo (do sintoma), o sujeito parte em busca da verdade do seu desejo (análise).

\subsection{Fantasia}

Fantasia pode ser definida como a maneira pela qual cada um de nós, por meio de um cenário imaginário, dissolve ou encobre o impasse fundamental relacionado ao desejo do Outro ('Che vuoi?'). A falta no Outro (castração), ocasiona uma perda para o sujeito; perda esta que seria, precisamente, uma perda de gozo. A fantasia se instauraria, então, como uma contrapartida para este gozo que se perdeu, sendo, portanto, uma fantasia de completude.

Uma vez que algo falta ao Outro, este logicamente deseja. A fantasia também pode ser pensada como uma resposta-defesa a esse desejo enigmáticoameaçador do Outro. É o que propõe Rudge ao afirmar que "a fantasia é o que o sujeito oferece como resposta ao desejo do Outro, para não ter que responder a esse desejo com seu próprio "ser de objeto"” (Rudge, 2005, p. 86).

Um recurso defensivo de que o sujeito lança mão para velar/encobrir a castração, sempre angustiante - isso é fantasia. Vem daí a expressão 'lembrança encobridora' - encobridora da castração, isto é, da falta no Outro. O modo como o sujeito se defende da angústia (de castração) está diretamente relacionado às ideias de fantasia e estrutura clínica. Ambas são concebidas por Lacan como modos relativamente estáveis de defesa contra a castração. O que distinguiria cada estrutura clínica, portanto, seria o modo particular como o sujeito fantasia para velar a falta no Outro. As características singulares do cenário fantasmático do sujeito expressam, igualmente, o modo singular de cada um gozar - 'diga-me como fantasias (e gozas) e eu te direi quem és'. Sobre essa relação da fantasia com o gozo, Miller (2012, p. 34) diz o que segue: "pensar a relação com o gozo sob a forma da fantasia é pensar o obstáculo sob a forma de uma tela que se trata de atravessar". 
Lacan vai comparar a cena fantasmática a uma imagem congelada na tela do cinema, pouco antes de ser exibida uma cena mais forte (traumática). Viria daí as qualidades de fixidez e imobilidade associadas à fantasia. Articulando o que há de comum entre os conceitos de fantasia e fetiche, Lacan diz o seguinte:

Ela (cadeia da memória) se interrompe, com efeito, na barra do vestido, não acima do tornozelo, ali onde se encontra o sapato, e é por isso mesmo que este último pode, ao menos em alguns casos particulares, mas exemplares, assumir a função de substituto daquilo que não é visto. (Lacan, 1956-57/1995, p. 121)

Ou seja, o sujeito se agarra com unhas e dentes à fantasia/objeto-fetiche exatamente pelo fato destes terem lhe salvo do desamparo absoluto/da visão angustiante da falta no Outro (castração). Difícil pensar em melhor exemplo desta articulação fantasia/objeto-fetiche do que o da calcinha - objeto fetiche por excelência - em sua função de "véu" protetor/encobridor de uma falta.

Entretanto, nos breves momentos em que a fantasia se desfaz, aquilo que deveria ficar escondido se manifesta e o sujeito fica exposto ao que Freud chamou de 'estranho' ('unheimlich') e à angústia que advém daí. Articulando os conceitos de fantasia, estranho e angústia, Rudge (2005) diz o seguinte:

O breve momento em que a fantasia se desfaz, momento do estranho, é um momento de angústia porque provoca a oscilação das referências em que o sujeito costuma se apoiar (Rudge, 2005, p. 86)

A autora esclarece ainda que nesses momentos de queda da fantasia, ou seja, de estranhamento, ao contrário do que muitos autores erroneamente indicam, não é a angústia traumática que costuma aparecer, mas sim a angústia sinal. Sinal do temível retorno do recalcado.

A fantasia passa a ocupar, assim, um lugar central na vida do sujeito, estando por trás daquilo que chamamos de 'sintomas'. Em relação às formações sintomáticas, pode-se dizer que os sintomas surgiriam não a partir de fatos objetivos e concretos, mas a partir de uma dialética complexa na qual a fantasia exerceria um papel fundamental. Diz Lacan (1956-57/1995): 
Isso, que está excluído, que não está presente na neurose, mas cujas evoluções se manifestam, aliás, em todos os seus sintomas constitutivos, é reencontrado num elemento do quadro clínico que é a fantasia. (Lacan, 1956-57/1995, p. 120)

A fantasia apresenta, portanto, uma dupla face, pois, ao mesmo tempo em que serve como um anteparo de proteção contra a angústia, está por trás da produção patológica do sujeito (sintomas).

Uma das tarefas da análise seria, com efeito, a de ajudar o analisando a 'atravessar a fantasia' e, assim, reconhecer que o objeto perdido do desejo não é nada mais do que isso: uma falta, pura e simples. O objeto simplesmente está faltando - não foi roubado, nem perdido. Em outras palavras, o desejo nunca teve um objeto que pudesse perder. Desejo não é outra coisa senão desejo de falta, desejo pelo que está faltando - e sempre esteve. Ao propiciar ao analisando a travessia da sua fantasia fundamental, o dispositivo analítico produz uma modificação no modo de defesa do sujeito, uma alteração em seu modo de gozo.

\subsection{Angústia na clínica}

É respeitando a angústia como algo inerente ao humano e sinal daquilo que, do desejo e do gozo, revela-se como estranho ao eu, que podemos seguir na via inaugurada por Freud. Ou seja, prosseguir para além do objetivo terapêutico de alívio, apaziguamento. (Besset, 2002, p. 16)

O sofrimento de hoje está de certa forma atrelado a sintomas decorrentes de uma exigência de satisfação irrestrita, excessiva, e que, invariavelmente, remetem à angústia. Muitos sujeitos já chegam para análise com seu autodiagnóstico na ponta da língua: 'tenho síndrome do pânico, doutor'. O que seriam esses ataques de pânico, tão frequentes na atualidade, senão uma reação corporal, uma descarga no corpo, sem intermediação, de um excesso que estaria acima da capacidade do sujeito lidar? 'Pânico' nada mais seria, portanto, que um nome moderno, um 
rótulo atual, ou ainda uma 'nova roupagem' (Besset, 2002), conferido a algo que Freud e Lacan já estudavam profundamente há mais de meio século: angústia.

Na situação analítica, a angústia é o afeto por excelência, aquele que mais interessa aos psicanalistas. Ao funcionar como bússola de uma análise, a angústia indica o percurso do sujeito desde o gozo até o desejo (e vice-versa). Diz Rudge (2005):

É o retorno do "desejo enterrado" que é sinalizado com a angústia, e esse retorno é perigoso. Como em Freud, o que o sinal de angústia sinaliza é o retorno do recalcado: a irrupção do desejo recalcado, o desejo do Outro como desejo inconsciente (Rudge, 2005, p. 85).

Caberia aos analistas, portanto, estarem atentos a este precioso instrumento de orientação - a angústia - para fins de "sentir o que o sujeito pode suportar de angústia" (Lacan, 1962-63/2005, p. 13). Esta modulação da angústia do analisando é o que vai definir o sucesso de uma análise, uma vez que sendo a angústia necessária para toda análise, ela o é desde que dentro de um nível suportável pelo sujeito. Isto, segundo Lacan, é o que poria os analistas à prova a todo instante.

As estruturas clínicas seriam, como vimos, modos de defesa relativamente estáveis contra a angústia. A fobia de Hans, por exemplo, pode ser vista como a forma que o menino encontrou para se defender da angústia causada, nesse caso, não pela castração, mas pela ausência de castração (falta de falta) e também pela ambivalência (amor/ódio) em relação ao pai. Acting out e passagem ao ato, também representam, de maneira radical, outras formas de defesa contra a angústia. Acompanhemos Freud (1926[1925]/1996) nesta passagem esclarecedora que articula o papel determinante da angústia nas diferentes estruturas:

Afigura-se provável que, como um determinante da angústia, a perda do amor desempenha o mesmíssimo papel na histeria que a ameaça de castração nas fobias e o medo do superego na neurose obsessiva. (Freud, 1926[1925]/1996, p. 141)

Ou seja, "perda do amor", "ameaça de castração" e "medo do superego" teriam como determinante comum, segundo Freud, a angústia, contra a qual cada 
sujeito se defende como pode. Histeria, fobia e neurose obsessiva são algumas dessas possibilidades de defesa, citadas por Freud. Articulando angústia e sintoma obsessivo, Besset (2002) afirma que "o sintoma obsessivo, que evita a angústia pelo viés do 'psíquico', presentifica uma satisfação pulsional difícil de ser abandonada pelo sujeito" (Besset, 2002, p. 19).

\subsection{Gozo na clínica}

Considerando que há, como vimos, uma espécie de decadência do gozo fálico (intrinsecamente regulado) na atualidade e um outro gozo em ascensão, também precisam ser pensados de maneira diferente a clínica e o sujeito que demanda análise. O gozo intrinsecamente limitado de outrora cede lugar a este outro gozo, sem ponto de ancoragem e, portanto, ilimitado. Como se a transgressão do gozo estivesse cedendo lugar à obrigação de gozar - 'Goza'! 'A qualquer preço'! É o que ordena o supereu e, como vimos, também a cultura.

O que pode ser feito, portanto? De que recursos o analista disporia para lidar com isso que é da ordem do ilimitado e do indizível? Parodiando o poeta, Besset (2002) indica que diante de um analisando que não demanda falar para construir um saber, inventar, tanto quanto navegar, "é preciso".

Uma das propostas com a qual simpatizamos seria a do 'acolhimento do gozo na clínica', como defende Rozenthal (2009). Acolher o gozo significa dizer que o setting analítico não deveria ser campo de batalha entre gozo e desejo, mas um local privilegiado de produção de novas possibilidades de gozo. Acolher o gozo significa identificar nele uma força capaz de impulsionar, por mais paradoxal que seja, o próprio desejo do analisando. Acolher o gozo pode nos remeter também à ideia de uma gestação. Ou seja, acolher com a finalidade de gestar... novos modos de gozo na clínica.

Acolher o gozo na clínica significa também acolher aquilo que se repete, ou seja, o sintoma do analisando. O analista deve escutar o sintoma, deixá-lo falar, ou 
melhor, gritar. Dar voz ao sintoma seria justamente dar importância àquilo que é, aparentemente, sem sentido, que 'não serve pra nada', que é desperdício, pura perda de tempo e energia, mas que, apesar disso tudo, tem uma função importantíssima para o sujeito. Calar o sintoma, seja através de medicamentos ou 'psicoterapias apaziguadoras', significa calar o sujeito, e o desejo que, através do sintoma, dá sinal de vida.

A ideia de um 'gozo impulsionador do desejo', ou simplesmente 'gozo produtivo', ou ainda um 'gozo contíguo ao desejo' (e não em oposição) advém tanto da minha experiência clínica como também de exemplos da nossa cultura, dos quais passo a listar alguns:

1) A utilização intensa de tabaco por Freud, que funcionou, não como obstáculo, mas como potente motor propulsor de suas pesquisas, do seu trabalho e da sua produção;

2) Um sujeito obsessivo que coloca parte do gozo que obtém com organização e controle à serviço do seu trabalho como responsável pelo setor de "auditoria/controles internos" da empresa onde atua;

3) A relação que o músico Bob Marley estabeleceu com a maconha, que, ao invés de representar um obstáculo, na verdade, servia de fonte impulsionadora e inspiradora da sua produção;

4) Um ator de teatro que colocou seu diagnóstico de "hiperatividade" à serviço do seu trabalho, fazendo sucesso com uma peça cujo título enaltece justamente seu sintoma;

Estes são alguns exemplos de gozo contíguo ao desejo - um gozo impulsionador da produção e do desejo. Ou seja, o gozo pode sim estar a serviço do desejo, ser um facilitador do desejo, e não apenas um 'obstáculo', como costuma ser (mal) entendido. Nesta visada, o gozo deixa de ser percebido como desestabilizador e causador de perturbações, e passa a ser encarado como um poderoso recurso para lidar com os excessos que ameaçam inundar o psiquismo. Eis a vertente estabilizadora e apaziguadora do gozo. 
Para ilustrar a proposta de manejo, de como lidar com este excesso/gozo que insiste em se apresentar na clínica, façamos uso de uma metáfora já utilizada por Lacan em seu livro "Televisão" (1974/1993, p. 38), a metáfora da usina hidrelétrica. Abordaremos esta metáfora a partir de outro viés, no intuito de demonstrar a importância do manejo dos excessos do aparelho psíquico, assim como do nível da água em uma represa. Encontramos respaldo para esta empreitada nas seguintes palavras de Fenichel (1972):

(...) the decisive state of tension forming the basis of a neuroses can be brought about by too much influx as well as by too little discharge. (...) If, on the other hand, discharges are blocked, a little influx, otherwise harmless, may have the effect of one much more intense, creating a flooding. ${ }^{22}$

Não precisamos ser engenheiros elétricos, ou coisa parecida, para termos alguma ideia de qual seja o pré-requisito fundamental para que haja geração de energia em uma usina hidrelétrica, qual seja, o represamento das águas de um rio. Pode-se dizer então que se não houver uma barreira, algo que promova uma contenção, uma certa resistência à correnteza do rio, é impossível a geração de energia. Pois bem, uma vez represada a água, surge a necessidade de gerenciar seu nível na represa.

Dependendo do nível da água, quando ocorre um excesso (excesso de chuvas na cabeceira do rio, por exemplo), também não é necessário sermos especialistas no assunto para sabermos da necessidade de se verter água $($ vertimento $=$ desperdício $=$ perda $=$ gozo $)$, de se abrir as comportas da represa, antes que ocorra um transbordamento, ou seja, a temível inundação. Verter a água da represa é um 'desperdício' na medida em que se trata de um recurso valioso (água) que poderia passar pela turbina e gerar energia, mas que, para se evitar o pior (transbordamento), precisa ser desperdiçada (vertida). A comparação com o gozo aqui é inevitável: ou o sujeito goza, ou pior. Diz Lacan: "Essa entropia, esse ponto de perda, é o único ponto, o único ponto regular por onde temos acesso ao que está em jogo no gozo" (1970/1992, p. 53). Entropia aqui deve ser entendida como uma forma de mensuração da parcela de energia que não pode mais ser

\footnotetext{
${ }^{22}$ o estado de tensão determinante que constitui a base de uma neurose pode ser provocado por um afluxo excessivo, bem como por uma descarga insuficiente. (...) Se, por outro lado, as descargas são bloqueadas, um afluxo pequeno, de outro modo inofensivo, pode ter o efeito de um muito mais intenso, criando uma inundação.
} 
transformada em trabalho. Por outro lado, em épocas de escassez de chuva, há que se reter água (demarcação do gozo), sob o risco do nível dos reservatórios abaixarem muito, podendo causar a interrupção do fornecimento de energia e ainda possíveis danos às turbinas (ou ao corpo, no caso do gozo desmedido).

\subsection{Fim de Análise}

O fim da análise, em Lacan, concerne sempre à relação do sujeito com o gozo e à modificação que pode ser feita nisso. (Miller, 2012, p. 34)

Na construção destes novos modos de gozo com o analisando, há que se considerar a questão da potência do gozo fálico, gozo seguro, intrinsecamente limitado, contíguo ao desejo, que permite ao sujeito continuar gozando no dia seguinte, com "a convicção de que, mesmo indo muito longe, poderá disputar o próximo campeonato" (Vieira 2008, p. 91). Na pena do mestre temos o que segue:

O trabalho psicanalítico continuamente se defronta com a tarefa de induzir o paciente a renunciar a uma dose imediata e diretamente atingível de prazer. Não se pede a ele que renuncie a todo prazer; talvez não se possa esperar isso de nenhum ser humano, e até mesmo a religião é obrigada a apoiar sua exigência de que o prazer terreno seja posto de lado prometendo proporcionar em seu lugar uma quantidade incomparavelmente maior de um prazer superior no outro mundo. Não, apenas se pede ao paciente que renuncie às satisfações que inevitavelmente trarão consequências prejudiciais. (Freud, 1916/1996, p. 326)

Do que Freud está falando aqui, apesar de não mencionar o gozo tal como concebido por Lacan, senão das ideias de acolhimento do gozo na clínica e de um gozo seguro? Não se trata de proibir o gozo, mas de autorizar o analisando a não gozar (desobrigar-se); ou, melhor, a gozar de outros modos. Trabalhar com o analisando formas criativas e singulares de libertá-lo da relação de servidão com o supereu, que o submete ao seu imperativo categórico de gozo. Desta maneira o gozo torna-se uma ilusão de liberdade (transgressão), mas que na verdade é escravidão (p. ex drogadição). A análise buscaria, portanto, suscitar o sujeito da escolha. Sem alterar a relação do sujeito com o gozo não há final de análise. 
Uma análise chega ao fim quando o discurso de um sujeito, necessariamente articulado com a falta, cessa de buscar no Outro algo que possa preenchê-la, explicá-la ou justificá-la. Um analisando se torna analista ao assumir que seu desejo não precisa apoiar-se no Outro; que a autorização do seu desejo pode vir somente de si mesmo. Ou seja, quando se torna capaz de responsabilizar-se pelo seu desejo.

O fim da análise de um sujeito neurótico implicaria, portanto, em restituirlhe o acesso aos polos tanto do gozo como do desejo, dos quais ele, por uma razão ou outra, se defende. Com a 'travessia da fantasia', o sujeito torna-se capaz de modificar seus modos de defesa e seus modos de gozo, podendo então nomear e reconhecer seu desejo, trazendo-o à existência. 


\section{Considerações Finais}

Entre os dois, entre gozo e desejo é que se joga a totalidade da experiência subjetiva. Em ambos os casos trata-se de um sujeito imerso nas redes da linguagem, cindido e separado do objeto que é causa de seu desejo e evocador do gozo proibido. (Braunstein, 2007)

Há algo para além da visão maniqueísta e beligerante quando o assunto é gozo e desejo. Propusemo-nos pensar, ao longo deste trabalho de pesquisa, gozo e desejo de forma contígua, ou seja, lado-a-lado, um alimentando o outro, de forma que se reconheça a importância de ambos para o equilíbrio psíquico do sujeito. $\mathrm{O}$ que buscamos destacar é que o desejo pode ser visto também como impulsionador, pré-condição, uma espécie de 'abre-alas' do gozo, uma vez que é preciso que haja lei (desejo) para haver transgressão (gozo). É o desejo percebido não apenas como barreira, mas também como condição do gozo. E, vice-versa, também é preciso que haja a vontade de transgressão (gozo) para que a lei (desejo) exista.

Apresentamos a ideia do manejo do gozo na clínica não como uma espécie de campo de batalha entre gozo e desejo, de combate ao gozo, de forma que atacando-se o gozo possa cessar o sofrimento do sujeito e, finalmente, possibilitar que seu desejo advenha; mas sim, uma clínica analítica que possa ser capaz de acolher o gozo. Ou seja, o setting analítico pensado como um lugar privilegiado de criação conjunta analista-analisando daquilo que podemos chamar de 'espaço seguro para o gozo'. Vimos a importância de se trabalhar com o analisando novas possibilidades, criativas e seguras, de gozar, de verter os excessos que ameaçam inundar seu aparelho psíquico, prevenindo o temível transbordamento. Uma espécie de inundação controlada. Para ilustrar, empreendemos uma comparação com o funcionamento de uma usina hidrelétrica, dando ênfase à necessidade de se verter água quando há, por exemplo, um excesso de chuvas. Ou verte-se água (perda $=$ desperdício), ou pior .

Tomando como base que a clínica psicanalítica será movimentada pelo inconsciente, isto é, pelo gozo e pelo desejo, o que se visa é transformar o sujeito 
nas suas relações com o gozo, que se apresenta perturbador. Do gozo impossível ao desejo submetido à lei, eis um dos possíveis percursos de uma análise. Cito Braunstein (2007):

Pois é a instância analítica que permite levar o sujeito a confrontar-se com seu desejo, momento em que a experiência deverá ser interrompida para permitir ao sujeito procurar os caminhos pelos quais poderá transitar para que seu desejo abra caminho ao gozo. (Braunstein, 2007, p. 171)

A nosso ver, exatamente por sua singularidade, e pelo fato de que não mente, é que o gozo deve ocupar lugar privilegiado na clínica psicanalítica, clínica do singular por excelência - 'Diga-me como gozas e eu te direi quem és'. Sobre o modo singular de cada um gozar e o quanto isso diz sobre o sujeito, Miller (2011) esclarece o seguinte:

Freud indica como o sintoma é arrastado para a homeostase do sujeito, ou seja, faz parte de sua maneira de ser cuja mola é seu modo de gozar. (...) modo singular de um sujeito gozar, modo de gozar apreendido em seu funcionamento positivo. (Miller, 2011, p. 70)

Um pouco mais adiante, no mesmo texto, o autor vai destacar outra valiosa característica do gozo ao dizer que "há uma verdade mentirosa do desejo, ao passo que (...) o gozo não mente" (Miller, 2011, p. 195). Ou seja, há que se escutar atentamente o gozo do analisando se quisermos nos manter na direção certa da cura e da verdade do sujeito que nos fala.

Portanto, tanto o gozo, como a obra de arte, servem sim, e para muita coisa! Como nos lembra Miller (2012), não é preciso muito esforço para perceber os efeitos reconfortantes de uma obra de arte sobre os sujeitos, e o preço que se paga por elas é a maior prova deste inestimável efeito que proporciona. Da mesma forma, buscamos demonstrar que o valor do gozo reside em seus efeitos reconfortantes e estabilizadores para o sujeito, que também precisa, invariavelmente, pagar um preço para obtê-lo. O exemplo que vimos do famoso e singular jogo do 'fort-da' - utilizado pelo neto de Freud como um interessante recurso para lidar com a presença-ausência da mãe - ilustra bem isto que é aparentemente sem valor e 'non-sense', porém cuja função é de grande valia para 
o sujeito. Quem vê de longe a criança entretida naquele jogo aparentemente inútil, repetitivo, sem sentido, algo que parece total perda de tempo e de energia (jogar e puxar um carretel repetidas vezes, que idiotice!), não percebe o valor que esse ritual - que mistura "dor e prazer" e aparentemente "não serve para nada" (duas das principais características do gozo) - tem para o menino.

Desta maneira, o inocente 'fort-da' ao mesmo tempo em que funciona como um poderoso recurso de simbolização, serviria também como meio de gozo; um gozo que visaria à estabilização. No sexto paradigma do gozo, conforme estabelecido por Miller (2012), vemos esta concepção de gozo articulada à sublimação. Vamos ao texto: "Lacan indica-nos, verdadeiramente, que é no lugar do gozo Uno que a sublimação encontra seu verdadeiro fundamento". (Miller, 2012, p. 46). Sublimação esta que não implica o Outro, que é solitária, assim como em nosso exemplo do 'fort-da'. Ao longo dos capítulos, nosso olhar se voltou para esta função importantíssima do gozo no equilíbrio psíquico: a de lidar com os excessos que ameaçam inundar o psiquismo.

Percorremos também os caminhos enigmáticos do desejo no intuito de demonstrar como o desejo vai muito além das necessidades, uma vez que, não se dirige a objetos predeterminados nem se submete à herança natural. Pelo contrário, empreendemos um percurso teórico no intuito de demonstrar como o desejo se articula à linguagem como efeito desta, uma vez que só é possível ao sujeito desejar a partir de sua entrada na linguagem. O que estaria em questão em uma análise, portanto, não seriam as características psicológicas do sujeito, mas aquilo que pode ser trabalhado a partir da sua experiência de fala. Cada sujeito faz sua entrada na linguagem de maneira singular, e, portanto, goza e deseja de maneiras também singulares.

Vimos ainda, com apoio da 'fábula do louva-a-deus gigante' (Lacan, 196263/2005), como se dá a estreita ligação proposta por Lacan entre o fenômeno da angústia e o desejo do Outro. Angústia diante de um Outro, que se apresenta, ao mesmo tempo, como enigmático e assustador, e de quem eu não tenho a menor ideia do que quer e, principalmente, do que quer de mim. Lacan, em seu fiel retorno à letra freudiana, eleva o conceito de angústia ao status de único afeto que não engana, enquanto Miller vai compará-la com uma "bússola”, cuja função 
seria a de orientar o analista no percurso de uma análise; e todo caminhante sabe da importância que uma bússola tem em uma jornada. A angústia, com Lacan, passa a ser pensada como este intervalo, marcando a passagem do gozo ao desejo, e vice-versa.

Os paradoxos, as ambiguidades e ambivalências permeiam tanto a teoria quanto a clinica psicanalítica, e não seria diferente quando o assunto é gozo e desejo. Pensemos em alguns exemplos: ao mesmo tempo em que a resistência encobre, ela também revela. A transferência pode ser tanto positiva como negativa; pode funcionar tanto como motor de uma análise, como também pode emperrá-la, quando a serviço da resistência. Amor e ódio ( 'amódio') em relação ao pai, em relação à mãe, em relação ao irmãozinho(a). Um dos principais paradoxos do gozo que vimos no decorrer do trabalho concerne ao fato de que este, frequentemente associado ao desequilíbrio psíquico, e portanto combatido em algumas abordagens clínicas, também pode ter uma função estabilizadora e apaziguadora para o sujeito. Pode ser tanto condição de vida, como veículo para a morte e destruição.

Outro importante paradoxo do gozo, conforme proposto por Cottet (1989), também foi objeto de nossas considerações. Eis o paradoxo: o assassinato do pai da horda primeva de Totem e Tabu não somente vai abrir caminho para o gozo de seus filhos, como também reforça a proibição. Ou seja, a transgressão da lei além de não liberar o desejo, ainda vai reforçar a inibição e a interdição. Sobre esta aparente contradição, Vieira acrescenta outra, ao afirmar que "Freud demonstra como a renúncia ao gozo alimenta o gozo da renúncia" (Vieira, 2008, p. 89). Lacan (2009) nos ajuda a entender tais paradoxos do gozo abordando-os de uma só vez com extrema clareza:

Freud escribe El malestar en la cultura para decirnos que todo lo que del goce se gira hacia la interdicción se dirige en dirección a un reforzamiento siempre creciente de la interdicción. Cualquiera que se dedique a someterse a la ley moral ve siempre reforzarse las exigencias siempre más minuciosas, más crueles, de su superyo. $^{23}$ (Lacan, 1959-60/2009, p. 214)

\footnotetext{
${ }^{23}$ Freud escreve o Mal-estar na civilização para nos dizer que tudo que do gozo está ligado à interdição se dirige a um reforço sempre crescente da interdição. Qualquer pessoa que se dedique a submeter-se à lei moral vê sempre reforçar-se as exigências sempre mais minuciosas, mais cruéis, do seu supereu.
} 
Passando à investigação de alguns fenômenos culturais, nos propusemos articular estes com os conceitos psicanalíticos estudados. Nesta empreitada, pudemos perceber como a chamada 'sociedade do excesso' ou 'sociedade do gozo' ilustra bem o fenômeno atual de um 'não querer saber da falta' e 'ir além dos limites'. Este mesmo excesso presente na cultura é também uma das características mais marcantes do conceito psicanalítico de gozo - pura expressão de um excedente com o qual o sujeito é impelido a lidar.

O desenvolvimento do trabalho foi pensado de forma que os conceitos de gozo e desejo pudessem ser apresentados e discutidos, sempre que possível, ladoa-lado; não de forma separada, mas contígua. Diz o mestre francês: “A castração significa que é preciso que o gozo seja recusado, para que possa ser atingido na escala invertida da Lei do desejo." (Lacan, 1966[1960]/1998, p. 841). Ou seja, gozo e desejo tratados de maneira entrelaçada e articulada, exatamente como Lacan propõe ao formular sua escala ('échelle') invertida da lei do desejo; como se gozo e desejo fossem dois lados de uma mesma escada ('échelle'), sendo cada um deles fundamental para que a escada permaneça de pé. 


\section{Referências Bibliográficas}

AMBERTÍN, M. G. Ley, culpa y clandestinidades en el amor. In Tempo Psicanalítico, Rio de Janeiro, v. 43.1, p. 59-70, 2011.

ANDRÉ, S. O que quer uma mulher? Rio de Janeiro: Zahar, 1998.

BADIOU, A. Para uma nova teoria do sujeito. Rio de Janeiro: RelumeDumará, 1994.

BAREMBLITT, G. Compêndio de Análise Institucional. Rio de Janeiro: 3a. ed., Rosa dos Tempos, 1996.

BESSET, V. L. (Org.). Angústia. São Paulo: Escuta, 2002.

BIAGGIO, M. Del estrago al sintoma - una apuesta clínica - Buenos Aires: Grama ediciones, 2012.

BIRMAN, J. Mal-estar na atualidade: a psicanálise e as novas formas de subjetivação - $2^{a}$ ed. - Rio de Janeiro: Civilização Brasileira, 2000.

BRAUNSTEIN, N. Gozo. São Paulo: Escuta, 2007.

Desire and jouissance in the teachings of Lacan. In The Cambridge Companion to Lacan (Cambridge). Cambridge University Press, p. 102-115, 2003.

CLAVREUl, J. et al. O desejo e a perversão. Campinas: Papirus, 1990.

COELHO DOS SANTOS, T. Sobre a clínica da psicanálise de orientação lacaniana: dos impasses da sexuação à invenção do parceiro-sinthoma. In Ágora (Rio J.) [online]. v. XII, n.1, p. 9-26, 2009.

COELHO DOS SANTOS, T.; ZEITOUNE, C. Amor, impasses da sexuação e ato infracional na adolescência. In Tempo Psicanalítico, Rio de Janeiro, v. 43.1, p. 85-108, 2011.

COTTET, S. O paradoxo do gozo. Salvador: Fator, 1989.

COUTO, L. F. S. Uma classificação dos sentidos do termo gozo em Freud. In Estudos de Psicologia, 11(2), 179-190, 2006.

DELEUZE, G. O abecedário de Gilles Deleuze - B de Beber. Paris: Éditions Montparnasse, 1988-1989.

DOR, J. Introdução à leitura de Lacan: o inconsciente estruturado como linguagem. Porto Alegre: Artes Médicas, 1989.

FENICHEL, O. The Psychoanalytic Theory of Neurosis. New York: W.W. Norton \& Company Inc., 1972. 
FORTES, I. A dor psíquica. Rio de Janeiro: Cia. de Freud, 2012.

FREITAS, A. L.; RUDGE, A. M. O supereu entre o amor e o gozo. In Tempo Psicanalítico, Rio de Janeiro, v. 43.ii, p. 243-267, 2011.

FREUD, S. Obras Psicológicas Completas - Edição Standard Brasileira - $3^{\text {a }}$ ed. - Rio de Janeiro: Imago, 1996.

. (1894) Rascunho E. Como se Origina a Angústia. Vol. I.

. (1895) Projeto para uma Psicologia Científica. Vol. I.

. (1900) A Interpretação dos Sonhos (I). Vol. IV.

Vol. V. . (1900-01) A Interpretação dos Sonhos (II) e Sobre os Sonhos.

. (1905) Um Caso de Histeria, Três Ensaios sobre Sexualidade e outros trabalhos. Vol. VII (1912-13) Totem e Tabu. Vol. XIII (1915-16) Sobre a Transitoriedade. Vol. XIV . (1920) Além do Princípio de Prazer. Vol. XVIII. (1921) Psicologia de Grupo e a Análise do Eu. Vol. XVIII. (1923) O Ego e o Id. Vol. XIX. . (1926) Inibições, Sintomas e Angústia. Vol. XX. . (1929-30) O Mal-Estar na Civilização. Vol. XXI.

GARCIA-ROZA, L. A. Acaso e repetição em psicanálise: uma introdução à teoria das pulsões - Rio de Janeiro: Zahar. 1986.

Zahar. 2000. . Freud e o inconsciente. $17^{\mathrm{a}}$ ed. - Rio de Janeiro: Janeiro: Zahar. 2002. Introdução à metapsicologia freudiana; v.2 - Rio de

GUATIMOSIM, B. Amor, desejo e gozo na função analítica. In Stylus. Revista de Psicanálise (Rio de Janeiro), n 14, p. 115-124, 2007.

INCB - International Narcotics Control Board. Report of the International Narcotics Control Board for 2010 - disponível em http://www.incb.org/incb/en/publications/annual-reports/annual-report2010.html

JONES, E. The early development of female sexuality. In International Journal of Psychoanalysis. Vol. VIII, p. 459-472, 1927.

(1931) On the Nightmare, New York: Liveright, 1971

JORGE, M. A. C. A travessia da fantasia na neurose e na perversão trabalho apresentado no XIII Fórum Internacional de Psicanálise - Belo Horizonte - 24 a 28 de Agosto de 2004. Texto estabelecido, a partir da exposição oral, por Alexandre Louzada. 
KOJÈVE, A. (1947) Introduction to the reading of Hegel. New York: Cornell University Press, 1980.

LACAN, J. (1953-54) O Seminário. Livro 1: Os escritos técnicos de Freud. Rio de Janeiro: Zahar, 2009.

(1954-55) O Seminário. Livro 2: O eu na teoria de Freud e na técnica da psicanálise. Rio de Janeiro: Zahar, 2010.

Zahar, 1992.

(1955-56) O Seminário. Livro 3: As psicoses. Rio de Janeiro:

. (1956-57) O Seminário. Livro 4: A relação de objeto. Rio de Janeiro: Zahar, 1995.

(1957-58) O Seminário. Livro 5: As formações do inconsciente. Rio de Janeiro: Zahar, 1999. . (1959-60) El Seminario. Libro 7: La etica del psicoanálisis. Buenos Aires: Paidós, 2009.

. (1960-61) O Seminário. Livro 8: A transferência. Rio de Janeiro: Zahar, 1992.

Zahar, 2005.

(1962-63) O Seminário. Livro 10: A angústia. Rio de Janeiro:

(1964) O Seminário. Livro 11: Os quatro conceitos fundamentais da psicanálise. Rio de Janeiro: Zahar, 2008.

. (1966) Escritos. Rio de Janeiro: Zahar, 1998.

. (1966) Escritos. São Paulo: Perspectiva, 2008.

. (1969-70) O Seminário. Livro 17: O avesso da psicanálise. Rio de Janeiro: Zahar, 1992.

Zahar, 1985.

(1972-73) O Seminário. Livro 20: Mais, ainda. Rio de Janeiro:

(1974) Televisão. Rio de Janeiro: Zahar, 1993.

(1974-75) Seminar XXII: R.S.I. Text established by JacquesAlain Miller. Translated by Jack W. Stone, with the assistance of Ellie Ragland, Greg Hyder, Filip Kovacevic, and Zak Watson.

LAPLANCHE, J. Vocabulário da Psicanálise / Laplanche e Pontalis. $4^{\mathrm{a}}$ ed. São Paulo: Martins Fontes, 2001.

MARTINS, V. T. O recurso à droga nas psicoses: entre objeto e significante. Tese (Doutorado). Rio de Janeiro: UFRJ/IP. Orientadora: Angélica Bastos Grimberg., 2009.

MASTERS, W. H.; JOHNSON, V. E. (1966). Human Sexual Response. Toronto; New York: Bantam Books, 1981.

MAUSS, M. (1923-24). Ensaio sobre a dádiva. Forma e razão da troca nas sociedades arcaicas. In : Sociologia e Antropologia. v. II - São Paulo: Edusp, 1974. 
MELMAN, C. O homem sem gravidade: gozar a qualquer preço. Rio de Janeiro: Cia. de Freud, 2003.

MILLER, J.-A. Percurso de Lacan: uma introdução. Rio de Janeiro: Zahar, 1988.

Lacan elucidado: palestras no Brasil. Rio de Janeiro: Zahar, 1997.

Silet: os paradoxos da pulsão, de Freud a Lacan. Rio de Janeiro: Zahar, 2005.

. La angustia lacaniana. Buenos Aires: Paidós, 2007.

Paidós, 2010.

Conferencias porteñas: tomo I. Desde Lacan. Buenos Aires:

Janeiro: Zahar, 2011.

Os seis paradigmas do gozo. In: Opção Lacaniana online nova série. Ano 3 - Nr. 7, 2012.

ROUDINESCO, E. Dicionário de psicanálise/Elisabeth Roudinesco, Michel Plon. Rio de Janeiro: Zahar, 1998.

ROZENTHAL, E. "Cuidado de si e cuidado do outro: sobre Foucault e a psicanálise”. In: Maia, M. S. (org.), Por uma ética do cuidado. Rio de Janeiro: Garamond, 2009.

RUDGE, A. M. Pulsão e linguagem: esboço de uma concepção psicanalítica do ato. Rio de Janeiro: Zahar, 1998.

As fantasias oníricas, para que servem? In Psychê,

Universidade de São Marcos, São Paulo, p. 63-72, 1999.

. Jones e Lacan: pesadelos, demônios e angústia. In

Pulsional, São Paulo, v. XVII, p. 80-87, 2005.

. Pulsão de morte como efeito de supereu. In Ágora

(PPGTP/UFRJ). Rio de Janeiro, v. IX, n. 1, p. 79-90, 2006.

. Trauma. Rio de Janeiro: Zahar, 2009.

SADE, M. A filosofia na alcova. São Paulo: Iluminuras, 2008.

SALAMONE, L. D. Alcohol, tabaco y otros vícios. Buenos Aires: Grama Ediciones, 2012.

VALAS, P. As dimensões do gozo: do mito da pulsão à deriva do gozo. Rio de Janeiro: Zahar, 2001.

VIEIRA, M. A. O lugar da psicanálise na medicina - introdução à uma conferência de Jacques Lacan, Cadernos do IPUB, vol. VIII, n. 21 (Ciência e saber no campo da saúde mental), p. 115-122, 2002. 
Restos: uma introdução lacaniana ao objeto da psicanálise. Rio de Janeiro: Contra Capa, 2008.

Mães Lacanianas. Comunicação verbal na Escola Brasileira de Psicanálise (EBP) em 06/10/11. Rio de Janeiro, 2011.

ZIMERMAN, D. Vocabulário contemporâneo de psicanálise. Porto Alegre: Artmed, 2001. 